
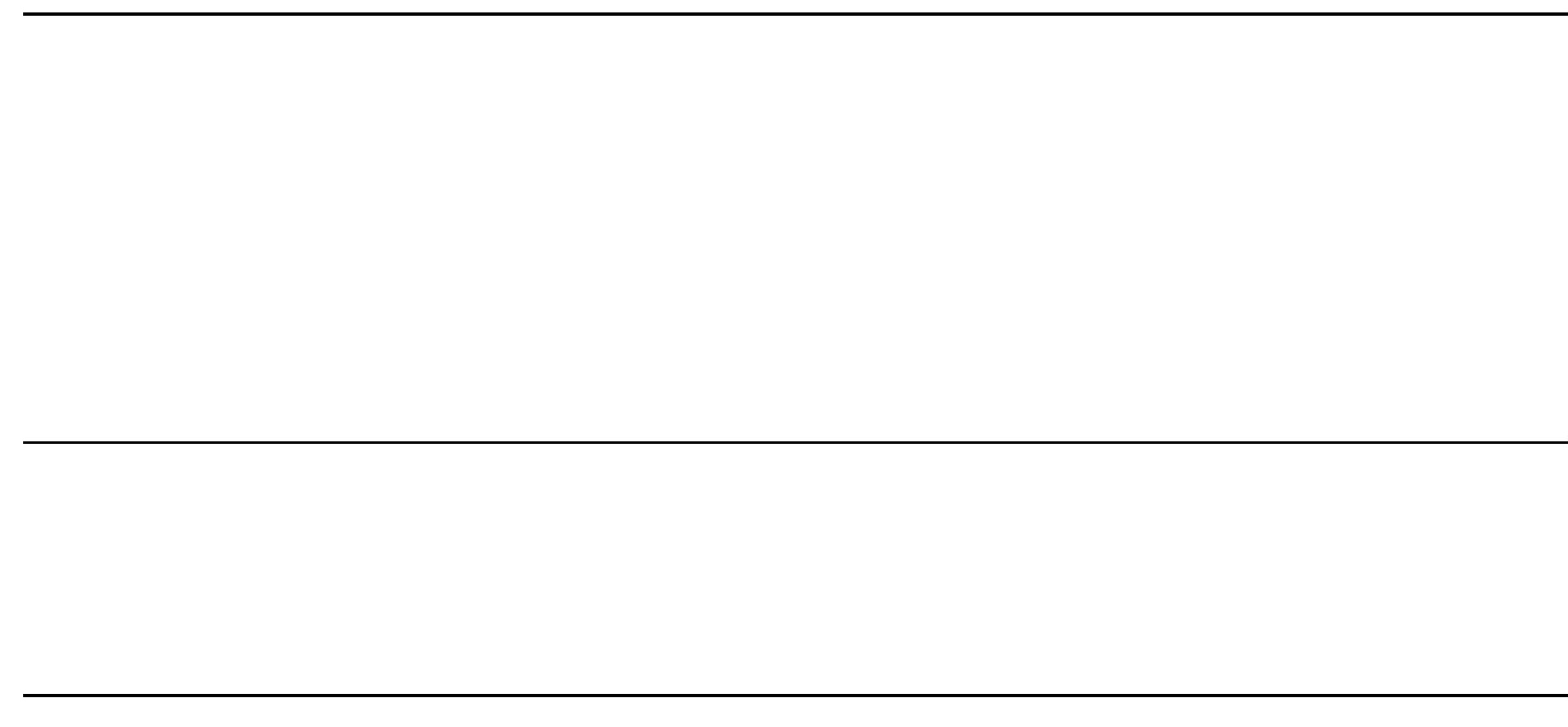


\section{An optimised series of substituted $N$ - phenylpyrrolamides as DNA gyrase B inhibitors}

Davide Benedetto Tiz a , Žiga Skok a , Martina Durcik a , Tihomir Tomaši ، a , Lucija Peterlin Maši ، a, Janez Ilaš a , Anamarija Zega a , Gábor Draskovits ${ }^{\mathrm{b}}$, Tamás Révész ${ }^{\mathrm{b}}$, Ákos Nyerges ${ }^{\mathrm{b}}$, Csaba Pál $^{\mathrm{c}}$, Cristina D. Cruz ${ }^{\mathrm{c}}$, Päivi Tammela ${ }^{\mathrm{c}}$, Dušan Žigon ${ }^{\mathrm{d}}$, Danijel Kikelj ${ }^{\mathrm{a}}$, Nace Zidar ${ }^{\mathrm{a}}{ }^{*}$

${ }^{a}$ Faculty of Pharmacy, University of Ljubljana, Ašker eva cesta 7, 1000 Ljubljana, Slovenia

${ }^{b}$ Synthetic and Systems Biology Unit, Institute of Biochemistry, Biological Research Centre of the Hungarian Academy of Sciences, Szeged H-6726, Hungary

${ }^{c}$ Drug Research Program, Division of Pharmaceutical Biosciences, Faculty of Pharmacy, University of Helsinki, P.O. Box 56 (Viikinkaari 5 E), Helsinki FI-00014, Finland

${ }^{d}$ Jožef Stefan Institute, Department of Environmental Science, Jamova cesta 39, 1000 Ljubljana, Slovenia

\section{ABSTRACT}

ATP competitive inhibitors of DNA gyrase and topoisomerase IV have great therapeutic potential, but none of the described synthetic compounds has so far reached the market. To optimise the activities and physicochemical properties of our previously reported $N$-phenylpyrrolamide inhibitors, we have synthesised an improved, chemically variegated selection of compounds and evaluated them against DNA gyrase and topoisomerase IV enzymes, and against selected Grampositive and Gram-negative bacteria. The most potent compound displayed $\mathrm{IC}_{50}$ values of $6.9 \mathrm{nM}$ against Escherichia coli DNA gyrase and 960 nM against Staphylococcus aureus topoisomerase IV. Several compounds displayed minimum inhibitory concentrations (MICs) against Grampositive strains in the 1-50 $\mu \mathrm{M}$ range, one of which inhibited the growth of Enterococcus faecalis, Enterococcus faecium, S. aureus and Streptococcus pyogenes with MIC values of $1.56 \mu \mathrm{M}, 1.56$ $\mu \mathrm{M}, 0.78 \mu \mathrm{M}$ and $0.72 \mu \mathrm{M}$, respectively. This compound has been investigated further on methicillin-resistant $S$. aureus (MRSA) and on ciprofloxacin non-susceptible and extremely drug resistant strain of $S$. aureus (MRSA VISA). It exhibited the MIC value of $2.5 \mu \mathrm{M}$ on both strains, 
and MIC value of $32 \mu \mathrm{M}$ against MRSA in the presence of inactivated human blood serum. Further studies are needed to confirm its mode of action.

KEYWORDS: antibacterial; ATP competitive; DNA gyrase; GyrB; inhibitor; $N$ phenylpyrrolamide; ParE; topoisomerase IV

\section{ABBREVIATIONS}

ACN, acetonitrile; ATCC, American type culture collection; ATR, attenuated total reflectance; CFU, colony-forming unit; CLSI, Clinical and Laboratory Standards Institute; DCM, dichloromethane; DMF, dimethylformamide; DIAD, diisopropylazodicarboxylate; GyrA, DNA gyrase A; GyrB, DNA gyrase B; HepG2, human hepatocellular carcinoma; HPLC, high pressure liquid chromatography; HUVEC, human umbilical vein endothelial cells; MIC, minimum inhibitory concentration; MRSA, methicillin-resistant Staphylococcus aureus; MTS, 3-(4,5dimethylthiazol-2-yl)-5-(3-carboxymethoxyphenyl)-2-(4-sulfophenyl)-2H-tetrazolium; NMM, $\mathrm{N}$ methylmorpholine; PA N, phenylalanine-arginine -naphthylamide; ParC, topoisomerase IV subunit A; ParE, topoisomerase IV subunit B; PC, principal component; RA, residual activity; TBTU, $\quad N, N, N c ̧ N c ̧$ tetramethyl-O-(benzotriazol-1-yl)uroniumtetrafluoroborate; $\quad$ THF, tetrahydrofuran; topo IV, topoisomerase IV; VISA, vancomycin-intermediate Staphylococcus aureus.

\section{INTRODUCTION}

Antibiotic-resistant infections kill an estimated 700,000 people each year [1]. Recently, the World Health Organization (WHO) has issued a list of drug-resistant bacteria that pose the greatest threat to human health and thus present a big challenge for antibacterial drug development. Between 2010 and 2015, the US Food and Drug Administration (FDA) approved only eight new antibacterials, and seven of them showed similar mechanism of action to the previously approved antibiotics [2]. Thus, new antibacterial agents with novel mechanisms of action are needed.

Bacterial topoisomerases, DNA gyrase and topoisomerase IV (topo IV), are enzymes that catalyse changes in DNA topology [3]. There are two types of topoisomerases: type I that catalyse single- 
strand breaks, and type II that are responsible for the transient break of two strands of DNA [4]. DNA gyrase and topoisomerase IV belong to type II topoisomerases and display high structural and functional similarities. They are both heterotetrameric enzymes composed of two pairs of subunits. DNA gyrase is composed of two GyrA and two GyrB subunits, while topoisomerase IV is composed of two ParC and two ParE subunits. GyrA and GyrB subunits of DNA gyrase are similar in amino acid sequence to ParC and ParE subunits of topoisomerase IV, respectively [5]. The main function of GyrA/ParC is cleavage and reunion of the DNA molecule, whereas GyrB/ParE binds ATP, providing through its hydrolysis, the energy for the ligation process. DNA gyrase introduces negative supercoils in DNA during replication, whereas topoisomerase IV is involved in the decatenation of the two daughter chromosomes after replication [6].

Being absent in eukaryotes and at the same time an essential enzyme for bacterial survival, DNA gyrase has become an attractive target for the development of antibacterials. Drugs targeting DNA gyrase exert their antibacterial activity via two main mechanisms. The first is stabilisation of the covalent enzyme-DNA complex, i.e. gyrase poisoning. This mechanism is typical of the quinolone class of antibacterials, with ciprofloxacin as the most distinctive representative. The second mechanism involves blocking the ATP binding site of DNA gyrase B. The aminocoumarin natural products novobiocin and clorobiocin are examples of catalytic inhibitors that target the ATP binding site on the GyrB/ParE subunit [4].

Fluoroquinolones have been used extensively in the clinic, resulting in the development of many fluoroquinolone-resistant bacterial strains [7]. The growing resistance problem together with some serious side effects has stimulated the search for new inhibitors which target ATP binding site on DNA gyrase and topoisomerase IV. The only ATPase inhibitor that has been used in the clinic is novobiocin, which was indroduced in the 1960s but was later withdrawn from the market due to its toxicity and weak potency [6,8]. More recently, many structurally diverse classes of GyrB inhibitors have been discovered, such as pyrrolamides [9], benzothiazoles [10], ethyl ureas [11], $N$-phenylpyrrolamides [12-15] and pyrimidoindoles [16] (Figure 1), which possess potent on-target and antibacterial activities but have some liabilities, such as unfavourable physicochemical properties or toxicity issues. 

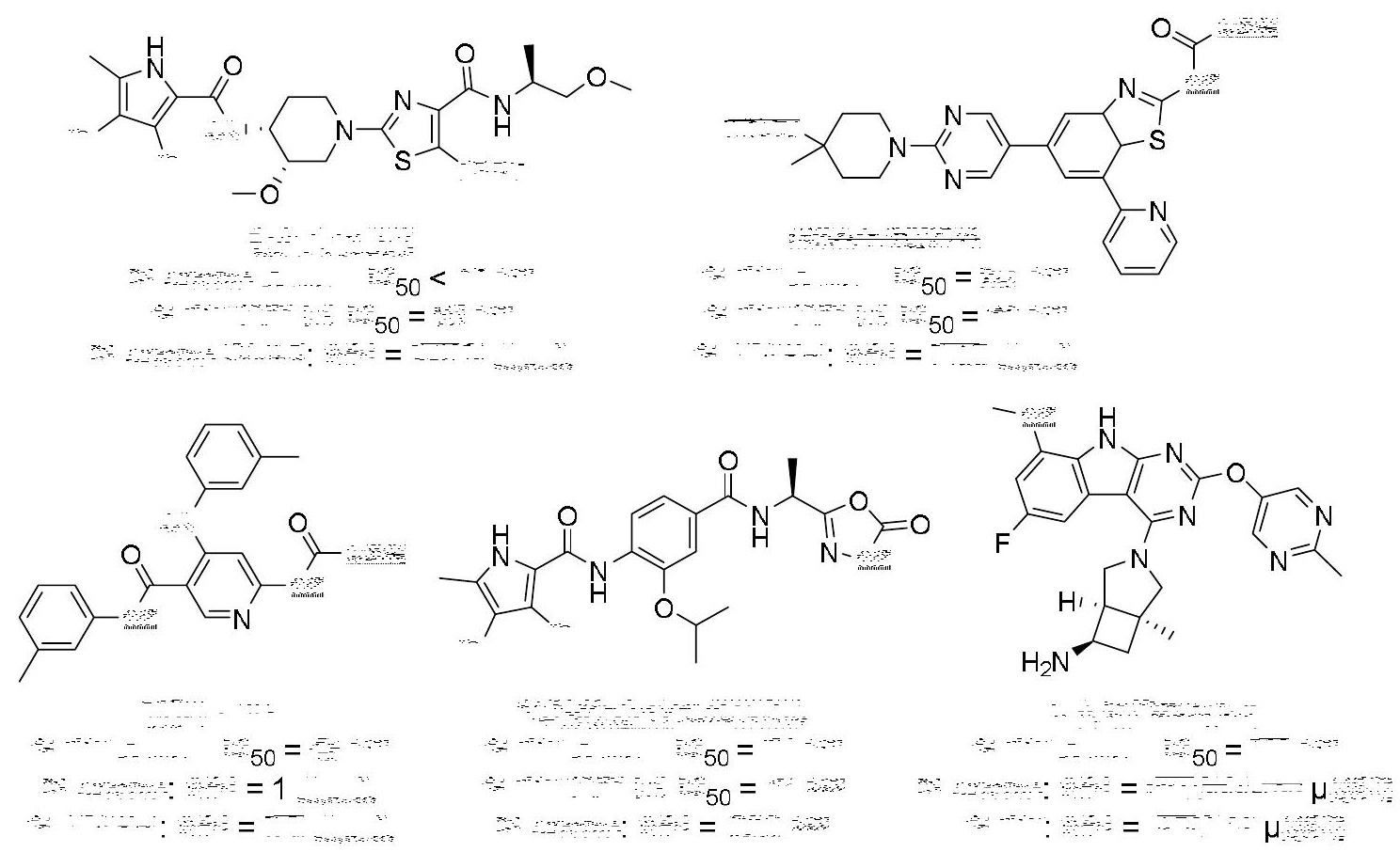

Figure 1. Representative ATP competitive DNA gyrase and topoisomerase IV inhibitors, and their $\mathrm{IC}_{50}$ and MIC values.

\section{RESULTS AND DISCUSSION}

Design. Using our previous $N$-phenylpyrrolamide inhibitors as starting points [12-15], and having at disposal the crystal structure of $E$. coli GyrB in complex with one of our inhibitors (PDB code: 4ZVI) [12], optimised $N$-phenylpyrrolamides were prepared with improved on-target and antibacterial activities. The three structural types of compounds (types I-III, Figure 2) possess modifications on the central part and right-hand sides of the molecules. In all three types of compounds, a hydrogen bond donor-acceptor structural feature was maintained on the left-hand side of the molecules. This part of the inhibitors is fundamental for establishing hydrogen bonding with Asp73 (E. coli numbering) and a structurally conserved water molecule (Figure 2). Additionally, the substituted pyrrole moiety makes important hydrophobic contacts with the hydrophobic pocket composed of Val71, Val43, Val167, and Ala47, which is also the binding site for the clorobiocin 5-methylpyrrole moiety [6]. Two differently substituted pyrrole-2-carboxylic acids were used for preparing the inhibitors: 4,5-dibromopyrrole-2-carboxylic acid and 3,4dichloro-5-methylpyrrole-2-carboxylic acid. The latter was selected preferentially because the 
chlorine atoms are slightly smaller than the bromine atoms and thus fit better into the adenine binding pocket not only of $E$. coli DNA gyrase, but also into the slightly smaller binding pockets of S. aureus DNA gyrase and topoisomerase IV [17].

On the right-hand side of the molecules we introduced acidic groups (e.g. carboxylic acidcontaining groups, such as glycine and $(S)$ - or $(R)$-alanine) capable of forming interactions with the positively charged Arg136 residue, or moieties (e.g. 1,3,4-oxadiazol-2-thione and 5-oxotetrazole) capable of forming cation-å interactions with the Glu50-Arg76 salt bridge and hydrogen bonds with Arg136 side chain. The 1,3,4-oxadiazol-2-thione and 5-oxotetrazole rings were introduced as bioisosteres of carboxylic acid group. The lower acidity of these moieties compared to carboxylic acid was expected to improve entry into bacteria and, consequently, result in better antibacterial activity [18].

Type I compounds contain an alkoxy substituent at the ortho position to the substituted amino group of the central benzene ring (substituent X, Figure 1). The size of this substituent was varied from the bulkier piperidin-4-yloxy, through pyrrolidin-3-yloxy to the smaller isopropoxy group. An amino group-containing heterocycle was selected as substituent $\mathrm{X}$ for three reasons: $i$ ) the possibility of forming hydrophobic contacts with the lipophilic floor of the enzyme (amino acid residues Ile94, Ile78) [14], ii) the possibility of forming additional hydrogen bonds through the ring NH group, and iii) the presence of a positive charge that has recently been associated with an increased level of accumulation in E. coli [19]. It was previously shown by docking studies that the nitrogen atom could form an H-bond with amino acid residue Ala100 that is a part of the flexible loop between amino acid residues Gly97-Ser108 [15]. Moreover, because of the ionic character of the amino group, the water solubility of these compounds is likely to improve. In the case of isopropoxy substituent, only the interactions with the lipophilic floor are possible, but the possibility of establishing H-bond with Ala100 is lost.

Type II compounds, unlike type I, do not contain substituents at the ortho position to the amino group of the central benzene ring. The focus in this series was given on the right part of the molecules, to which chemically diverse groups were introduced, such as sulphonamides, acyl sulfonamides, aliphatic nitriles, malonates or a 5-oxotetrazole ring (Figure 2). Sulfonamides, acyl sulphonamides and 5-oxotetrazole are well-known examples of carboxylic acid isosteres, and have been of fundamental importance in the discovery of novel therapeutics [20] [21]. Nitriles are attractive moieties in medicinal chemistry because of their strong dipole moment and small size, 
that facilitate polar interactions in which the nitrile group acts as a hydroxyl or carboxyl group isostere [22]. Malonic ester derivatives were designed in order to investigate how two carboxylate groups affect the interaction with the Arg136 residue.

In type III compounds, the central phenyl ring was replaced by a bicyclic scaffold to afford a quinolone-like structure or a substituted indole group (Figure 2). To this heterocycle, a carboxylic group was attached to establish ionic bonds with Arg136. With the quinolone derivative, our goal was to prepare a molecular hybrid in which the left-hand side of the molecule is represented by the $N$-phenylpyrrolamide DNA gyrase B-binding motif, and the right-hand side is represented by the 4-oxo-quinoline-2-carboxlic acid moiety, a known DNA gyrase A binder (Figure 3). Targeting both active sites with the same molecule could result in synergistic activity and in a reduced probability of development of bacterial resistance [6].

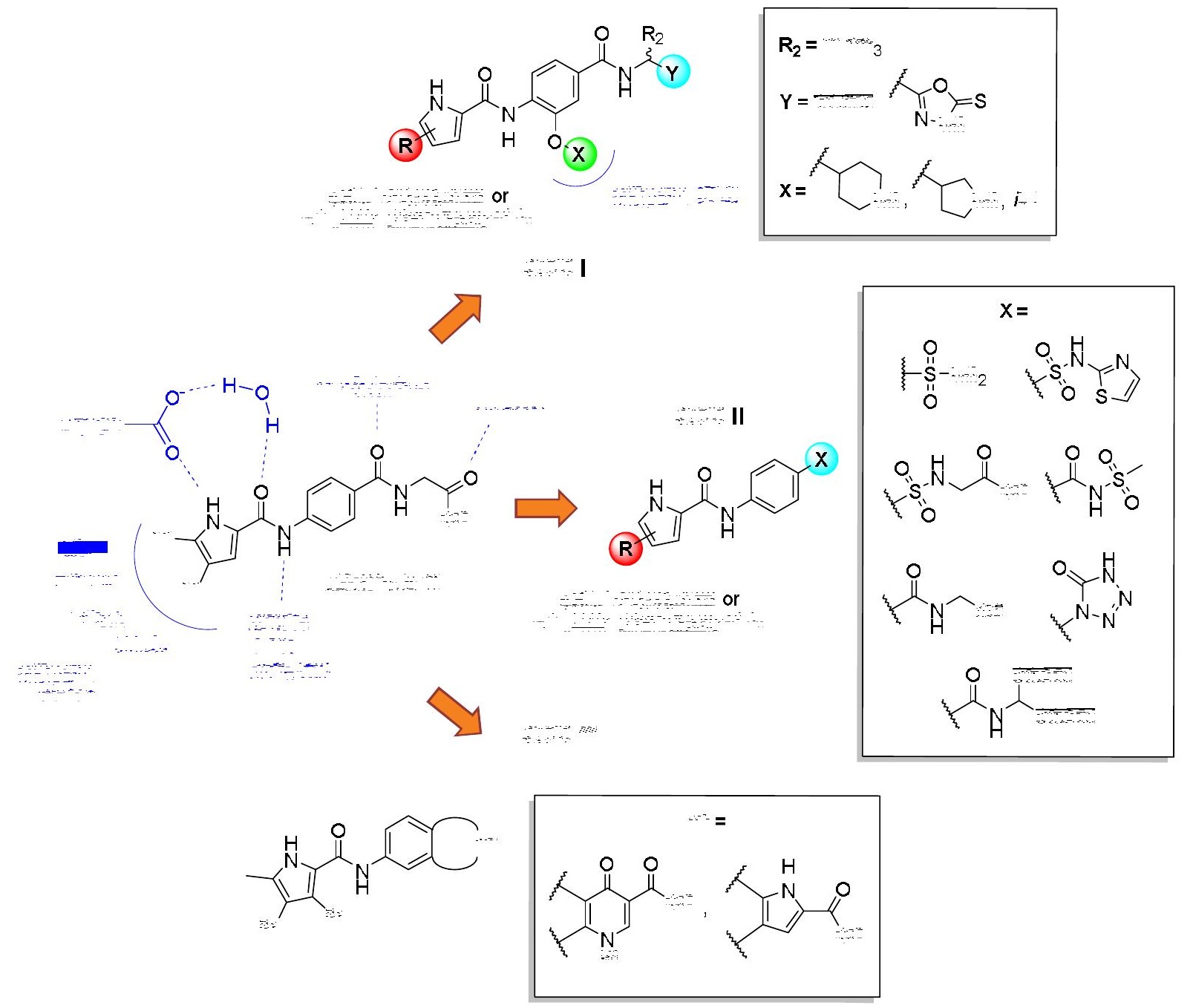


Figure 2. Design of three structural types (I-III) of $N$-phenylpyrrolamides as DNA gyrase B inhibitors, based on the co-crystal structure of the inhibitor A - GyrB (E. coli) (PDB code: 4ZVI [12]).

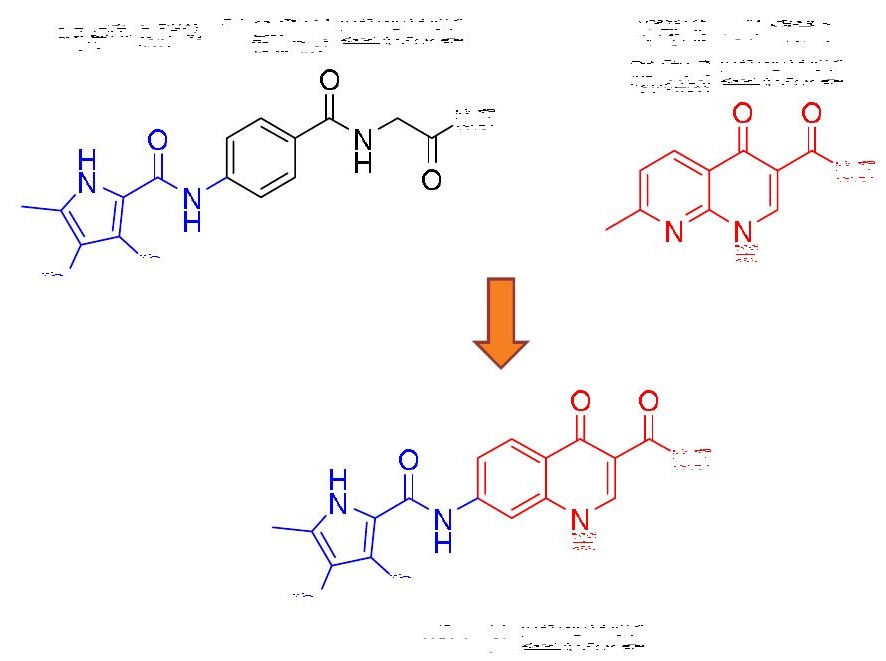

Figure 3. Design of a molecular hybrid inhibitor by merging the left side portion of $\mathrm{N}$ phenylpyrrolamide as a GyrB binder and nalidixic acid as a GyrA binder.

Chemistry. The synthesis of type I compounds (8a-d, 9a-d and 10a-b) is presented in Scheme 1. In the first step, 3-hydroxy-4-nitrobenzoic acid (1) was reacted with thionyl chloride and methanol to afford the corresponding methyl ester $\mathbf{2}$. The hydroxyl group of $\mathbf{2}$ was alkylated with $\mathrm{N}$-Boc-4-hydroxypiperidine under Mitsunobu conditions to afford the intermediate 3. The alkaline hydrolysis of ester $\mathbf{3}$ gave the carboxylic acid $\mathbf{4}$ that was coupled with glycine methyl ester, or $(S)$ or $(R)$-alanine methyl ester using $\quad N, N, N^{\prime}, N^{\prime}$-tetramethyl- $O$-(benzotriazol-1yl)uroniumtetrafluoroborate (TBTU) promoted coupling to yield compounds 5a-c. After catalytic hydrogenation, the resulting anilines 6a-c were coupled with 4,5-dibromopyrrole-2-carboxylic acid or 3,4-dichloro-5-methylpyrrole-2-carboxylic acid. The obtained esters 7a-d underwent alkaline hydrolysis to afford the $\mathrm{N}$-Boc protected compounds 8a-d that were, in turn, reacted with $1 \mathrm{M} \mathrm{HCl}$ in acetic acid or with $4 \mathrm{M} \mathrm{HCl}$ in 1,4-dioxane to give the target compounds 9a-d. Additionally, esters 7c-d underwent the removal of Boc protecting group yielding the products 10a-b. 

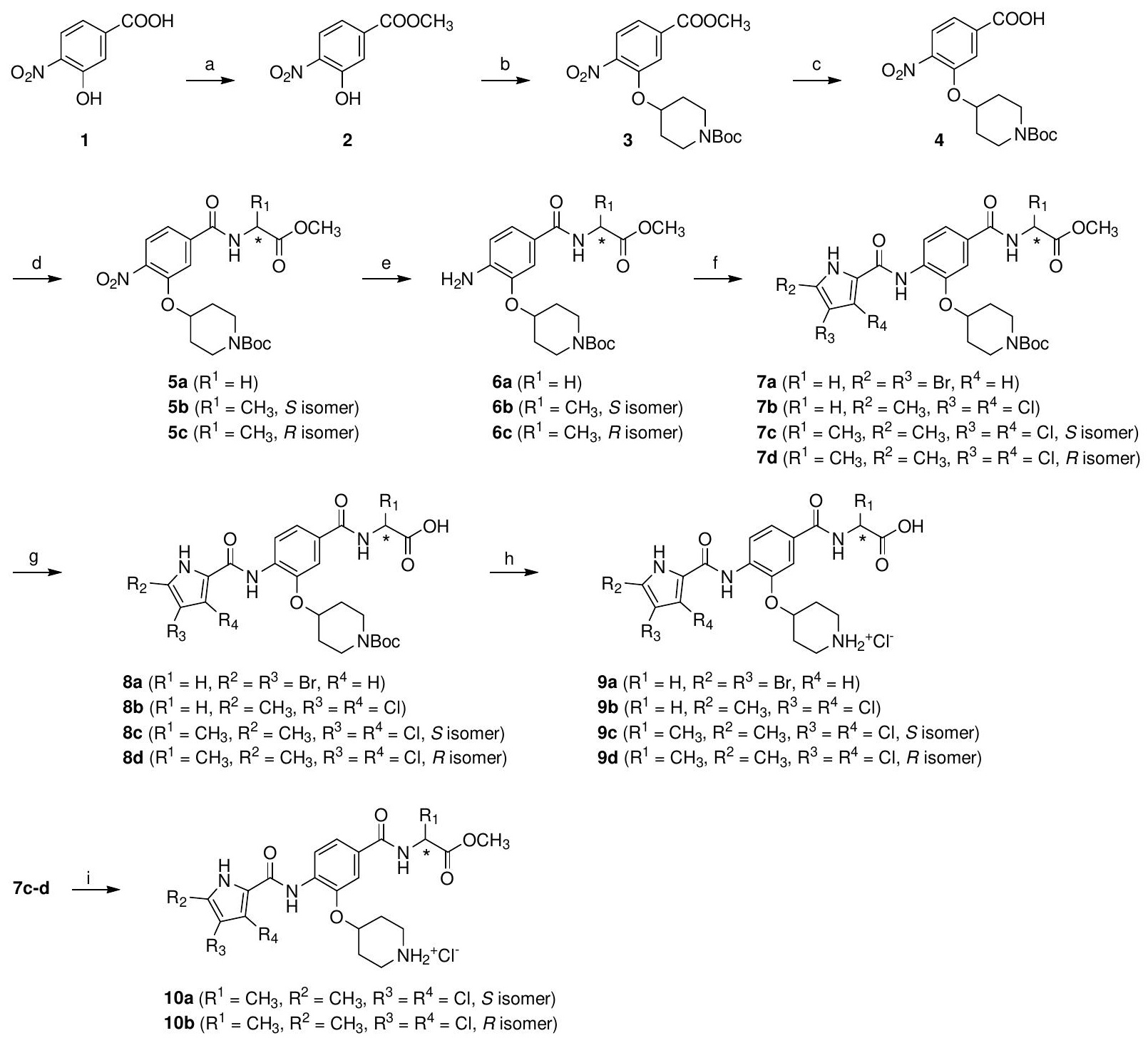

Scheme 1. Reagents and conditions: (a) thionyl chloride, $\mathrm{MeOH}, 0{ }^{\circ} \mathrm{C} \ddagger \mathrm{rt}, 15 \mathrm{~h}$; (b) $\mathrm{PPh}_{3}, \mathrm{DIAD}$, $N$-Boc-4-hydroxypiperidine, anhydrous THF, rt, 15 h; (c) $1 \mathrm{M} \mathrm{NaOH}, \mathrm{MeOH}$, rt, 15 h; (d) glycine methyl ester hydrochloride (for the synthesis of 5a) or $(S)$ - or $(R)$-alanine methyl ester hydrochloride (for the synthesis of 5b-c), TBTU, NMM, anhydrous DMF, $60{ }^{\circ} \mathrm{C}, 12 \mathrm{~h}$; (e) $\mathrm{H}_{2}$, Pd-C, MeOH, rt, 5 h; (f) i) 4,5-dibromopyrrole-2-carboxylic acid or 3,4-dichloro-5methylpyrrole-2-carboxylic acid, oxalyl chloride, anhydrous $\mathrm{CH}_{2} \mathrm{Cl}_{2}, \mathrm{rt}, 15 \mathrm{~h}$, then ii) 6a-c, anhydrous pyridine, anhydrous $\mathrm{CH}_{2} \mathrm{Cl}_{2}, \mathrm{rt}, 15 \mathrm{~h}$; (g) $1 \mathrm{M} \mathrm{NaOH}, \mathrm{MeOH} / \mathrm{THF}, \mathrm{rt}, 15 \mathrm{~h}$ (for the synthesis of 8a-b) or $1 \mathrm{M} \mathrm{LiOH}, \mathrm{MeOH} / \mathrm{THF}, \mathrm{rt}, 15 \mathrm{~h}$ (for the synthesis of 8c-d); (h) $1 \mathrm{M} \mathrm{HCl}$ in acetic acid, DMF, rt, $8 \mathrm{~h}$ (for the synthesis of 9a-b) or $4 \mathrm{M} \mathrm{HCl}$ in 1,4-dioxane, $\mathrm{rt}, 4 \mathrm{~h}$ (for the synthesis of 9c-d); (i) $4 \mathrm{M} \mathrm{HCl}$ in 1,4-dioxane, rt, $4 \mathrm{~h}$. 
The synthesis of compounds 16, 17 and 18, containing a pyrrolidine moiety, is shown in Scheme 2. The pathway is similar to the one described for the preparation of compounds 8a-d, 9a-d and 10a-b (Scheme 1), except that instead of $N$-Boc-4-hydroxypiperidine, $(R)-N$-Boc-3-pyrrolidinol was used as the alcohol moiety for the Mitsunobu reaction in the synthesis of compound $\mathbf{1 1}$.
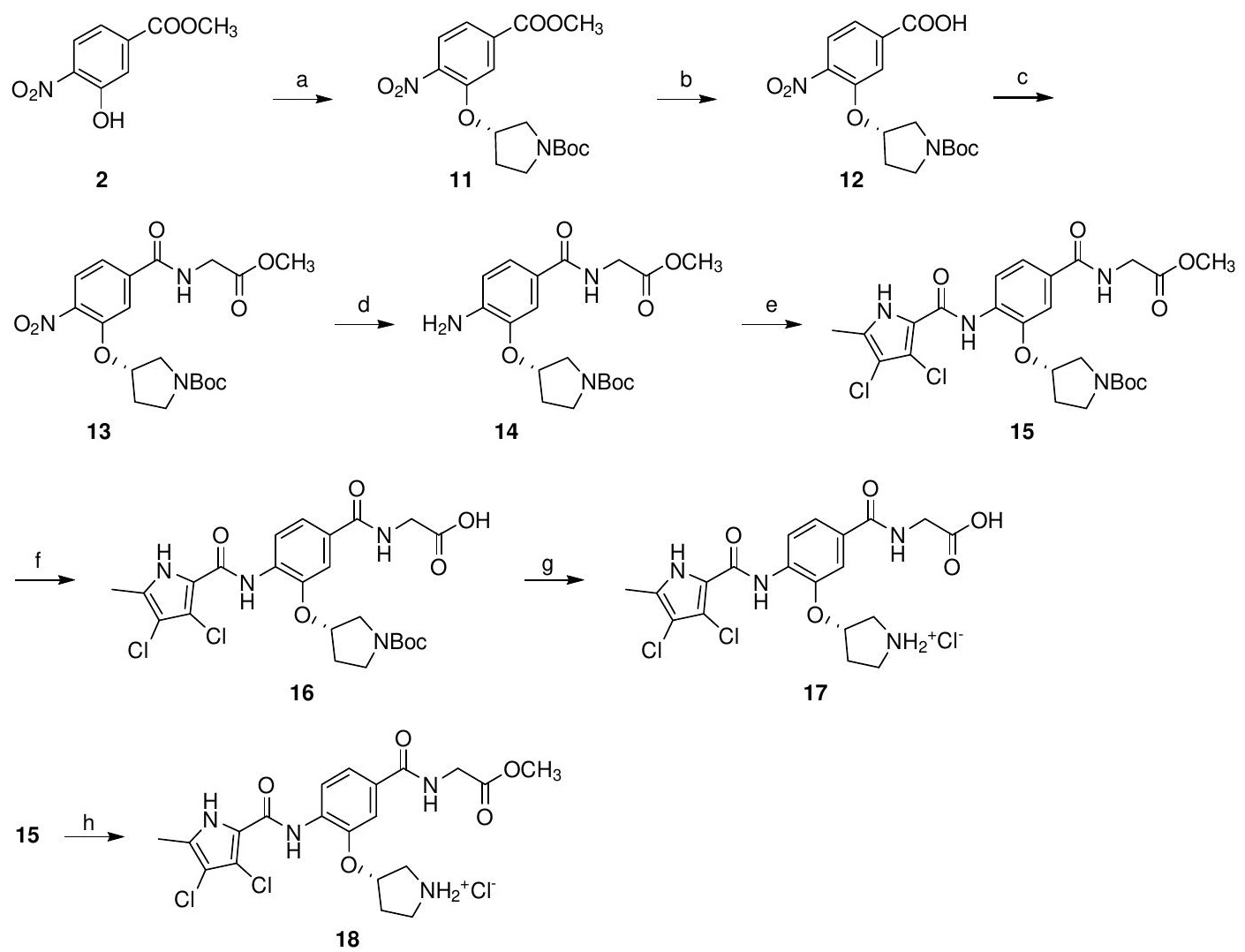

Scheme 2. Reagents and conditions: (a) $\mathrm{PPh}_{3}$, DIAD, $(R)-N$-Boc-3-pyrrolidinol, anhydrous THF, rt, 15 h; (b) $1 \mathrm{M} \mathrm{NaOH}, \mathrm{MeOH}, \mathrm{rt}, 15$ h; (c) glycine methyl ester hydrochloride, TBTU, NMM, anhydrous DMF, $60{ }^{\circ} \mathrm{C}, 12 \mathrm{~h}$; (d) $\mathrm{H}_{2}$, Pd-C, MeOH, rt, 5 h; (e) i) 3,4-dichloro-5-methylpyrrole-2carboxylic acid, oxalyl chloride, anhydrous $\mathrm{CH}_{2} \mathrm{Cl}_{2}, \mathrm{rt}, 15 \mathrm{~h}$, then ii) 14, anhydrous pyridine, anhydrous $\mathrm{CH}_{2} \mathrm{Cl}_{2}$, rt, 15 h; (f) $1 \mathrm{M} \mathrm{NaOH}, \mathrm{MeOH} / \mathrm{THF}$, rt, $15 \mathrm{~h}$ (g) $1 \mathrm{M} \mathrm{HCl}$ in acetic acid, DMF, $\mathrm{rt}, 8 \mathrm{~h}$; (h) $4 \mathrm{M} \mathrm{HCl}$ in 1,4-dioxane, rt, $4 \mathrm{~h}$.

The synthesis of compound 25 is shown in Scheme 3. The isopropoxy derivative 19, obtained under Mitsunobu conditions from compound 2, underwent alkaline hydrolysis to afford the acid 20. The 
coupling of $\mathbf{2 0}$ with $(R)$-alanine methyl ester hydrochloride, followed by catalytic hydrogenation, gave the aniline 22 which was reacted with 3,4-dichloro-5-methylpyrrole-2-carbonyl chloride to afford the ester $\mathbf{2 3}$. The hydrazinolysis of $\mathbf{2 3}$ yielded $\mathbf{2 4}$ which was reacted with 1,1ç thiocarbonyldiimidazole to give the final product 25.
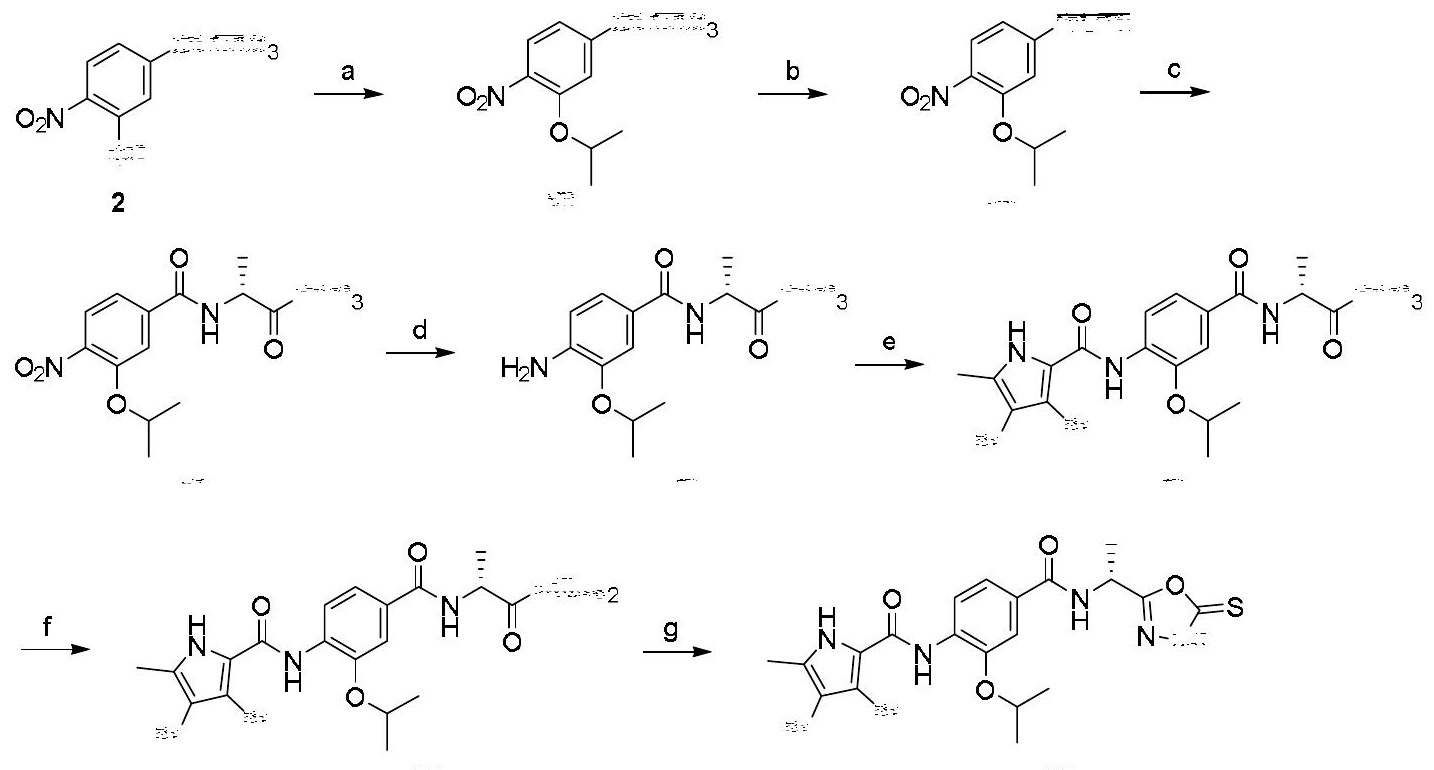

Scheme 3. Reagents and conditions: (a) $\mathrm{PPh}_{3}$, DIAD, isopropanol, anhydrous THF, rt, $15 \mathrm{~h}$; (b) 1 $\mathrm{M} \mathrm{NaOH}, \mathrm{MeOH}, \mathrm{rt}, 15$ h; (c) (R)-alanine methyl ester hydrochloride, TBTU, NMM, anhydrous DMF, $60{ }^{\circ} \mathrm{C}, 12 \mathrm{~h}$; (d) $\mathrm{H}_{2}$, Pd-C, MeOH, rt, 5 h; (e) i) 3,4-dichloro-5-methylpyrrole-2-carboxylic acid, oxalyl chloride, anhydrous $\mathrm{CH}_{2} \mathrm{Cl}_{2}, \mathrm{rt}, 15 \mathrm{~h}$, then ii) 22, anhydrous pyridine, anhydrous $\mathrm{CH}_{2} \mathrm{Cl}_{2}$, rt, $15 \mathrm{~h}$; (f) hydrazine hydrate, dry MeOH/dry THF, reflux, $15 \mathrm{~h}$; (g) 1,1€ thiocarbonyldiimidazole, 1,4-dioxane/DMF, $100{ }^{\circ} \mathrm{C}, 15 \mathrm{~h}$.

The synthesis of type II compounds 27, 29, 34 and 39 is presented in Scheme 4. Compounds 27 and 29 were obtained by coupling 3,4-dichloro-5-methyl-1H-pyrrole-2-carbonyl chloride, with sulfanilamide (26) and sulfathiazole (28), respectively. For the preparation of compound 34, 4nitrobenzenesulfonyl chloride (30) was mixed with glycine methyl ester hydrochloride in the presence of triethylamine to give 31, which underwent catalytic reduction to yield $\mathbf{3 2}$. The final product $\mathbf{3 4}$ was obtained after alkaline hydrolysis of the ester 33, obtained by coupling of $\mathbf{3 2}$ and 3,4-dichloro-5-methyl-1H-pyrrole-2-carbonyl chloride. 
For the synthesis of compound 39, methanesulfonyl chloride (35) was reacted with gaseous ammonia to obtain methanesulfonamide (36). Compound 36 was then mixed with 4-nitrobenzoyl chloride in the presence of triethylamine to obtain 37 which, after catalytic hydrogenation, generated compound 38 that was coupled with 3,4-dichloro-5-methyl-1H-pyrrole-2-carbonyl chloride to yield the acyl sulfonamide 39.
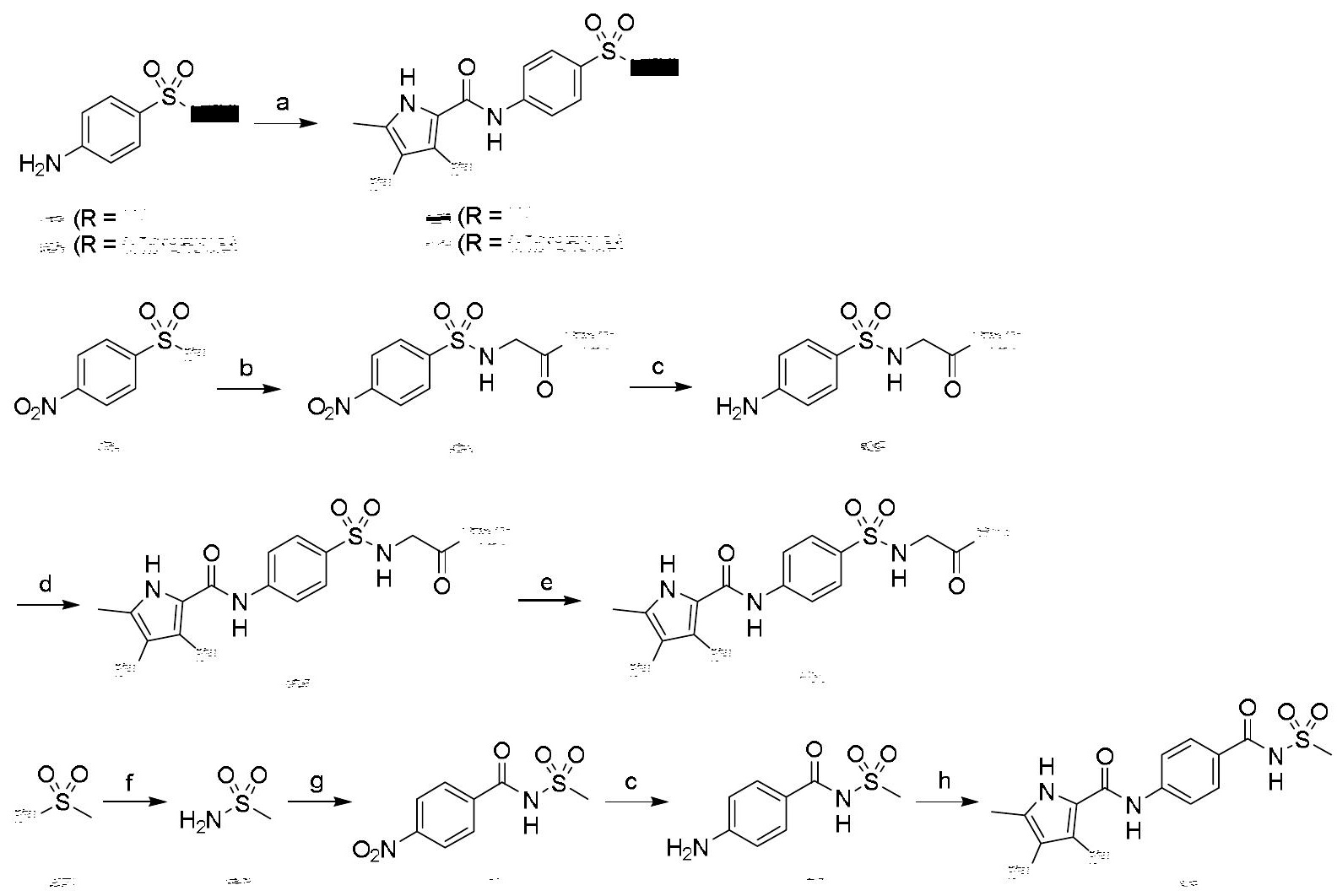

Scheme 4. Reagents and conditions: (a) i) 3,4-dichloro-5-methylpyrrole-2-carboxylic acid, oxalyl chloride, anhydrous $\mathrm{CH}_{2} \mathrm{Cl}_{2}$, rt, $15 \mathrm{~h}$, then ii) 26, anhydrous pyridine, anhydrous THF, rt, $15 \mathrm{~h}$ for the synthesis of $\mathbf{2 7}$ or ii) $\mathbf{2 8}$, anhydrous pyridine, anhydrous THF, rt, 15 h for the synthesis of $\mathbf{2 9}$; (b) glycine methyl ester hydrochloride, triethylamine, $\mathrm{CH}_{2} \mathrm{Cl}_{2}, 0{ }^{\circ} \mathrm{C} \ddagger \mathrm{rt}, 12 \mathrm{~h}$; (c) $\mathrm{H}_{2}, \mathrm{Pd}-\mathrm{C}$, $\mathrm{MeOH}, \mathrm{rt}, 3 \mathrm{~h}$; (d) i) 3,4-dichloro-5-methylpyrrole-2-carboxylic acid, oxalyl chloride, anhydrous $\mathrm{CH}_{2} \mathrm{Cl}_{2}$, rt, $15 \mathrm{~h}$, then ii) 32, anhydrous pyridine, anhydrous $\mathrm{THF}, \mathrm{rt}, 15 \mathrm{~h}$; (e) $1 \mathrm{M} \mathrm{NaOH}$, $\mathrm{MeOH} / \mathrm{THF}, \mathrm{rt}, 15 \mathrm{~h}$; (f) gaseous ammonia, anhydrous THF, $0{ }^{\circ} \mathrm{C}, 0.5 \mathrm{~h}$; (g) 4-nitrobenzoyl chloride, triethylamine, anhydrous $\mathrm{CH}_{2} \mathrm{Cl}_{2}, 0{ }^{\circ} \mathrm{C} \ddagger \mathrm{rt}, 12 \mathrm{~h}$; (h) i) 3,4-dichloro-5-methylpyrrole-2carboxylic acid, oxalyl chloride, anhydrous $\mathrm{CH}_{2} \mathrm{Cl}_{2}, \mathrm{rt}, 15 \mathrm{~h}$, then $\mathrm{ii}$ ) 38, anhydrous pyridine, anhydrous THF, rt, $15 \mathrm{~h}$. 
The synthesis of compounds 43a-b, 46a-b and $\mathbf{5 0}$ is shown in Scheme 5. For the preparation of the aliphatic nitriles 43a-b, aminoacetonitrile hydrochloride was firstly coupled with 4-nitro benzoic acid (40) using TBTU methodology. The nitro group of the obtained intermediate $\mathbf{4 1}$ was then reduced to give compound $\mathbf{4 2}$ which was reacted with 4,5-dibromo- $1 H$-pyrrole-2-carbonyl chloride or 3,4-dichloro-5-methyl-1H-pyrrole-2-carbonyl chloride to afford the final products $\mathbf{4 3 a - b}$. The malonates $\mathbf{4 6 a - b}$ were prepared by reacting 40 with diethyl aminomalonate hydrochloride via TBTU methodology. Compound $\mathbf{4 4}$ underwent catalytic hydrogenation to give the substituted aniline 45 which was reacted with 4,5-dibromo-1H-pyrrole-2-carbonyl chloride or 3,4-dichloro-5methyl-1H-pyrrole-2-carbonyl chloride to afford the final compounds $\mathbf{4 6 a}$ or $\mathbf{4 6} \mathbf{b}$. The hydrolysis of ethyl ester groups of 46a-b was unsuccessful as decarboxylation was observed. The 5oxotetrazole derivative $\mathbf{5 0}$ was prepared by mixing 4-nitrobenzoyl chloride (47) with azidotrimethylsilane to give compound $\mathbf{4 8}$ via initial acylazide formation and subsequent Curtius rearrangement [23]. The following catalytic hydrogenation of $\mathbf{4 8}$ and the coupling of the amine 49 with 3,4-dichloro-5-methyl-1 $H$-pyrrole-2-carbonyl chloride yielded the final compound $\mathbf{5 0}$.
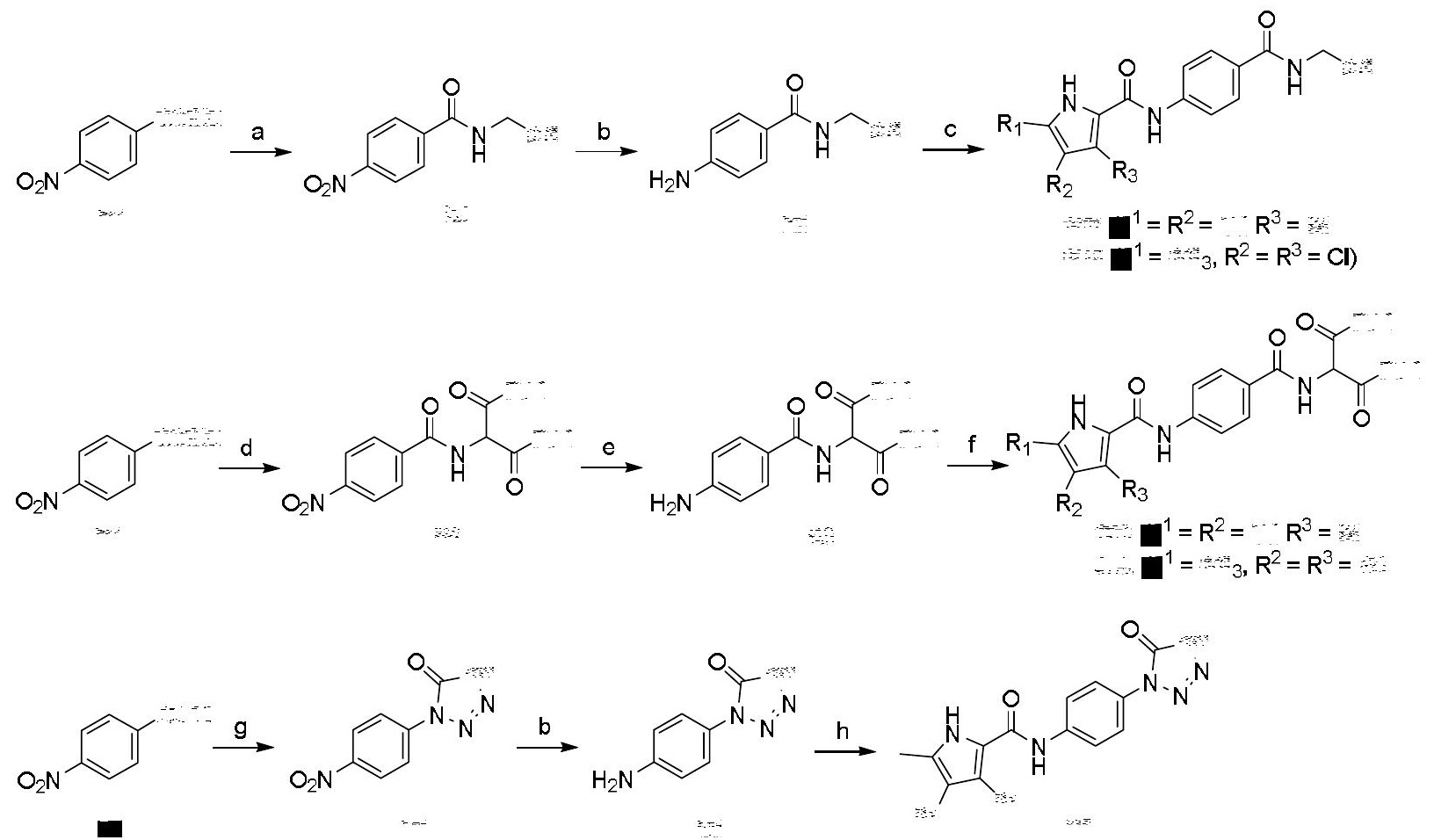
Scheme 5. Reagents and conditions: (a) aminoacetonitrile hydrochloride, TBTU, NMM, anhydrous DMF, $60{ }^{\circ} \mathrm{C}, 12 \mathrm{~h}$; (b) $\mathrm{H}_{2}$, Pd-C, MeOH, rt, 3 h; (c) i) 4,5-dibromopyrrole-2-carboxylic acid or 3,4-dichloro-5-methylpyrrole-2-carboxylic acid, oxalyl chloride, anhydrous $\mathrm{CH}_{2} \mathrm{Cl}_{2}, \mathrm{rt}, 15$ h, then ii) 42, anhydrous pyridine, anhydrous $\mathrm{CH}_{2} \mathrm{Cl}_{2}$, rt, $15 \mathrm{~h}$ (for the synthesis of 43a-b); (d) diethyl aminomalonate hydrochloride, TBTU, NMM, anhydrous DMF, $60{ }^{\circ} \mathrm{C}, 12 \mathrm{~h}$; (e) $\mathrm{H}_{2}, \mathrm{Pd}-\mathrm{C}$, EtOH, rt, 3 h; (f) i) 4,5-dibromopyrrole-2-carboxylic acid or 3,4-dichloro-5-methylpyrrole-2carboxylic acid, oxalyl chloride, anhydrous $\mathrm{CH}_{2} \mathrm{Cl}_{2}, \mathrm{rt}, 15 \mathrm{~h}$, then $\mathrm{ii}$ ) 45, anhydrous pyridine, anhydrous $\mathrm{CH}_{2} \mathrm{Cl}_{2}$, rt, $15 \mathrm{~h}$ (for the synthesis of $\mathbf{4 6 a - b}$ ); (g) azidotrimethylsilane, $90{ }^{\circ} \mathrm{C}$, $12 \mathrm{~h}$; (h) 3,4-dichloro-5-methylpyrrole-2-carboxylic acid, oxalyl chloride, anhydrous $\mathrm{CH}_{2} \mathrm{Cl}_{2}, \mathrm{rt}, 15 \mathrm{~h}$, then ii) 49, anhydrous pyridine, anhydrous $\mathrm{CH}_{2} \mathrm{Cl}_{2}$, rt, $15 \mathrm{~h}$.

The synthesis of type III compounds $\mathbf{5 7}$ and $\mathbf{6 1}$ is presented in Scheme 6. For the synthesis of compound 57 we employed the Gould-Jacobs route [24]. 3-Nitroaniline (51) was first mixed with diethyl ethoxymethylenemalonate to give the derivative 52. This was then cyclized in diphenyl ether as a solvent to afford compound $\mathbf{5 3}$, which was subsequently alkylated with ethyl bromide to form 54. The nitro group of $\mathbf{5 4}$ was reduced with catalytic hydrogenation and the resulting aniline 55 was coupled with 3,4-dichloro-5-methyl-1H-pyrrole-2-carbonyl chloride to give the ester 56. Compound 56 underwent alkaline hydrolysis to yield the final quinolone 57. For the synthesis of the indole derivative 61, compound $\mathbf{5 8}$ was first reduced to the corresponding amine 59, which was then reacted with 3,4-dichloro-5-methyl-1H-pyrrole-2-carbonyl chloride to give the ester 60. Finally, the alkaline hydrolysis of ethyl ester group of $\mathbf{6 0}$ afforded the final product $\mathbf{6 1}$. 


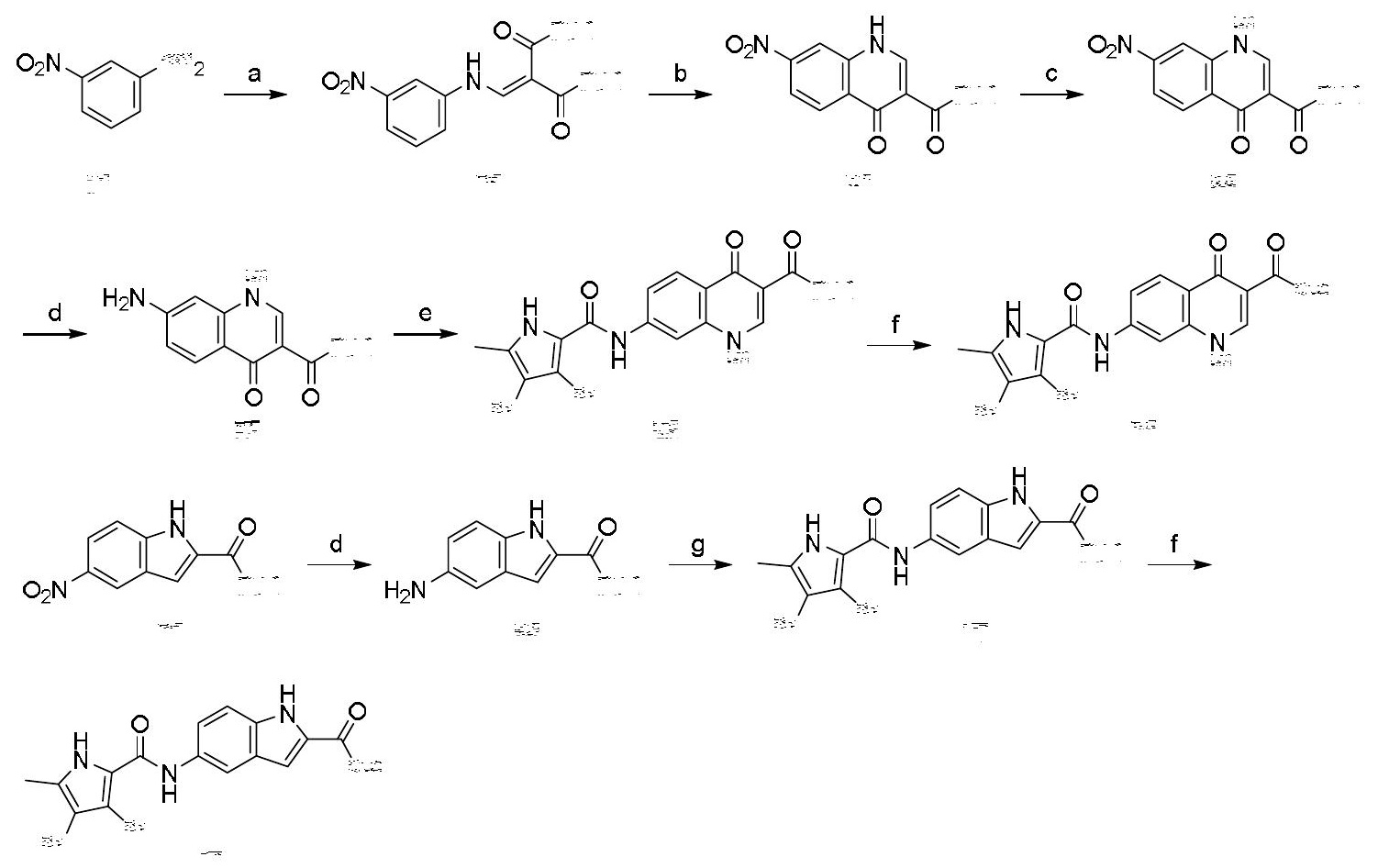

Scheme 6. Reagents and conditions: (a) diethyl ethoxymethylenemalonate, $90^{\circ} \mathrm{C}, 3 \mathrm{~h}$; (b) diphenyl ether, $260^{\circ} \mathrm{C}, 2.5 \mathrm{~h}$; (c) ethyl bromide, $\mathrm{K}_{2} \mathrm{CO}_{3}$, anhydrous DMF, $70{ }^{\circ} \mathrm{C}, 12 \mathrm{~h}$; (d) $\mathrm{H}_{2}, \mathrm{Pd}-\mathrm{C}$, EtOH, rt, 3 h (e) $i$ ) 3,4-dichloro-5-methylpyrrole-2-carboxylic acid, oxalyl chloride, anhydrous $\mathrm{CH}_{2} \mathrm{Cl}_{2}$, rt, $15 \mathrm{~h}$, then ii) 55, anhydrous pyridine, anhydrous $\mathrm{CH}_{2} \mathrm{Cl}_{2}$, rt, $15 \mathrm{~h}$; (f) $1 \mathrm{M} \mathrm{NaOH}, \mathrm{EtOH} / 1,4-$ dioxane, $\mathrm{rt}, 5 \mathrm{~h}$; (g) i) 3,4-dichloro-5-methylpyrrole-2-carboxylic acid, oxalyl chloride, anhydrous $\mathrm{CH}_{2} \mathrm{Cl}_{2}, \mathrm{rt}, 15 \mathrm{~h}$, then ii) 59, anhydrous pyridine, anhydrous $\mathrm{CH}_{2} \mathrm{Cl}_{2}, \mathrm{rt}, 15 \mathrm{~h}$.

Inhibitory Activities Against DNA Gyrase and Topoisomerase IV. Thirty-five new compounds were synthesized and evaluated for their inhibitory activity against E. coli DNA gyrase in a supercoiling assay. The results are presented either as residual activities (RAs) of the enzyme at 1 $\mu \mathrm{M}$ of compounds or as $\mathrm{IC}_{50}$ values (Tables 1-3). The most potent compounds were additionally evaluated against $S$. aureus DNA gyrase, and against $E$. coli and $S$. aureus topoisomerase IV (Table 4). To determine possible binding modes of compounds, molecular docking of all tested compounds to the E. coli GyrB binding site was performed using GOLD software [25] and the results are presented in Supporting information.

Thirteen compounds (8b, 8c, 9a-d, 10a-b, 16, 17, 18, 50 and 61 ) showed potent inhibition of $E$. coli DNA gyrase with low nanomolar inhibitory values $\left(\mathrm{IC}_{50}<100 \mathrm{nM}\right)$. Twelve of these inhibitors 
contained the 3,4-dichloro-5-methyl-1H-pyrrole moiety in the left-hand side of the molecule, which thus proved to be more optimal than 4,5-dibromo- $1 H$-pyrrole group. In general, carboxylic acid derivatives possessed stronger activity than the corresponding methyl ester derivatives. As an example of this trend, the carboxylic acid $\mathbf{8 b}$ exhibited an $\mathrm{IC}_{50}$ value of $86 \mathrm{nM}$ whereas the ester 7b was inactive $(\mathrm{RA}=100 \%)$. The reason for this difference stems from the ability of carboxylic acids (and not of esters) to form salt bridge with Arg136 residue (Figure 1S of Supporting information).

Type I inhibitors with carboxylic groups on the right-hand side of the molecule and amino groupcontaining heterocycles attached at the ortho position to the amino group on benzene ring (substituent X, Figure 1) (9a, 9b, 9c, 9d and 17) proved to be the most potent inhibitors of DNA gyrase within the series ( $\mathrm{IC}_{50} \hat{\imath} 31 \mathrm{nM}$ ). Piperidin-4-yloxy and pyrrolidin-3-yloxy substituents are most probably forming favourable interactions with the hydrophobic floor of the enzyme. Moreover, the amino group of these heterocycles can potentially form a hydrogen bond with Ala100 that is part of the flexible loop between amino acid residues Gly97-Ser108, as predicted by docking of compound 9d $\left(\mathrm{IC}_{50}=6.9 \mathrm{nM}\right)$ to the DNA gyrase $\mathrm{B}$ active site (Figure $\left.1 \mathrm{~S}\right)$, and as reported by our research group for a related compound [15]. Interestingly, also some derivatives containing a combination of $\mathrm{N}$-Boc-protected amino group and free carboxylic acid group on the right-hand side, e.g. compounds $\mathbf{8 b}, \mathbf{8 c}, \mathbf{8 d}$ and 16, showed good activity against E. coli gyrase $\left(\mathrm{IC}_{50} \hat{\imath} 100 \mathrm{nM}\right)$. Also, the positively charged ester derivatives 10a, 10b and 18 showed good activities on the enzyme with $\mathrm{IC}_{50}$ values of $40 \mathrm{nM}, 48 \mathrm{nM}$ and $74 \mathrm{nM}$, respectively. On the other hand, compounds with simultaneous presence of the methyl ester group on the right-hand side and $N$-Boc-protected heterocycle (7c, 7d and 15) were inactive (RA $=83 \%, 94 \%$ and $93 \%$ respectively). The activities of pyrrolidine derivatives were comparable to the activities of their piperidine-containing counterparts, as can be seen by comparing, e.g. pyrrolidine $17\left(\mathrm{IC}_{50}=31\right.$ $\mathrm{nM})$ to piperidine $9 \mathbf{b}\left(\mathrm{IC}_{50}=17 \mathrm{nM}\right)$ and pyrrolidine $\mathbf{1 6}\left(\mathrm{IC}_{50}=92 \mathrm{nM}\right)$ to piperidine $\mathbf{8 b}\left(\mathrm{IC}_{50}=86\right.$ $\mathrm{nM})$. Among the isopropoxy derivatives, compound 25 with a 1,3,4-oxadiazol-2-thione ring attached to the right-hand side, displayed a significantly higher activity $\left(\mathrm{IC}_{50}=190 \mathrm{nM}\right)$ compared to its corresponding hydrazide $24(\mathrm{RA}=89 \%)$ or ester analogue $23(\mathrm{RA}=87 \%)$. Compounds $9 \mathrm{c}$ $\left(\mathrm{IC}_{50}=9.9 \mathrm{nM}\right)$ and $9 \mathrm{~d}\left(\mathrm{IC}_{50}=6.9 \mathrm{nM}\right)$ with $(S)$ - and $(R)$-alanine groups attached to the right-hand side proved to be on the same order of potency as their glycine relative $9 \mathbf{b}\left(\mathrm{IC}_{50}=17 \mathrm{nM}\right)$. There were no marked differences in activities between the $(S)$ - and $(R)$-alanine isomers. 
Overall, type II inhibitors were less potent than type I compounds, which is probably due to the absence of substituents at the ortho position to the amino group on the benzene ring. The focus in type II compounds was to study the effects of different substituents on the right-hand side of the molecule. Three compounds - acyl sulfonamide 39, aliphatic nitrile 43b and 5-oxotetrazole 50 displayed good $\mathrm{IC}_{50}$ values of $160 \mathrm{nM}, 410 \mathrm{nM}$ and $77 \mathrm{nM}$, respectively. Owing to the acidity of its NH group, acyl sulphonamides are commonly used as carboxylic acid isosteres [26]. Moreover, compounds containing this functional group often show improved oral availability, metabolic stability and potency compared to the parent carboxylic acids [27]. The nitrile $\mathbf{4 3 b}$ and its dibromo pyrrole analogue 43a were synthesised because of the important roles that nitrile groups have as hydrogen bond acceptors [28]. The nitrile functionality can act as a carboxylic acid isostere, which has been exploited in the design of vildagliptin [22]. Nitrile-containing quinolones with good potency and safe therapeutic profiles were also reported [29]. Similarly, 5-oxotetrazole derivative $\mathbf{5 0}$ was prepared as a carboxylic acid isostere. The $\mathrm{NH}$ group at the 4-position of 5-oxotetrazole has a similar pKa value to the NH of tetrazole [21]. Given the smaller size of compound 50 compared to type I inhibitors, it is expected that the 5-oxotetrazole ring is making interactions with Arg76 rather than Arg136. Other compounds of the type II series, such as sulfonamides 27, 29, 33 and $34(\mathrm{RA}=82 \%, 100 \%, 87 \%$ and $87 \%$ respectively), and malonic ester derivatives 46a $(\mathrm{RA}=$ $78 \%)$ and $46 \mathrm{~b}\left(\mathrm{IC}_{50}=7700 \mathrm{nM}\right)$, were not active on E. coli DNA gyrase. This can perhaps be explained with the weaker acidity of sulfonamides (pKa range: 7.3-9.7 [30]) compared to carboxylic acids, while the weak inhibitory values of malonic ester derivatives are in line with those of most esters in the type I series and additionally suggest that the malonic functionality could be too bulky to establish strong interactions with Arg136.

The type III compounds contain a quinolone-like structure (56 and 57) or a substituted indole moiety (60 and 61) and are more rigid than the compounds belonging to type I and II series. Among the two quinolones, the ester 56 interestingly showed stronger activity $\left(\mathrm{IC}_{50}=53 \mathrm{nM}\right)$ than the corresponding carboxylic acid analogue $57\left(\mathrm{IC}_{50}=1400 \mathrm{nM}\right)$. The opposite was observed in the indole series, where the carboxylic acid $\mathbf{6 1}$ displayed excellent inhibitory activity $\left(\mathrm{IC}_{50}=98 \mathrm{nM}\right)$ whereas the ethyl ester analogue $\mathbf{6 0}$ was completely inactive $(\mathrm{RA}=100 \%)$.

Some of the prepared compounds displayed promising activities also on DNA gyrase from $S$. aureus and on topoisomerase IV from $E$. coli and $S$. aureus, although the activities were generally 
lower than those on E. coli DNA gyrase (Table 4). Compounds 9c and 9d, that were the most potent on $E$. coli $\mathrm{DNA}$ gyrase $\left(\mathrm{IC}_{50}=9.9 \mathrm{nM}\right.$ and $\mathrm{IC}_{50}=6.9 \mathrm{nM}$, respectively), were also among the most potent inhibitors of these three enzymes. In particular, derivative 9c displayed a nanomolar activity against $S$. aureus DNA gyrase $\left(\mathrm{IC}_{50}=99 \mathrm{nM}\right)$ and a good activity against topoisomerase IV from S. aureus $\left(\mathrm{IC}_{50}=689 \mathrm{nM}\right)$. Compound 9d, the D-enantiomer of 9c, showed slightly weaker activity on the $S$. aureus gyrase, but was comparably active on all other tested enzymes. Similarly as for $E$. coli gyrase, zwitterionic compounds 9b-d and $\mathbf{1 7}$ were the most potent in the series, which underlines the importance of the carboxylic moiety on the right-hand side of the molecules and the amino group-containing heterocycles on the central benzene ring for the binding affinity. Because of the slightly bigger size of bromine atoms compared to chlorine atoms, and because of the smaller size of the ATP binding pocket of $S$. aureus gyrase and of topo IV, the dibromopyrrole derivative 9a was less active against those enzymes. In addition to zwitterionic compounds, also the methyl ester derivatives $\mathbf{1 0 a}, \mathbf{1 0 b}$ and 18 showed moderate activities, with L-alanine derivative 10a being the best. Derivatives containing an alanine group attached to the right-hand side $(\mathbf{8 c}, 8 \mathbf{8 d}, 9 \mathbf{c}, 9 \mathbf{d}$, 10a-b and 25) were generally more potent than their glycine counterparts, but glycine-containing compound 9b displayed the best activity against E. coli topoisomerase IV among all tested compounds, with $\mathrm{IC}_{50}$ value of $7200 \mathrm{nM}$. Compound 25 with an isopropoxy group on the benzene ring, showed much weaker activity than compounds with piperidin-4-yloxy (e.g. 8b-c, 9b-d and 10a) and pyrrolidin-3-yloxy (17 and 18) substituents. Type II and type III inhibitors, did not exhibit promising activities on the $S$. aureus gyrase and on topo IV, which could be explained by the lack of the ortho substituents capable of forming favourable hydrophobic interactions or hydrogen bonds with the enzyme.

Table 1. Inhibitory activities of type I compounds against DNA gyrase from E. coli.

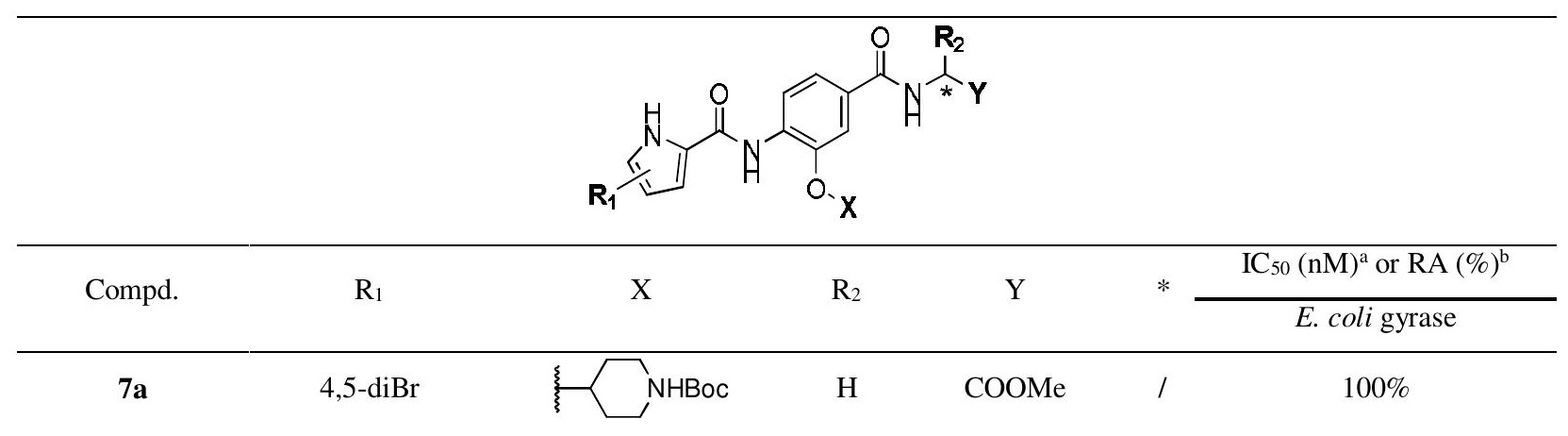




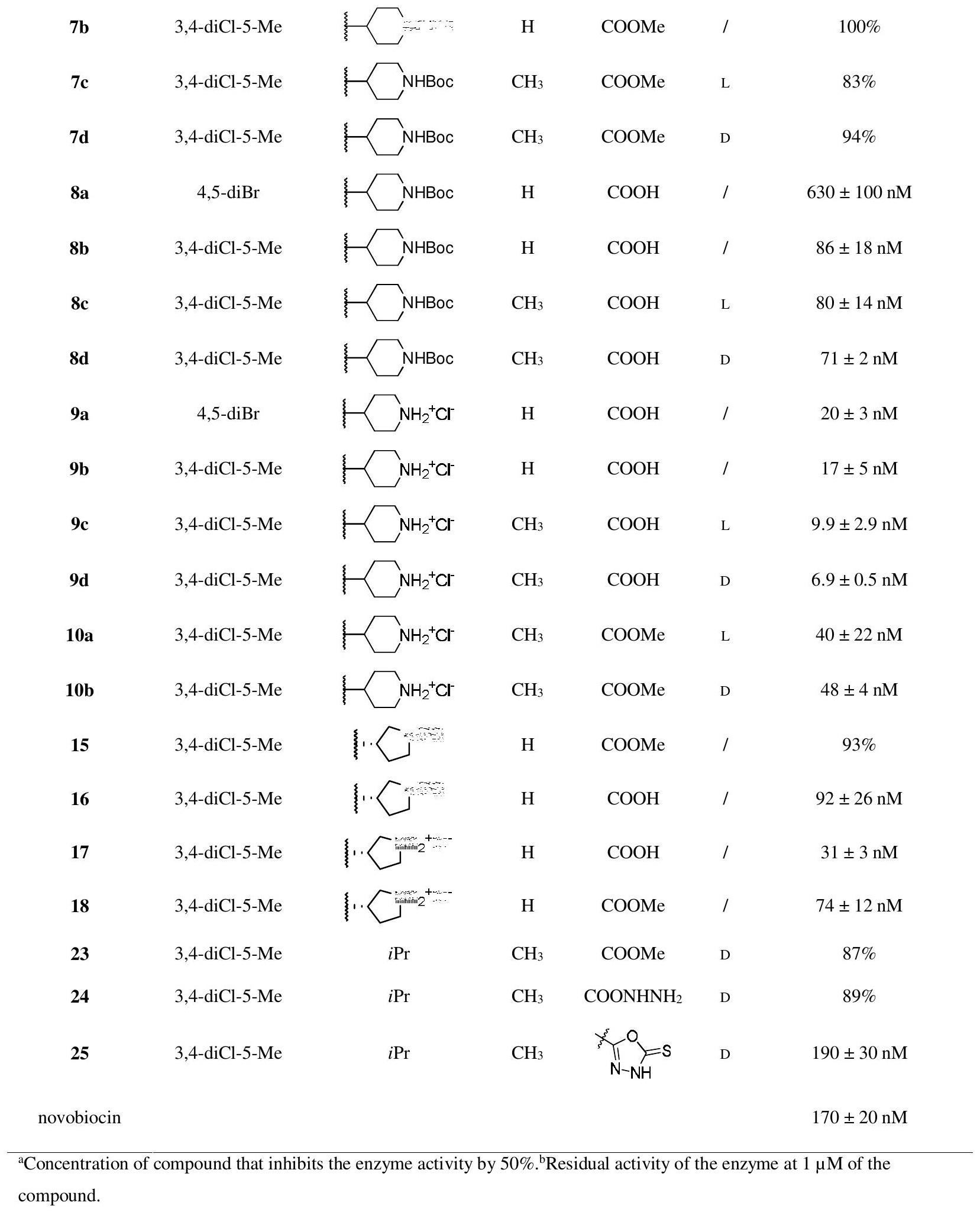

Table 2. Inhibitory activities of type II compounds against DNA gyrase from E. coli. 


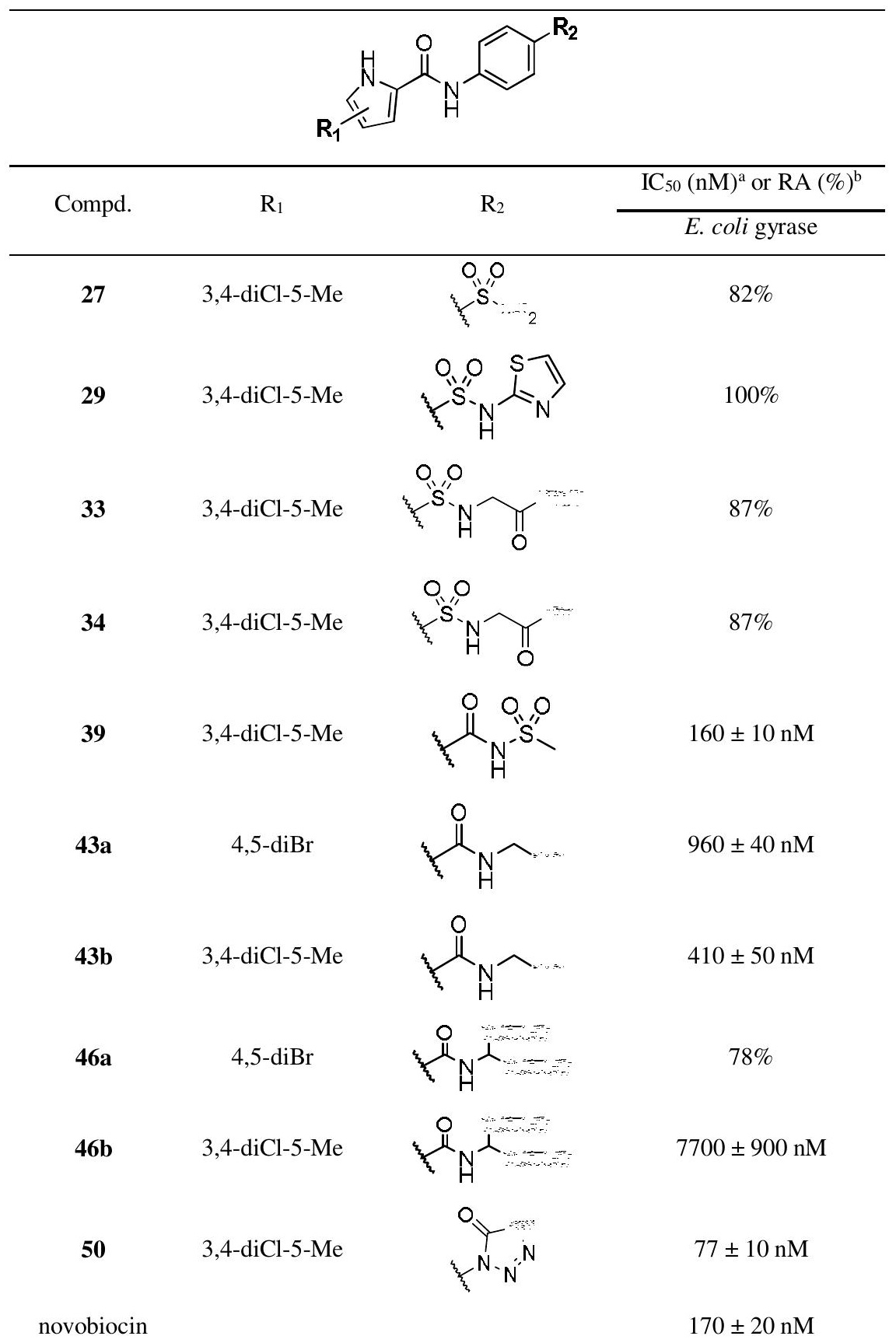

${ }^{a}$ Concentration of compound that inhibits the enzyme activity by $50 \%$. ${ }^{\mathrm{b}}$ Residual activity of the enzyme at $1 \mu \mathrm{M}$ of the compound.

Table 3. Inhibitory activities of type III compounds against DNA gyrase from E. coli.

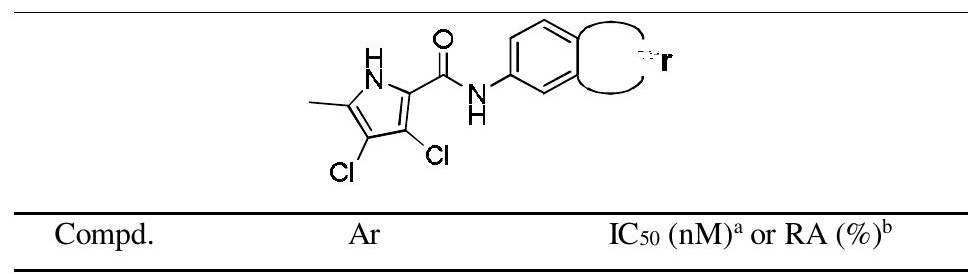




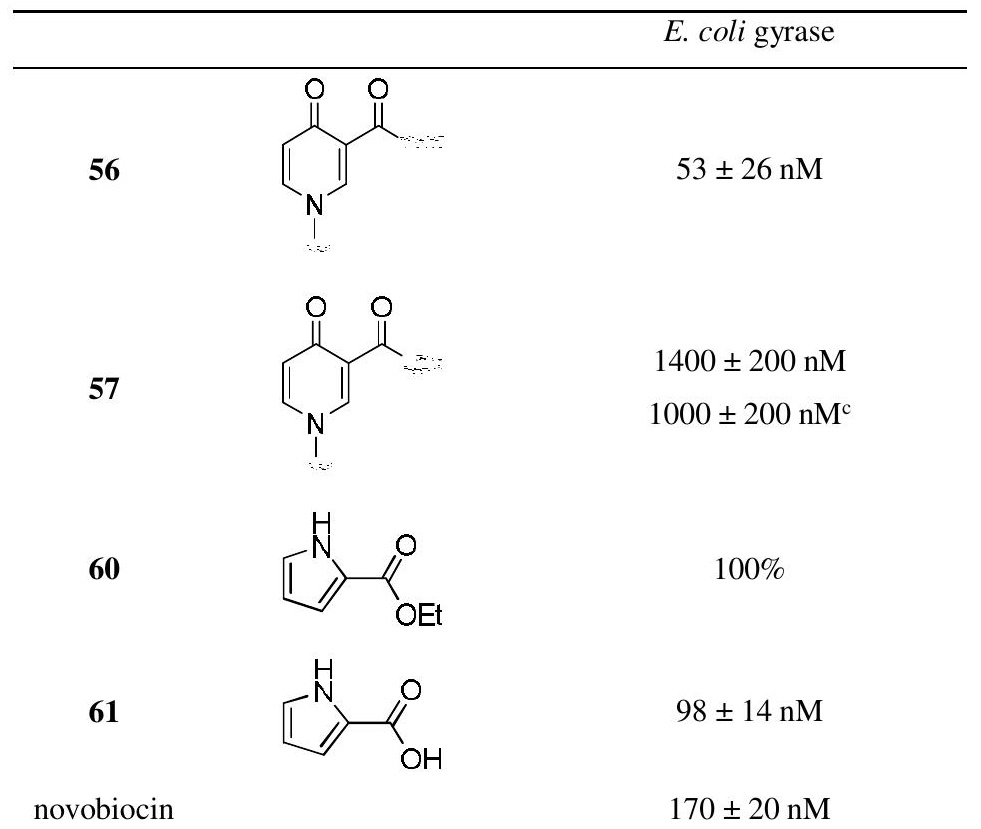

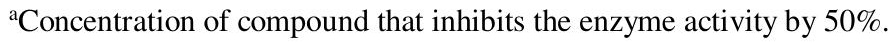

${ }^{\mathrm{b}}$ Residual activity of the enzyme at $1 \mu \mathrm{M}$ of the compound. ${ }^{\mathrm{c}}$ Result obtained with ATPase assay.

Table 4. Inhibitory activities of selected compounds against DNA gyrase from $S$. aureus and against topoisomerase IV from E. coli and $S$. aureus.

\begin{tabular}{|c|c|c|c|}
\hline \multirow{2}{*}{ Compd. } & \multicolumn{3}{|c|}{$\mathrm{IC}_{50}(\mathrm{nM})^{\mathrm{a}}$ or RA $(\%)^{\mathrm{b}}$} \\
\hline & S. aureus gyrase & E. coli topo IV & S. aureus topo IV \\
\hline $8 \mathbf{b}$ & $1008 \pm 300 \mathrm{nM}$ & $10000 \pm 2000 \mathrm{nM}$ & $7400 \pm 800 \mathrm{nM}$ \\
\hline $8 c$ & $26 \%$ & $88 \%$ & $830 \pm 120 \mathrm{nM}$ \\
\hline 8d & $68 \%$ & $99 \%$ & $79 \%$ \\
\hline $9 \mathbf{a}$ & $67 \%$ & $100 \%$ & $100 \%$ \\
\hline $9 \mathrm{~b}$ & $960 \pm 0.22 \mathrm{nM}$ & $7200 \pm 6700 \mathrm{nM}$ & $3700 \pm 2500 \mathrm{nM}$ \\
\hline $9 c$ & $99 \pm 11 \mathrm{nM}$ & $9100 \pm 2200 \mathrm{nM}$ & $690 \pm 30 \mathrm{nM}$ \\
\hline 9d & $31 \%$ & $15000 \pm 1000 \mathrm{nM}$ & $960 \pm 40 \mathrm{nM}$ \\
\hline $10 \mathbf{a}$ & $1600 \pm 300 \mathrm{nM}$ & $18000 \pm 1000 \mathrm{nM}$ & $3700 \pm 300 \mathrm{nM}$ \\
\hline $10 b$ & $49 \%$ & $89 \%$ & $94 \%$ \\
\hline 17 & $290 \pm 90 \mathrm{nM}$ & $16000 \pm 2 \mathrm{nM}$ & $4300 \pm 400 \mathrm{nM}$ \\
\hline 18 & $950 \pm 110 \mathrm{nM}$ & $90 \%$ & $94 \%$ \\
\hline 25 & $59 \%$ & $92 \%$ & $90 \%$ \\
\hline 39 & $55 \%$ & $98 \%$ & $81 \%$ \\
\hline 50 & $47 \%$ & $94 \%$ & $85 \%$ \\
\hline 57 & $90 \%$ & $92 \%$ & $100 \%$ \\
\hline novobiocin & $41 \pm 70 \mathrm{nM}$ & $11000 \pm 2000 \mathrm{nM}$ & $27000 \pm 7000 \mathrm{nM}$ \\
\hline
\end{tabular}


${ }^{\mathrm{a}}$ Concentration of compound that inhibits the enzyme activity by $50 \%$. ${ }^{\mathrm{b}}$ Residual activity

of the enzyme at $1 \mu \mathrm{M}$ of the compound.

Antibacterial Activity. Antibacterial activities of the prepared inhibitors were evaluated against the ESKAPE panel (Enterococcus faecium ATCC 35667, Staphylococcus aureus ATCC 29213, Klebsiella pneumoniae $\quad$ ATCC $\quad 700603$, Acinetobacter baumannii $\quad$ ATCC 19606, Pseudomonas aeruginosa ATCC27853, and Enterobacter aerogenes ATCC 13408). All the compounds were additionally tested against wild-type E. coli ATCC 25922 and two E. coli mutant strains, JD17464 and JW5503. E. coli JD17464 is an $\operatorname{lpxC}$ deletion mutant with impaired outer membrane, while E. coli JW5503 is a tolC deletion mutant with defective efflux pump. Sixteen compounds were also evaluated against E. faecalis (ATCC 29212). The results are presented in Table $1 \mathrm{~S}$ and Table $2 \mathrm{~S}$ (Supporting information) as growth inhibition (\%). Minimum inhibitory concentrations (MICs) were determined for compounds that inhibited one or more bacterial strains by more than $60 \%$ (Tables 5 and 6).

Overall, compounds displayed much stronger inhibition of Gram-positive than Gram-negative bacteria. Altogether five compounds $(\mathbf{2 4}, \mathbf{2 5}, \mathbf{4 3 b}, \mathbf{5 0}$ and 57) inhibited the growth of E. faecalis by more than $85 \%$ at $50 \mu \mathrm{M}$ concentration (Table 1S). Compound 25 displayed a better antibacterial activity $(\mathrm{MIC}=6.25 \mu \mathrm{M})$ than the corresponding hydrazide derivative $24(\mathrm{MIC}=$ $12.5 \mu \mathrm{M})$ (Table 5), probably because it is able to make stronger contacts with Arg136 through its 1,3,4-oxadiazol-2-thione ring on the right-hand side. Additionally, lower polarity of compound 25 compared to the more polar hydrazide $\mathbf{2 4}$ (see ChemGPS analysis below [31]) is believed to favour the permeation into the bacterial cells. Four compounds (7c, 8c, 25 and 57) inhibited the growth of E. faecium by more than $60 \%$ and two compounds (50 and 57) inhibited the growth of S. aureus by more than $95 \%$ at $50 \mu \mathrm{M}$ concentration (Table 1S). Of particular interest was the quinolone $\mathbf{5 7}$ that inhibited all the tested Gram-positive strains by more than $95 \%$, with excellent MIC values of $0.78 \mu \mathrm{M}$ against $S$. aureus, and of $1.56 \mu \mathrm{M}$ against $E$. faecalis and E. faecium (Table 5). This result is especially interesting, since this compound did not possess strong activity against DNA gyrase (E. coli $\mathrm{IC}_{50}=1.4 \mu \mathrm{M}, S$. aureus $\left.\mathrm{RA}=90 \%\right)$ or topoisomerase $\mathrm{IV}($ E. coli $\mathrm{RA}=92 \%$, S. aureus RA $=100 \%$ ) enzymes, which could suggest a different mode of action for this compound. Interestingly, the zwitterionic compounds $\mathbf{9 b - d}$ and 17, which were the most potent in the enzymatic assays, did not show good antibacterial activities. Probably these compounds have 
difficulties with passing through bacterial cell wall due to the presence of two charged functional groups.

None of the compounds displayed significant inhibition of the wild-type E. coli but six of them $(\mathbf{1 0 a}, \mathbf{1 0 b}, \mathbf{1 8}, \mathbf{4 3 b}, \mathbf{5 0}$ and $\mathbf{6 1})$ showed more than $80 \%$ inhibition of E. coli tolC deletion mutant with defective efflux pump at $50 \mu \mathrm{M}$ concentration (Table $2 \mathrm{~S}$ ), and for those compounds the MIC values were between 3.13 and $25 \mu \mathrm{M}$ (Table 6). These results indicate that some compounds are subject to bacterial efflux, which is likely the main reason for their weaker activity against wildtype Gram-negative bacteria. Among the compounds that were active against E. coli tolC deletion mutant, three derivatives belonging to type I series (10a, 10b and 18) share similar structures, i.e. a positively charged amino group-containing heterocycles on the central benzene ring and a methyl carboxylate group on the right-hand side. This is in agreement with the recent reports, that the overall positive charge of a molecule is an important factor to achieve higher level of accumulation in E. coli [32]. Our results also confirm that the presence of a positively charged amino group alone is not sufficient to obtain compounds with high accumulation in E. coli, but that other parameters should be taken into account while designing antibacterials with Gram-negative activity, such as high rigidity, low globularity and high amphiphilic moment [33]. In addition to type I compounds 10a, 10b and 18, other three compounds that significantly inhibited E. coli tolC deletion mutant were the nitrile 43b $(\mathrm{MIC}=12.5 \mu \mathrm{M})$, the 5-oxotetrazole derivative $50(\mathrm{MIC}=3.13 \mu \mathrm{M})$ and the indole derivative $61(\mathrm{MIC}=12.5 \mu \mathrm{M})($ Table 6).

Table 5. Minimum inhibitory concentrations (MICs) of compounds 7c, 8c, 24, 25, 43b, 50, and 57 against E. faecalis (ATCC 29212), E. faecium (ATCC 35667) and S. aureus (ATCC 29213).

\begin{tabular}{cccc}
\hline \multirow{2}{*}{ Compd. } & \multicolumn{3}{c}{ MIC $(\mu \mathrm{M})^{\mathrm{a}}$} \\
\cline { 2 - 4 } & E. faecalis $($ ATCC 29212) & E. faecium $($ ATCC 35667) & S. aureus $($ ATCC 29213) \\
\hline $\mathbf{7 c}$ & n.d. $^{\mathrm{b}}$ & $>125$ & n.d. \\
$\mathbf{8 c}$ & n.d. & $>125$ & n.d. \\
$\mathbf{2 4}$ & 12.5 & n.d. & n.d. \\
$\mathbf{2 5}$ & 6.25 & $>125$ & n.d. \\
$\mathbf{4 3 b}$ & 25 & n.d. & n.d. \\
$\mathbf{5 0}$ & 12.5 & n.d. & 50 \\
$\mathbf{5 7}$ & 1.56 & 1.56 & 0.78 \\
\hline
\end{tabular}

${ }^{a}$ MIC (minimum inhibitory concentration that inhibits the growth of bacteria by $\ddot{i}$ 90\%) values against E. faecalis, E. faecium and $S$. aureus. Ciprofloxacin was used as a positive control for E. faecalis and S. aureus at MIC of 3.02 and 1.51 $\mu \mathrm{M}$, respectively. For E faecium linezolid was used as positive control at MIC of $11.86 \mu \mathrm{M}$. ${ }^{\mathrm{b}}$ Not determined. 
Table 6. Minimum inhibitory concentrations (MICs) of compounds $\mathbf{1 0 a}, \mathbf{1 0 b}, \mathbf{1 8}, \mathbf{4 3 b}, \mathbf{5 0}$ and 61 against E. coli (JW5503).

\begin{tabular}{cc}
\hline \multirow{2}{*}{ Compd. } & ${\text { MIC }(\mu \mathrm{M})^{\mathrm{a}}}^{\mathrm{a}}$ \\
\cline { 2 - 2 } $\mathbf{1 0 a}$ & 6.25 \\
$\mathbf{1 0 b}$ & 6.25 \\
$\mathbf{1 8}$ & 25 \\
$\mathbf{4 3 b}$ & 12.5 \\
$\mathbf{5 0}$ & 3.13 \\
& 12.5 \\
$\mathbf{6 1}$ & \\
\hline aMIC (minimum inhibitory concentration that \\
inhibits the growth of bacteria by ï 90\%) values \\
against $E$. coli JW5503 (tolC deletion mutant). \\
Ciprofloxacin was used as a positive control at \\
a MIC of $0.015 \mu \mathrm{M}$.
\end{tabular}

Further Biological Evaluation of Compound 57. Overall, compound 57 was selected as the most promising compound, since it displayed the lowest MIC values against Gram-positive bacteria. Thus, for this compound we determined the MIC values against a panel of additional Gram-positive and Gram-negative bacterial strains (Table 7). Compound 57 displayed promising MIC values of $0.72 \mu \mathrm{M}$ against vancomycin-resistant E. faecium (VRE, ATCC 700221) and Streptococcus pyogenes (ATCC 19653), and MIC values of $2.5 \mu \mathrm{M}$ against methicillin-resistant S. aureus (MRSA, ATCC 43300), ciprofloxacin non-susceptible and extremely drug resistant strain of $S$. aureus (MRSA VISA, ATCC 700699), and S. aureus (ATCC 25923) strains. The activity against methicillin-resistant S. aureus (MRSA, ATCC 43300) in the presence of 50\% inactivated human blood serum was also promising, with MIC value of $32 \mu \mathrm{M}$. Compound 57 was additionally evaluated against the wild-type E. coli strains ATCC 25922 and MG1655 in the presence of efflux pump substrate phenylalanine-arginine -naphthylamide (PA N), and the MIC values were $2.3 \mu \mathrm{M}$ and $2.5 \mu \mathrm{M}$, respectively. These results indicate that the inactivity against wild-type Gram-negative organisms is probably associated with efflux. Also, MIC values against $P$. aeruginosa (ATCC 27853), K. pneumoniae (ATCC 10031), Shigella flexneri (HNCMB 20018) and Salmonella enterica (LT2) were determined but were above $32 \mu \mathrm{M}$ (Table 7). 
Given the quinolone substructure of compound 57, we decided to perform additional experiments on $E$. coli and $K$. pneumoniae strains that possess mutations in the key amino acids of the GyrA and GyrB binding sites, to investigate whether this compound binds preferably to the subunit A or to the subunit $\mathrm{B}$ of the enzyme (Table 8). The results indicate that neither mutations at GyrA, nor mutations at GyrB or ParC influence the MIC values of compound 57. This suggests a different mode of action of compound $\mathbf{5 7}$.

To further investigate the mode of action of compound $\mathbf{5 7}$, we determined its inhibitory activity on E. coli DNA gyrase using an ATP competitive assay (Table 3). This test measures the competitive action of compounds against ATP and therefore provides experimental evidence that compounds bind to the ATP binding pocket of the enzyme, located on the GyrB subunit. Since the activity of compound 57, determined with ATPase assay $\left(\mathrm{IC}_{50}=1.0 \mu \mathrm{M}\right)$, was similar to the activity determined with supercoiling assay $\left(\mathrm{IC}_{50}=1.4 \mu \mathrm{M}\right)$, its inhibition of DNA gyrase is most likely due to binding to GyrB.

The possibility of compound $\mathbf{5 7}$ to bind to the fluoroquinolone binding site on the GyrA subunit was additionally studied with molecular docking (Figure 2S, Supporting Information). The docking pose of compound 57 in the $S$. aureus DNA gyrase (PDB entry: 2XCT [34]), superimposed with the pose of ciprofloxacin, shows that compound $\mathbf{5 7}$ adopts a different conformation as ciprofloxacin. In particular, compound $\mathbf{5 7}$ is not able to establish similar contacts with $\mathrm{Mn}^{2+}$, which are crucial for the binding. The most likely reason is that the pyrrolamide portion of the compounds is creating steric clashes, which prevent the compound to adopt the same orientation as ciprofloxacin.

Table 7. Minimum inhibitory concentrations (MICs) of compound 57 against additional Grampositive and Gram-negative bacterial strains.

\begin{tabular}{lr}
\hline Compound $\mathbf{5 7}$ & MIC $(\mu$ ) \\
\hline Gram-positive bacteria & 0.72 \\
E. faecium (VRE, ATCC 700221) & 0.72 \\
Streptococcus pyogenes (ATCC 19653) & 2.5 \\
S. aureus (MRSA, ATCC 43300) & 2.5 \\
S. aureus (MRSA VISA ATCC 700699) &
\end{tabular}




\begin{tabular}{|c|c|}
\hline $\begin{array}{l}\text { S. aureus (MRSA, ATCC 43300) + 50\% } \\
\text { inactivated human blood serum }\end{array}$ & 32 \\
\hline S. aureus (ATCC 25923) & 2.5 \\
\hline \multicolumn{2}{|l|}{ Gram-negative bacteria } \\
\hline E. coli (ATCC 25922) & $>32$ \\
\hline E. coli $($ ATCC 25922) $+50 \mu \mathrm{g} / \mathrm{mL} \mathrm{PA} \mathrm{N}$ & 2.3 \\
\hline E. coli $(\mathrm{MG} 1655)+50 \mu \mathrm{g} / \mathrm{mL}$ PA N & 2.5 \\
\hline P. aeruginosa (ATCC 27853) & $>32$ \\
\hline K. pneumoniae (ATCC 10031) & $>32$ \\
\hline S. flexneri (HNCMB 20018) & $>32$ \\
\hline S. enterica (LT2) & $>32$ \\
\hline
\end{tabular}

${ }^{a} \mathrm{MIC}$ (minimum inhibitory concentration that inhibits the growth of bacteria by $>90 \%$ ) measurements were performed according to the EUCAST guidelines in three independent measurements.

Table 8. Minimum inhibitory concentrations (MICs) of compound 57 against Gram-negative bacterial strains with mutated amino acids in the GyrA or GyrB active sites in the presence of phenylalanine-arginine -naphthylamide (PA N).

\begin{tabular}{|c|c|}
\hline \multirow{2}{*}{ Strain } & $\operatorname{MIC}(\mu \mathrm{M})^{\mathrm{a}}$ \\
\hline & Compd. $57+50 \mu \mathrm{g} / \mathrm{ml}$ PA $\mathrm{N}$ \\
\hline E. coli MG1655 (wild-type) & 2.5 \\
\hline E. coli MG1655 GyrB R136C & 2.5 \\
\hline E. coli MG1655 GyrA S83L & 2.5 \\
\hline E. coli MG1655 GyrA S83L, D87N & 2.5 \\
\hline E. coli MG1655 GyrA S83L, D87N; ParC S80I & 2.5 \\
\hline E. coli MG1655 GyrA S83L, D87N; ParC S80I, E84G & 2.5 \\
\hline K. pneumoniae (ATCC 10031) (wild-type) & $1.2^{\mathrm{b}}$ \\
\hline K. pneumoniae (ATCC 10031) GyrA S83F & $1.2^{\mathrm{b}}$ \\
\hline K. pneumoniae (ATCC 10031) GyrA S83Y & $1.2^{\mathrm{b}}$ \\
\hline K. pneumoniae (ATCC 10031) GyrA S83L & $1.2^{\mathrm{b}}$ \\
\hline K. pneumoniae (ATCC 10031) GyrA S83F, D87G & $2.5^{\mathrm{b}}$ \\
\hline K. pneumoniae (ATCC 10031) GyrA S83F, D87G; ParC S80I & $1.2^{\mathrm{b}}$ \\
\hline K. pneumoniae (ATCC 10031) GyrA S83F, D87G; ParC S80I, E84G & $1.2^{\mathrm{b}}$ \\
\hline \multicolumn{2}{|c|}{$\begin{array}{l}\text { a MIC (minimum inhibitory concentration that inhibits the growth of bacteria by > 90\%) measurements } \\
\text { were performed according to the EUCAST guidelines in } 3 \text { independent measurements. }{ }^{\mathrm{b}} \mathrm{MIC} \text { values were } \\
\text { determined in the presence of } 10 \mu \mathrm{g} / \mathrm{ml} \mathrm{PA} \text { N. Ciprofloxacin was used as a positive control. MIC values } \\
\text { of ciprofloxacin against } E \text {. coli MG1655 GyrB R136C and } E \text {. coli MG1655 GyrA S83L were } 0.01 \mu \mathrm{M} \text {, } \\
\text { against } E \text {. coli MG1655 GyrA S83L, D87N was } 0.19 \mu \mathrm{M} \text {, against } E \text {. coli MG1655 GyrA S83L, D87N; } \\
\text { ParC S80I was } 8 \mu \mathrm{M} \text { and against } E \text {. coli MG1655 GyrA S83L, D87N; ParC S80I, E84G was >32 } \mu \mathrm{M} \text {. }\end{array}$} \\
\hline
\end{tabular}


Physicochemical Properties of the Tested Compounds. To investigate the physicochemical space that our molecules are populating, and to link this information to their antibacterial activities, we performed a chemographic mapping of all the synthesised compounds using the ChemGPS$\mathrm{NP}_{\text {Web }}$ tool [35] (Figure 5). ChemGPS-NP ${ }_{\text {Web }}$ service is a useful tool that could provide valuable information for designing compounds with broad-spectrum antibacterial activity [36]. For the compounds that were prepared as L- and D-enantiomers, only the L-enantiomers $(\mathbf{7 c}, 8 \mathbf{8 c}, 9 \mathbf{c}$ and 10a) were taken into consideration. For each compound, eight principal components (PCs) were generated (PC1-8, Table 3S of Supporting information). Each PC describes different physicochemical properties and, among those, the first three PCs (PC1-3) are the most significant. PC1 accounts for size, shape and polarizability, PC2 comprises aromaticity and conjugation properties, PC3 includes lipophilicity, polarity and H-bond formation capacity [37]. A description for PC4, PC5, PC6, PC7 and PC8 is given in Table 3S of Supporting information. We plotted our compounds in a 3D diagram, setting PC1, PC2 and PC3 as the $\mathrm{x}, \mathrm{y}$ and $\mathrm{z}$ axes. In this study, the value of PC1 correlates with the size of the compounds, PC2 correlates with the number of aromatic rings and the degree of conjugation in the molecule, while the value of PC3 correlates with their lipophilicity (cLogP). The chemographic plot shows that our compounds can be divided by PC3 into three groups: lipohphilic derivatives (red-yellow spheres), moderately lipophilic derivatives (green spheres) and more polar compounds (blue spheres). Compounds 24, 25, 43b, 50 and 57 that showed the most promising antibacterial activities against Gram-positive bacteria all possessed moderately low values of PC3 (cLogP values were 1.07, 2.42, 1.34, 1.74 and 2.83, respectively) and are represented by green-blue colour in the graph. Additionally, these compounds stay on the lower side of PC1 (MW = 456, 497, 351, 353 and 408, respectively), indicating that they are smallsized and less bulky than type I compounds 7a-7c, 8a-c, 15 and $\mathbf{1 6}(\mathrm{MW}=658,583,597,644$, 569, 583, 569 and 555, respectively). The zwitterionic compounds 9b, 9c and 17, which were the most potent in the enzymatic assays, show relatively low lipophilicity (cLogP $=1.01,1.31$ and 0.89 , respectively) and are medium sized (medium value of PC1, MW =490-510). Most probable reason for their inactivity in bacteria is the simultaneous presence of two charged groups, which makes their entry into bacterial cell more problematic. 


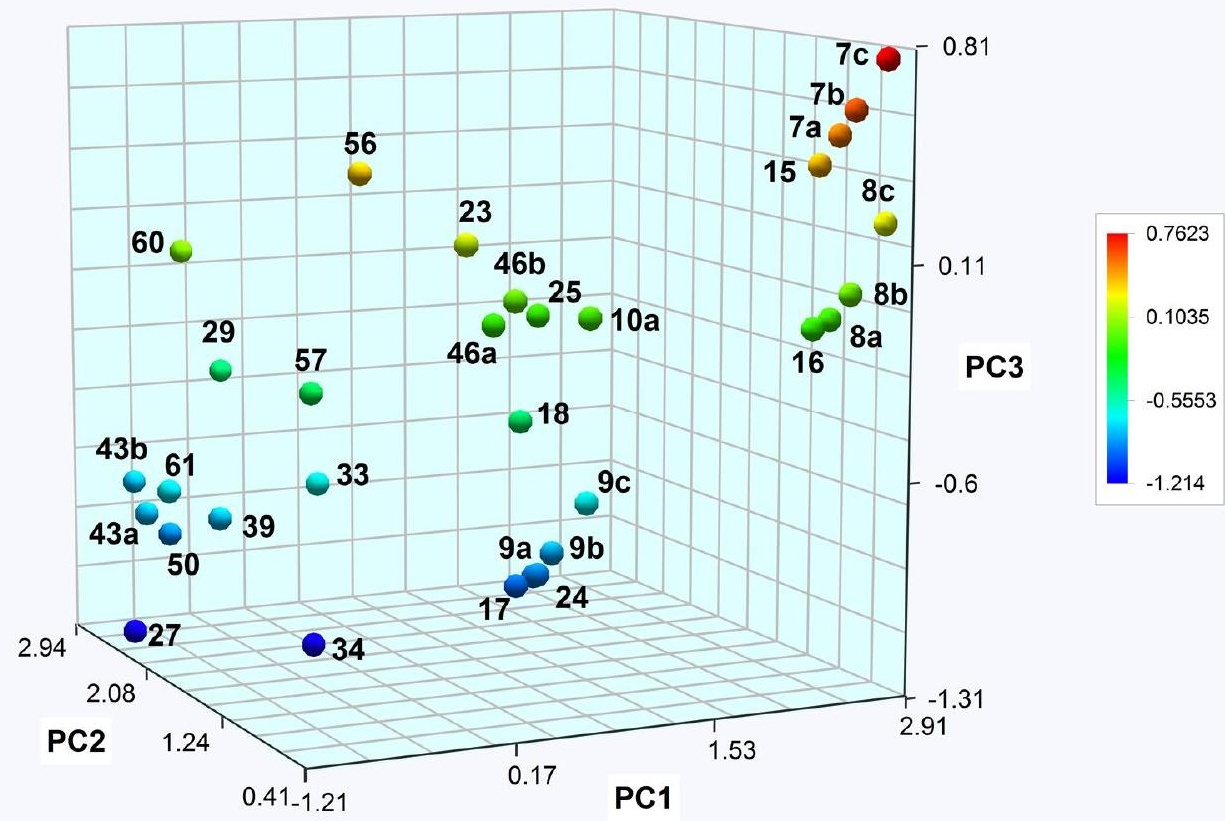

Figure 5. Chemographic plot of the synthesised compounds. In the colour map displayed on the right, the red-yellow band represents the lipophilic region, the green band represents the moderately lipophilic region and the blue band represents the more polar region. The values of cLogP described in the text were calculated by ChemOffice 2016 [38]. The graph was prepared by Teraplot [39].

We performed a computational study on Lipinski's rule of five parameters for the most promising compounds 24, 25, 43b, 50 and 57. The study was carried out using SwissADME free tool [40]. Lipinski's parameters (molecular weight, MLOGP [41], number of H-bond donors and H-bond acceptors) and calculated water solubility $(\log S$ [42]) are reported in Table 9. All selected compounds complied to Lipinski's rules.

Table 9. Lipinski's parameters (molecular weight, MLOGP, number of H-bond donors and H-bond acceptors) and predicted water solubility (LogS) of compounds 24, 25, 43b, 50 and 57.

\begin{tabular}{cccccc}
\hline Compd. & MW (g/mol) & MLOGP & H-bond acceptor & H-bond donor & LogS \\
\hline $\mathbf{2 4}$ & 456.32 & 1.13 & 5 & 5 & -3.91 \\
$\mathbf{2 5}$ & 498.38 & 1.57 & 5 & 4 & -5.33
\end{tabular}




\begin{tabular}{llllll}
$\mathbf{4 3 b}$ & 351.19 & 1.08 & 3 & 3 & -3.61 \\
$\mathbf{5 0}$ & 353.16 & 2.41 & 4 & 3 & -4.32 \\
$\mathbf{5 7}$ & 408.24 & 1.74 & 4 & 3 & -4.95 \\
\hline
\end{tabular}

In vitro Cytotoxicity Measurements. Cytotoxicity of compounds 17, 25 and 56, representatives of type I, type II and type III structures, was determined in a MTS (3-(4,5-dimethylthiazol-2-yl)-5(3-carboxymethoxyphenyl)-2-(4-sulfophenyl)-2H-tetrazolium) assay on human HepG2 cells (hepatocellular carcinoma cells) and on HUVEC cells (human umbilical vein endothelial cells). The decrease in cell proliferation after the treatment with compounds was compared to the decrease of etoposide-treated cells at $50 \mu \mathrm{M}$ concentration. None of the compounds showed significant cytotoxic activity against HepG2 cells and HUVEC cells at $50 \mu \mathrm{M}$ concentration (Table 10).

Table 10. Cytotoxic activity of compounds 17, 25 and 56 against HepG2 and HUVEC cell lines.

\begin{tabular}{ccc}
\hline \multirow{2}{*}{ Compd. } & \multicolumn{2}{c}{ \% viability $^{\mathrm{a}}$} \\
\cline { 2 - 3 } & HepG2 cell line & HUVEC cell line \\
\hline $\mathbf{1 7}$ & $46 \%$ & $130 \%$ \\
$\mathbf{2 5}$ & $80 \%$ & $85 \%$ \\
$\mathbf{5 6}$ & $90 \%$ & $88 \%$ \\
Etoposide & IC $_{50}=20 \pm 1.6 \mu \mathrm{M}$ & IC $_{50}=5.2 \pm 2.8 \mu \mathrm{M}$ \\
\hline a Determined in MTS (3-(4,5-dimethylthiazol-2-yl)-5-(3-carboxymethoxyphenyl)-2- \\
(4-sulfophenyl)-2H-tetrazolium) assay
\end{tabular}

\section{CONCLUSION}

Given the rising bacterial resistance to existing antibacterials, there is a constant need for new drugs acting through the so-far less exploited mechanisms. Thus, we have designed and prepared a series of new $\mathrm{N}$-phenylpyrrolamides as DNA gyrase and topoisomerase IV inhibitors interacting with the ATP binding site. The most potent DNA gyrase and topo IV inhibitors of the series, 9c and 9d, contained a carboxylic moiety on the right-hand side of the molecules and a piperidin-4-yloxy substituent on the central benzene ring, and displayed excellent $\mathrm{IC}_{50}$ values of $9.9 \mathrm{nM}$ and $6.9 \mathrm{nM}$ against $E$. coli DNA gyrase, respectively. The $\mathrm{IC}_{50}$ value of 9c against $S$. aureus topo IV was 0.69 $\mu \mathrm{M}$. Several compounds displayed antibacterial activity against Gram-positive strains. The most 
potent was quinolone derivative $\mathbf{5 7}$ that inhibited the growth of several bacteria with excellent MIC values: E. faecalis $(\mathrm{MIC}=1.56 \mu \mathrm{M})$, E. faecium $(\mathrm{MIC}=1.56 \mu \mathrm{M})$, S. aureus $(\mathrm{MIC}=0.78 \mu \mathrm{M})$, $S$. pyogenes $(\mathrm{MIC}=0.72 \mu \mathrm{M}), \operatorname{MRSA}(\mathrm{MIC}=2.5 \mu \mathrm{M})$ and extremely drug resistant strain of $S$. aureus (MRSA VISA) $(\mathrm{MIC}=2.5 \mu \mathrm{M})$. Compound 57 displayed the MIC value of $32 \mu \mathrm{M}$ against MRSA in the presence of inactivated human blood serum, and thus represents a promising scaffold for the preparation of further optimized compounds. Since the on-target activity of compound $\mathbf{5 7}$ (E. coli DNA gyrase $\mathrm{IC}_{50}=1.4 \mu \mathrm{M}$ ) cannot fully explain its good antibacterial activity, further studies are needed to confirm its mode of action. Although none of the compounds possessed significant activities against wild-type Gram-negative bacteria, some of the compounds were active against the E. coli mutant strain with defective efflux pump, e.g. compound $\mathbf{5 0}$ with MIC of 3.13 $\mu \mathrm{M}$, indicating that efflux mechanisms are a considerable factor counteracting antibacterial activity of our compounds. To accumulate inside Gram-negative bacteria, small molecules thus need to penetrate into bacteria faster than they are pumped out. To achieve this, the physicochemical properties of compounds need to be carefully optimised. Chemographic mapping of our compounds presented herein provides useful information in the search of a more optimal physicochemical space that would result in the discovery of compounds with broad-spectrum antibacterial activities.

\section{EXPERIMENTAL SECTION}

\section{Determination of Inhibitory Activities on $E$. coli and $S$. aureus DNA Gyrase and} Topoisomerase IV. The assay for the determination of $\mathrm{IC}_{50}$ values was performed according to previously reported procedures [13]. An ATPase assay on E. coli DNA gyrase for compound 57 was performed by Inspiralis according to reported procedure [17].

\section{Determination of Antibacterial Activity.}

Clinical microbiology control strains of A. baumannii (ATCC19606), E. aerogenes (ATCC13408), E. faecalis (ATCC 29212), E. faecium (ATCC 35667), E. faecium (ATCC 700221), E. coli (ATCC 25922), K. pnemoniae (ATCC 700603 and ATCC 10031), P. aeruginosa (ATCC 27853), and $S$. aureus (ATCC 25913) and S. aureus (MRSA VISA ATCC 700699) were obtained from Microbiologics Inc. (St. Cloud, MN). E. coli MG1655 originated from the laboratory collection of Dr. Csaba Pál. GyrA, GyrB, and ParC mutant strains of E. coli MG1655 and K. pneumoniae 
ATCC10031 were constructed using pORTMAGE recombineering technology [43]. S. flexneri (HNCMB 20018), S. aureus (MRSA, ATCC 43300), S. aureus (ATCC 25923) and Streptococcus pyogenes (ATCC 19653) were obtained from the University of Szeged (Hungary). S. enterica (LT2) was originated from the laboratory collection of Donald L. Court (USA). Single-gene knockout mutant strains of E. coli JW5503 (tolC knock-out) and JD17464 (lpxC knock-out) were obtained from the NBRP E.coli collection at the National Institute of Genetics (NIG, Japan [44]). To determine antibacterial activity, broth microdilution assays in 96-well plates were carried out by following the Clinical Laboratory Standard Institute guidelines the Clinical Laboratory Standard Institute guidelines [45]. For selected compounds, MIC values were determined by dose-response experiments (reported values are from at least two independent experiments, each with three replicates per concentration). In the experiments with the efflux inhibitor, the assay media was supplemented with PA N (50 $\mu \mathrm{g} / \mathrm{mL}$ PA N, Sigma-Aldrich, Switzerland). Human blood serum was purchased from Sigma-Aldrich.

\section{In vitro cytotoxicity measurements.}

Cytotoxicity of compounds 17, 25 and $\mathbf{5 6}$ was determined in MTS (3-(4,5-dimethylthiazol-2-yl)5-(3-carboxymethoxyphenyl)-2-(4-sulfophenyl)-2H-tetrazolium) assay [46] with a few modifications. HepG2 (ATCC) and HUVEC (ATCC) cells were cultured in Eagle's MEM medium supplemented with L-glutamine (2 $\mathrm{mM})$, penicillin/streptomycin $(100 \mathrm{UI} / \mathrm{mL} / 100 \mu \mathrm{g} / \mathrm{mL})$, and $10 \%$ FBS. The cells were incubated in a humidified atmosphere with $5 \% \mathrm{CO} 2$ at $37{ }^{\circ} \mathrm{C}$.

The cells were seeded in 96-well plates at densities 2000 cells per well in $100 \mu \mathrm{L}$ of growth medium and incubated for $24 \mathrm{~h}$ to attach onto the wells. $50 \mu \mathrm{L}$ of compounds at $50 \mu \mathrm{M}$ concentration in DMSO (0.5\% final concentration) were added and incubated for $72 \mathrm{~h}$. After $72 \mathrm{~h} 10 \mu \mathrm{L}$ of CellTiter96 ${ }^{\circledR}$ Aqueous One Solution Reagent, (Promega) [47] was added to determine the number of viable cells. The plates were incubated for another $3 \mathrm{~h}$ and absorbance $(490 \mathrm{~nm})$ was read with a BioTek's Synergy H4 microplate reader. Etoposide [ $\mathrm{IC}_{50}=20.1 \mu \mathrm{M}$ (Ref. [48]: $30.2 \mu \mathrm{M}$ ) for HepG2 and $\mathrm{IC}_{50}=5.21 \mu \mathrm{M}$ (Ref. [49]: $1.25 \mu \mathrm{M}$ ) for HUVEC] at $50 \mu \mathrm{M}$ concentration was used as a positive control and $0.5 \%$ DMSO as a vehicle control. To determine cell viability, results from the wells that contained test compound-treated cells were compared to those with cells incubated in $0.5 \%$ DMSO. Independent experiments were run in triplicate and repeated two times. Statistical 
significance $(\mathrm{p}<0.05)$ was calculated with two-tailed Welch's $t$-test between treated groups and DMSO.

\section{Molecular Modelling.}

Protein and ligand preparation and ligand docking were performed using GOLD Suite v5.4 [50] according to previously reported procedures [14]. Detailed procedures can be found in Supporting Informantion.

Chemistry. Chemicals were obtained from Acros Organics (Geel, Belgium), Sigma-Aldrich (St. Louis, MO, USA) and Apollo Scientific (Stockport, UK) and used without further purification. Analytical TLC was performed on silica gel Merck $60 \mathrm{~F}_{254}$ plates $(0.25 \mathrm{~mm})$, using visualization with UV light and spray reagents. Column chromatography was carried out on silica gel 60 (particle size 240-400 mesh). HPLC analyses were performed on an Agilent Technologies 1100 instrument (Agilent Technologies, Santa Clara, CA, USA) with a G1365B UV-Vis detector, a G1316A thermostat, a G1313A autosampler, and a ChemStation Data System or on a Thermo Scientific Dionex Ultimate 3000 Binary Rapid Separation LC System (Thermo Fisher Scientific, Waltham, MA, USA) with an autosampler, a binary pump system, a photodiode array detector, a thermostated column compartment, and a Chromeleon Chromatography Data System. The columns used were Agilent Eclipse C18 column (5 m, $4.6 \times 150$ mm) or Phenomenex Luna C18 column (5 m, 4.6 $\times 250 \mathrm{~mm})$, with a flow rate of $1.0 \mathrm{~mL} / \mathrm{min}$. The eluent consisted of trifluoroacetic acid $(0.1 \%$ in water) or $20 \mathrm{mM}$ phosphate buffer ( $\mathrm{pH} \mathrm{6.8)}$ as solvent $\mathrm{A}$ and acetonitrile as solvent B. Melting points were determined on a Reichert hot stage microscope and are uncorrected. ${ }^{1} \mathrm{H}$ and ${ }^{13} \mathrm{C}$ NMR spectra were recorded at 400 and $100 \mathrm{MHz}$, respectively, on a Bruker AVANCE III 400 spectrometer (Bruker Corporation, Billerica, MA, USA) in DMSO- $d_{6}, \mathrm{CDCl}_{3}$ or acetone- $d_{6}$ solutions, with TMS as the internal standard. IR spectra were recorded on a Thermo Nicolet Nexus 470 ESP FT-IR spectrometer (Thermo Fisher Scientific, Waltham, MA, USA). Mass spectra were obtained using a Q-TOF Premier mass spectrometer (Micromass, Waters, Manchester, UK) or ADVION expression CMSL mass spectrometer (Advion Inc., Ithaca, USA). Optical rotations were measured on a Perkin-Elmer $241 \mathrm{MC}$ polarimeter. The reported values for specific rotation are 
average values of 10 successive measurements using an integration time of $5 \mathrm{~s}$. The purity of the tested compounds was $і ̈$ 95\% as established by HPLC.

\section{Synthetic Procedures.}

General procedure A. Synthesis of Compounds 3, 11 and 19 (with 3 as an Example). To a stirred solution of compound $2(3.08 \mathrm{~g}, 15.7 \mathrm{mmol})$ and triphenylphosphine $(5.50 \mathrm{~g}, 21.0 \mathrm{mmol})$ in anhydrous tetrahydrofuran (200 mL) 1-Boc-4-hydroxypiperidine (4.0 g, $19.9 \mathrm{mmol})$ was added and the mixture was stirred at rt for $10 \mathrm{~min}$. Diisopropyl azodicarboxylate (DIAD, $3.91 \mathrm{~mL}, 19.87$ mmol) was added dropwise and the mixture was stirred at $\mathrm{rt}$ for $15 \mathrm{~h}$ under argon atmosphere. The solvent was evaporated under reduced pressure and the crude product was purified with flash column chromatography using ethyl acetate/petroleum ether (1/2) as an eluent to give $\mathbf{3}$ (3.2 g) as yellow solid.

tert-Butyl 4-(5-(methoxycarbonyl)-2-nitrophenoxy)piperidine-1-carboxylate (3). Yellow solid; yield 54\% (3.2 g); mp 66-68 ${ }^{\circ} \mathrm{C}$; IR (ATR) = 2974, 1726, 1689, 1603, 1525, 1485, 1408, 1364, 1300, 1279, 1235, 1165, 1030, 749, $671 \mathrm{~cm}^{-1} .{ }^{1} \mathrm{H}$ NMR (400 MHz, $\left.\mathrm{CDCl}_{3}\right)$ : / = 1.49 (s, 9H, $\left.3 \times \mathrm{CH}_{3}\right), 1.84-1.99(\mathrm{~m}, 4 \mathrm{H}, 4 \times(\mathrm{CH}) \mathrm{CH}-\mathrm{O}-\mathrm{Ar}), 3.53-3.60(\mathrm{~m}, 4 \mathrm{H}, 4 \times \mathrm{CHNBoc}), 3.98(\mathrm{~s}, 3 \mathrm{H}$, $\left.\mathrm{COOCH}_{3}\right), 4.78-4.83$ (m, 1H, C$\left.-\mathrm{O}-\mathrm{Ar}\right), 7.70$ (dd,1H, $\left.{ }^{3} \mathrm{~J}=8.4 \mathrm{~Hz},{ }^{4} \mathrm{~J}=1.6 \mathrm{~Hz}, \mathrm{Ar}-\mathrm{H}-4\right), 7.75$ (d, $\left.{ }^{4} J=1.6 \mathrm{~Hz}, 1 \mathrm{H}, \mathrm{Ar}-\mathrm{H}-6\right), 7.83\left(\mathrm{~d}, 1 \mathrm{H},{ }^{3} J=8.4 \mathrm{~Hz}, \mathrm{Ar}-\mathrm{H}-3\right) .{ }^{13} \mathrm{C} \mathrm{NMR}\left(100 \mathrm{MHz}, \mathrm{CDCl}_{3}\right) / 28.44$ $\left(3 \times \underline{\mathrm{CH}}_{3}\right), 29.99,39.89,52.92,74.00,79.78,116.75,121.62,125.48,134.66,143.63,150.11$, 154.73, $165.23\left(\underline{\left.\mathrm{COOCH}_{3}\right)}\right.$. MS (ESI) $\mathrm{m} / \mathrm{z}=331.37([\mathrm{M}+\mathrm{H}]+)$, HRMS for $\mathrm{C}_{18} \mathrm{H}_{25} \mathrm{~N}_{2} \mathrm{O}_{7}$ : calculated 381.1656 , found 381.1662 .

General procedure B. Synthesis of Compounds 4, 12, 20 (with 4 as an Example). To the solution of compound 3 (2.90 g, $7.63 \mathrm{mmol})$ in methanol (50 mL) $1 \mathrm{M} \mathrm{NaOH}(30.4 \mathrm{~mL}, 30.4 \mathrm{mmol})$ was added. The mixture was stirred at $\mathrm{rt}$ for $15 \mathrm{~h}$. The solvent was removed under reduced pressure, EtOAc $(20 \mathrm{~mL})$ and $1 \mathrm{M} \mathrm{HCl}(20 \mathrm{~mL})$ were added to the residue. The organic phase was washed with brine $(2 \times 20 \mathrm{~mL})$, dried over $\mathrm{Na}_{2} \mathrm{SO}_{4}$, filtered and the solvent removed under reduced pressure to afford $4(2.60 \mathrm{~g})$ as white solid.

3-((1-(tert-Butoxycarbonyl)piperidin-4-yl)oxy)-4-nitrobenzoic acid (4). White solid; yield 93\% (2.60 g); mp 158-161 ${ }^{\circ} \mathrm{C}$; IR (ATR) = 2963, 2866, 1720, 1689, 1523, 1406, 1298, 1237 , 1223, 1165, 1120, 1033, 841, 772, $746 \mathrm{~cm}^{-1} .{ }^{1} \mathrm{H}$ NMR $\left(400 \mathrm{MHz}, \mathrm{CDCl}_{3}\right): /=1.50$ (s, 9H, $3 \times$

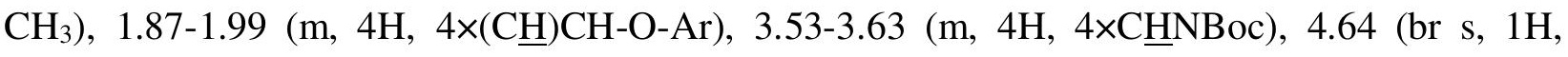


$\mathrm{COOH}), 4.80-4.85$ (m, 1H, Cㅌ-O-Ar), 7.77-7.81 (m, 2H, Ar-H-2,6), 7.84-7.86 (d, 1H, ${ }^{3} J=8.3 \mathrm{~Hz}$ Ar-H-5). ${ }^{13} \mathrm{C}$ NMR (100 MHz, $\left.\mathrm{CDCl}_{3}\right) / 28.45$ (3 $\left.\times \underline{\mathrm{CH}}_{3}\right), 29.95,39.91,73.99,80.11,117.12$, 122.26, 125.55, 133.79, 144.12, 150.09, 154.91, $168.62(\underline{\mathrm{COOH}}) . \mathrm{MS}(\mathrm{ESI}) \mathrm{m} / \mathrm{z}=365.1\left([\mathrm{M}-\mathrm{H}]^{-}\right)$, HRMS for $\mathrm{C}_{17} \mathrm{H}_{21} \mathrm{~N}_{2} \mathrm{O}_{7}$ : calculated 365.1342, found 365.1349.

General procedure C. Synthesis of Compounds 5a-c, 13, 21, 41 and 44 (with 5a as an Example). To the suspension of $4(0.872 \mathrm{~g}, 2.38 \mathrm{mmol})$ and TBTU $(0.993 \mathrm{~g}, 3.09 \mathrm{mmol})$ in anhydrous DMF (48 mL), $N$-methylmorpholine $(1.42 \mathrm{~mL}, 12.99 \mathrm{mmol})$ was added. The reaction mixture was stirred at $\mathrm{rt}$ for $30 \mathrm{~min}$ upon which a clear solution formed. Glycine methyl ester hydrochloride $(0.328 \mathrm{~g}$, $2.62 \mathrm{mmol}$ ) was added and the mixture was stirred at $60{ }^{\circ} \mathrm{C}$ for $12 \mathrm{~h}$. The solvent was removed under reduced pressure and the residue was dissolved in ethyl acetate $(30 \mathrm{~mL})$ and $\mathrm{NaHCO}_{3}$ solution $(30 \mathrm{~mL})$. The organic phase was dried over $\mathrm{Na}_{2} \mathrm{SO}_{4}$, filtered and the solvent evaporated under reduced pressure. The residue was purified with column chromatography using ethyl acetate/petroleum ether (4/1) as an eluent to give $\mathbf{5 a}(0.770 \mathrm{~g})$ as a pale yellow solid.

tert-Butyl 4-(5-((2-methoxy-2-oxoethyl)carbamoyl)-2-nitrophenoxy)piperidine-1carboxylate (5a). Pale yellow solid; yield 74\% (0.770 g); mp 115-116 ${ }^{\circ} \mathrm{C}$; IR (ATR) = 3373, 2964, 2867, 1752, 1663, 1523, 1479, 1412, 1163, 1032, 960, 842, $747 \mathrm{~cm}^{-1} .{ }^{1} \mathrm{H}$ NMR (400 MHz, $\left.\mathrm{CDCl}_{3}\right): /=1.49\left(\mathrm{~s}, 9 \mathrm{H}, 3 \times \mathrm{CH}_{3}\right), 1.83-1.99(\mathrm{~m}, 4 \mathrm{H}, 4 \times(\mathrm{CH}) \mathrm{CH}-\mathrm{O}-\mathrm{Ar}), 3.52-3.62(\mathrm{~m}, 4 \mathrm{H}$, $4 \times \mathrm{C}$ HNBoc), $3.85\left(\mathrm{~s}, 3 \mathrm{H}, \mathrm{COOCH}_{3}\right), 4.27\left(\mathrm{~d}, 2 \mathrm{H},{ }^{3} \mathrm{~J}=5.0 \mathrm{~Hz}, \mathrm{NHC}_{2} \mathrm{COOCH}_{3}\right), 4.79-4.84(\mathrm{~m}$, $1 \mathrm{H}, \mathrm{C} \underline{\mathrm{H}}-\mathrm{O}-\mathrm{Ar}), 6.74\left(\mathrm{t}, 1 \mathrm{H},{ }^{3} \mathrm{~J}=5.0 \mathrm{~Hz}, \mathrm{NHCH}_{2} \mathrm{COOCH}_{3}\right), 7.35\left(\mathrm{dd}, 1 \mathrm{H},{ }^{3} \mathrm{~J}=8.4 \mathrm{~Hz},{ }^{4} \mathrm{~J}=1.6 \mathrm{~Hz}\right.$, Ar-H-4), 7.64 (d, 1H, $\left.{ }^{4} J=1.6 \mathrm{~Hz}, \mathrm{Ar}-\mathrm{H}-6\right), 7.87$ (d, 1H, $\left.{ }^{3} \mathrm{~J}=8.4 \mathrm{~Hz}, \mathrm{Ar}-\mathrm{H}-3\right) .{ }^{13} \mathrm{C}$ NMR (100 MHz, $\left.\mathrm{CDCl}_{3}\right) / 28.44\left(3 \times \underline{\mathrm{CH}}_{3}\right), 30.04,39.94,41.89,52.76,74.09,79.78,115.47,117.90,125.86$, $138.50,142.72,150.73,154.72,165.36,170.17\left(\mathrm{COOCH}_{3}\right) . \mathrm{MS}(\mathrm{ESI}) \mathrm{m} / \mathrm{z}=463.2([\mathrm{M}-\mathrm{H}]-)$, HRMS for $\mathrm{C}_{20} \mathrm{H}_{26} \mathrm{~N}_{3} \mathrm{O}_{8}$ : calculated 436.1730, found 436.1720.

General procedure D. Synthesis of Compounds 6a-c, 14, 22, 32, 38, 42 and 49 (with 6a as an Example). Compound 5a $(0.750 \mathrm{~g}, 1.71 \mathrm{mmol})$ was dissolved in $\mathrm{MeOH}(20 \mathrm{~mL})$ and the mixture was stirred for $30 \mathrm{~min}$ under argon atmosphere. $\mathrm{Pd} / \mathrm{C}(0.075 \mathrm{~g})$ was added and the reaction mixture was stirred under hydrogen atmosphere for $5 \mathrm{~h}$. The catalyst was filtered off and the solvent removed under reduced pressure to obtain $6 \mathbf{a}(0.686 \mathrm{~g})$ as light brown oil.

tert-Butyl 4-(2-amino-5-((2-methoxy-2-oxoethyl)carbamoyl)phenoxy)piperidine-1carboxylate (6a). Light brown oil; yield 98\% (0.686 g); IR (ATR) = 3350, 2962, 1750, 1681, $1611,1524,1506,1428,1365,1223,1164,1030,762 \mathrm{~cm}^{-1} .{ }^{1} \mathrm{H}$ NMR $\left(400 \mathrm{MHz}, \mathrm{CDCl}_{3}\right) /=1.49$ 
(s, 9H, $\left.3 \times \mathrm{CH}_{3}\right), 1.72-1.80(\mathrm{~m}, 2 \mathrm{H}, 2 \times(\mathrm{C} \underline{\mathrm{H}}) \mathrm{CH}-\mathrm{O}-\mathrm{Ar}), 1.96-2.04(\mathrm{~m}, 2 \mathrm{H}, 2 \times(\mathrm{C} \underline{\mathrm{H}}) \mathrm{CH}-\mathrm{O}-\mathrm{Ar}), 3.27-$ $3.34(\mathrm{~m}, 2 \mathrm{H}, 2 \times \mathrm{C} \underline{\mathrm{H} N B o c}), 3.72-3.80(\mathrm{~m}, 2 \mathrm{H}, 2 \times \mathrm{C} \underline{\mathrm{HNBoc}}), 3.82\left(\mathrm{~s}, 3 \mathrm{H}, \mathrm{COOCH}_{3}\right), 4.16(\mathrm{~s}, 2 \mathrm{H}$, $\left.\mathrm{NH}_{2}\right), 4.24\left(\mathrm{~d}, 2 \mathrm{H},{ }^{3} \mathrm{~J}=5.0 \mathrm{~Hz}, \mathrm{NHCH}_{2} \mathrm{COOCH}_{3}\right), 4.55-4.63$ (m, $\left.1 \mathrm{H}, \mathrm{CH}-\mathrm{O}-\mathrm{Ar}\right), 6.52\left(\mathrm{t}, 1 \mathrm{H},{ }^{3} \mathrm{~J}=\right.$ $\left.5.0 \mathrm{~Hz}, \mathrm{NHCH}_{2} \mathrm{COOCH}_{3}\right), 6.71\left(\mathrm{~d}, 1 \mathrm{H},{ }^{3} J=8.0 \mathrm{~Hz}, \mathrm{Ar}-\mathrm{H}-3\right), 7.22\left(\mathrm{dd}, 1 \mathrm{H},{ }^{3} J=8.0 \mathrm{~Hz},{ }^{4} \mathrm{~J}=1.8\right.$ $\mathrm{Hz}, \mathrm{Ar}-\mathrm{H}-4), 7.42\left(\mathrm{~d}, 1 \mathrm{H},{ }^{4} \mathrm{~J}=1.8 \mathrm{~Hz}, \mathrm{Ar}-\mathrm{H}-6\right) .{ }^{13} \mathrm{C}$ NMR $\left(100 \mathrm{MHz}\right.$, DMSO- $\left.d_{6}\right) /=28.05(3 \times$ $\left.\mathrm{CH}_{3}\right), 30.27,41.12,51.60,54.89,72.47,78.64,112.76,113.32,120.56,121.81,142.32,142.79$, $153.89,166.45,170.82\left(\underline{\mathrm{COOCH}}_{3}\right)$. MS (ESI) $\mathrm{m} / \mathrm{z}=408.2\left([\mathrm{M}+\mathrm{H}]^{+}\right)$, HRMS for $\mathrm{C}_{20} \mathrm{H}_{30} \mathrm{~N}_{3} \mathrm{O}_{6}$ : calculated 408.2127, found 408.2135.

General procedure E. Synthesis of Compounds 7a-d, 15, 23, 43a-b, 46a-b, 50, 56 and 60 (with 7 a as an Example). To a solution of 4,5-dibromo-1H-pyrrole-2-carboxylic acid (200 mg, 0.743 $\mathrm{mmol})$ in anhydrous dichloromethane $(5 \mathrm{~mL})$, oxalyl chloride $(0.317 \mathrm{~mL}, 3.70 \mathrm{mmol})$ was added dropwise and the solution stirred at $\mathrm{rt}$ for $15 \mathrm{~h}$ under argon atmosphere. The solvent was evaporated under reduced pressure, fresh anhydrous dichloromethane $(2 \mathrm{~mL}), 6 \mathbf{a}(0.251 \mathrm{~g}, 0.616 \mathrm{mmol})$ and pyridine $(2 \mathrm{~mL})$ were added and the reaction mixture stirred under argon atmosphere at $\mathrm{rt}$ for $15 \mathrm{~h}$. Solvent was removed under reduced pressure, the residue dissolved in ethyl acetate $(15 \mathrm{~mL})$ and washed with $\mathrm{HCl} 1 \mathrm{M}$ solution $(15 \mathrm{~mL})$ and brine $(2 \times 15 \mathrm{~mL})$. The organic phase was dried over $\mathrm{Na}_{2} \mathrm{SO}_{4}$, filtered and the solvent removed under reduced pressure. The solid was then washed with diethyl ether $(2 \times 5 \mathrm{~mL})$ to afford $7 \mathbf{a}(0.153 \mathrm{~g})$ as light brown solid.

tert-Butyl

4-(2-(4,5-dibromo-1H-pyrrole-2-carboxamido)-5-((2-methoxy-2oxoethyl)carbamoyl)phenoxy)piperidine-1-carboxylate (7a). Light brown solid; yield 38\% $(0.153 \mathrm{~g}) ; \mathrm{mp} 204-205^{\circ} \mathrm{C}$; IR (ATR) = 3402, 3357, 3296, 2955, 1724, 1693, 1642, 1656, 1513, $1414,1367,1316,1239,1169,1127,1050,758,651 \mathrm{~cm}^{-1} .{ }^{1} \mathrm{H}$ NMR $\left(400 \mathrm{MHz}\right.$, DMSO- $\left.d_{6}\right) /=$ $1.40\left(\mathrm{~s}, 9 \mathrm{H}, 3 \times \mathrm{CH}_{3}\right), 1.64-1.73(\mathrm{~m}, 2 \mathrm{H}, 2 \times(\mathrm{C} \underline{\mathrm{H}}) \mathrm{CH}-\mathrm{O}-\mathrm{Ar}), 1.86-1.95(\mathrm{~m}, 2 \mathrm{H}, 2 \times(\mathrm{C} \underline{\mathrm{H}}) \mathrm{CH}-\mathrm{O}-\mathrm{Ar})$, 3.18-3.29 (m, 2H, $2 \times$ CHNBoc), 3.60-3.66 (m, 5H, $2 \times$ CHNBoc, $\left.\mathrm{COOCH}_{3}\right), 4.02\left(\mathrm{~d}, 2 \mathrm{H},{ }^{3} J=5.8\right.$ $\left.\mathrm{Hz}, \mathrm{NHC}_{2} \mathrm{COOCH}_{3}\right), 4.65-4.70$ (m, 1H, C $\left.\underline{\mathrm{H}}-\mathrm{O}-\mathrm{Ar}\right), 7.18\left(\mathrm{~d}, 1 \mathrm{H},{ }^{4} \mathrm{~J}=2.5 \mathrm{~Hz}\right.$, Pyrrole-CH), 7.22 $\left(\mathrm{dd}, 1 \mathrm{H},{ }^{3} J=8.4 \mathrm{~Hz},{ }^{4} J=1.7 \mathrm{~Hz}, \mathrm{Ar}-\mathrm{H}-4\right), 7.59\left(\mathrm{~d}, 1 \mathrm{H},{ }^{4} J=1.7 \mathrm{~Hz}, \mathrm{Ar}-\mathrm{H}-6\right), 7.90\left(\mathrm{~d}, 1 \mathrm{H},{ }^{3} J=8.4\right.$ $\mathrm{Hz}, \mathrm{Ar}-\mathrm{H}-3), 8.92\left(\mathrm{t}, 1 \mathrm{H},{ }^{3} J=5.8 \mathrm{~Hz}, \mathrm{NHCH}_{2} \mathrm{COOCH}_{3}\right), 9.15$ (s, $\left.1 \mathrm{H}, \mathrm{NHAr}\right), 13.01\left(\mathrm{~d}, 1 \mathrm{H},{ }^{4} J=\right.$ $2.5 \mathrm{~Hz}$, Pyrrole-NH). ${ }^{13} \mathrm{C}$ NMR (100 MHz, DMSO- $\left.d_{6}\right) / 28.04\left(3 \times \underline{\mathrm{CH}}_{3}\right), 30.03,41.24,51.74$, 73.31, 78.71, 98.39, 106.33, 112.99, 113.90, 120.09, 123.27, 127.56, 130.17, 130.70, 148.08, $153.86,157.13,165.93,170.45$, one aliphatic signal is not seen. MS (ESI) $m / z=655.0\left([\mathrm{M}-\mathrm{H}]^{-}\right)$, HRMS for $\mathrm{C}_{25} \mathrm{H}_{29} \mathrm{Br}_{2} \mathrm{~N}_{4} \mathrm{O}_{7}$ : calculated 655.0400, found 655.0403; HPLC: Phenomenex Luna C18 
column $(5 \mu \mathrm{m}, 4.6 \times 250 \mathrm{~mm})$; mobile phase: $10-70 \%$ of acetonitrile in phosphate buffer $(\mathrm{pH}=$ 6.8 ) in $15 \mathrm{~min}, 70 \%$ acetonitrile to $25 \mathrm{~min}$; flow rate $1.0 \mathrm{~mL} / \mathrm{min}$; injection volume: $10 \mathrm{~L}$; $\mathrm{t}_{\mathrm{R}}$ : $21.273 \mathrm{~min}(96.8 \%$ at $280 \mathrm{~nm})$.

tert-Butyl 4-(2-(3,4-dichloro-5-methyl-1H-pyrrole-2-carboxamido)-5-((2-methoxy-2oxoethyl)carbamoyl)phenoxy)piperidine-1-carboxylate (7b). Synthesized according to General procedure E from 6a (397 mg, $0.975 \mathrm{mmol})$, with 3,4-dichloro-5-methyl-1H-pyrrole-2-carboxylic acid (0.228 g, $1.17 \mathrm{mmol})$ instead of 4,5-dibromo-1H-pyrrole-2-carboxylic acid as a reagent. During extraction a precipitate formed which was filtered off. The mother liquor was extracted and the filtered part of the compound was combined with the part after extraction. To the crude product diethyl ether $(15 \mathrm{~mL})$ was added, the obtained suspension was sonicated, filtered, washed with diethyl ether $(2 \times 5 \mathrm{~mL})$ and dried to afford $7 \mathbf{b}(0.200 \mathrm{~g})$ as white solid. Yield $31 \%(0.200 \mathrm{~g})$; $\mathrm{mp}$ 213-215 ${ }^{\circ} \mathrm{C}$; IR (ATR) = 3410, 3359, 3303, 2956, 2850, 1726, 1695, 1642, 1511, 1413, 1367 , 1238, 1209, 1170, 1125, 1050, 758, $651 \mathrm{~cm}^{-1} .{ }^{1} \mathrm{H}$ NMR (400 MHz, DMSO- $\left.d_{6}\right) /=1.42(\mathrm{~s}, 9 \mathrm{H}, 3 \times$

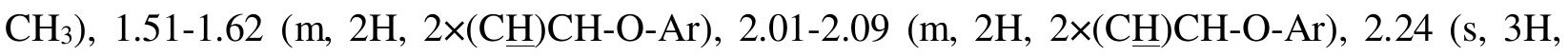

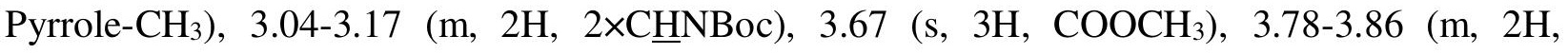
$2 \times \mathrm{C} \underline{\mathrm{HNBoc}}$ ), 4.03 (d, 2H, ${ }^{3} \mathrm{~J}=5.8 \mathrm{~Hz}, \mathrm{NHC}_{2} \mathrm{COOCH}_{3}$ ), 4.74-4.81 (m, 1H, C$\left.-\mathrm{H}-\mathrm{Ar}\right), 7.56$ (dd, $\left.1 \mathrm{H},{ }^{3} J=8.6 \mathrm{~Hz},{ }^{4} J=1.8 \mathrm{~Hz}, \mathrm{Ar}-\mathrm{H}-4\right), 7.65\left(\mathrm{~d}, 1 \mathrm{H},{ }^{4} \mathrm{~J}=1.8 \mathrm{~Hz}, \mathrm{Ar}-\mathrm{H}-6\right), 8.47$ (d, $1 \mathrm{H},{ }^{3} J=8.6 \mathrm{~Hz}$,

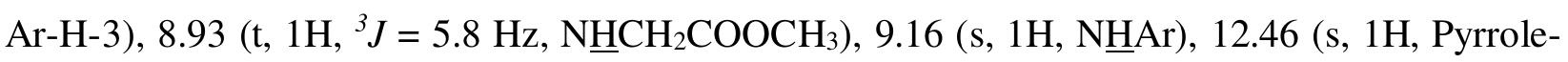
$\mathrm{NH}) .{ }^{13} \mathrm{C}$ NMR (100 MHz, DMSO-d $) /=10.75\left(\right.$ Pyrrole- $\left.\mathrm{CH}_{3}\right), 28.02\left(3 \times \underline{\mathrm{CH}}_{3}\right), 30.63,41.25$, $51.73,74.10,78.85,108.59$, 109.75, 111.83, 118.49, 118.69, 120.62, 128.53, 129.79, 131.21, 144.92, 153.93, 156.33, 165.84, 170.48, one aliphatic signal is not seen. MS (ESI) $\mathrm{m} / \mathrm{z}=581.1$ ([M-H] $\left.]^{-}\right), \mathrm{HRMS}$ for $\mathrm{C}_{26} \mathrm{H}_{31} \mathrm{Cl}_{2} \mathrm{~N}_{4} \mathrm{O}_{7}$ : calculated 581.1564, found 581.1570. HPLC: Phenomenex Luna C18 column $(5 \mu \mathrm{m}, 4.6 \times 250 \mathrm{~mm})$; mobile phase: $10-70 \%$ of acetonitrile in phosphate buffer $(\mathrm{pH}=6.8)$ in $15 \mathrm{~min}, 70 \%$ acetonitrile to $25 \mathrm{~min}$; flow rate $1.0 \mathrm{~mL} / \mathrm{min}$; injection volume: $10 \mathrm{~L}$; $\mathrm{t}_{\mathrm{R}}: 21.223 \mathrm{~min}(96.2 \%$ at $280 \mathrm{~nm})$.

\section{(S)-tert-Butyl 4-(2-(3,4-dichloro-5-methyl-1H-pyrrole-2-carboxamido)-5-((1-methoxy-1-} oxopropan-2-yl)carbamoyl)phenoxy)piperidine-1-carboxylate (7c). Synthesized according to General procedure E from $6 \mathbf{b}(179 \mathrm{mg}, 0.425 \mathrm{mmol})$, with 3,4-dichloro-5-methyl-1H-pyrrole-2carboxylic acid $(0.099 \mathrm{~g}, 0.51 \mathrm{mmol})$ instead of 4,5-dibromo- $1 H$-pyrrole-2-carboxylic acid as a reagent. During extraction a precipitate formed which was filtered off. The mother liquor was extracted and the filtered part of the compound was combined with the part after extraction. To the 
crude product diethyl ether $(15 \mathrm{~mL})$ was added, the obtained suspension was sonicated, filtered, washed with diethyl ether $(2 \times 5 \mathrm{~mL})$ and dried to afford $7 \mathrm{c}(0.150 \mathrm{~g})$ as light brown solid. Yield $59 \%$ (0.150 g); mp $181-185^{\circ} \mathrm{C} ;[.]_{\mathrm{D}}{ }^{25}+10.8$ (c 0.167, MeOH). IR (ATR) = 3373, 2935, 1739, 1682, 1643, 1659, 1596, 1510, 1418, 1239, 1163, 1134, 1032, 977, 868, $757 \mathrm{~cm}^{-1}$. ${ }^{1} \mathrm{H}$ NMR (400

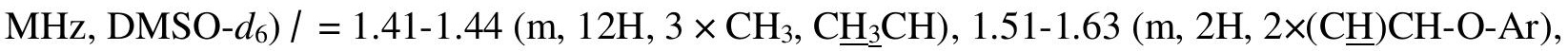
1.99-2.09 (m, 2H, 2×(C

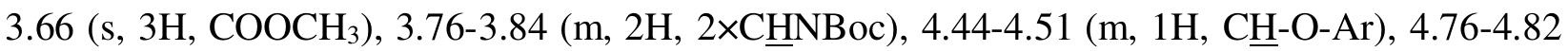
$(\mathrm{m}, 1 \mathrm{H}, \mathrm{NHCHCOOCH} 3), 7.59\left(\mathrm{dd}, 1 \mathrm{H},{ }^{3} \mathrm{~J}=8.6 \mathrm{~Hz},{ }^{4} \mathrm{~J}=1.7 \mathrm{~Hz}, \mathrm{Ar}-\mathrm{H}-4\right), 7.64\left(\mathrm{~d}, 1 \mathrm{H},{ }^{4} \mathrm{~J}=1.7\right.$ $\mathrm{Hz}, \mathrm{Ar}-\mathrm{H}-6), 8.46$ (d, 1H, $\left.{ }^{3} \mathrm{~J}=8.6 \mathrm{~Hz}, \mathrm{Ar}-\mathrm{H}-3\right), 8.75$ (d, 1H, $\left.{ }^{3} \mathrm{~J}=6.9 \mathrm{~Hz}, \mathrm{NHCHCOOCH}_{3}\right), 9.16$ (s, 1H, N $\underline{H A r}$ ), 12.45 (s, 1H, Pyrrole-NH). ${ }^{13} \mathrm{C}$ NMR (100 MHz, DMSO-d6) / = 10.76 (Pyrrole$\left.\mathrm{CH}_{3}\right), 16.76\left(\mathrm{CH}_{3} \mathrm{CH}\right), 28.01\left(3 \times \mathrm{CH}_{3}\right), 30.57,48.34,51.88\left(\mathrm{OCH}_{3}\right), 74.11,78.85,108.59,109.74$, 112.22 , 118.42, 118.69, 120.81, 128.60, 129.79, 131.27, 144.89, 153.95, 156.33, 165.46, 173.26, one aliphatic signal is not seen. MS (ESI) $m / z=595.2\left([\mathrm{M}-\mathrm{H}]^{-}\right)$, HRMS for $\mathrm{C}_{27} \mathrm{H}_{33} \mathrm{Cl}_{2} \mathrm{~N}_{4} \mathrm{O}_{7}$ : calculated 595.1721, found 595.1726. HPLC: Phenomenex Luna C18 column $(5 \mu \mathrm{m}, 4.6 \times 250$ $\mathrm{mm}$ ); mobile phase: 10-70\% of acetonitrile in phosphate buffer $(\mathrm{pH}=6.8)$ in $15 \mathrm{~min}, 70 \%$ acetonitrile to $25 \mathrm{~min}$; flow rate $1.0 \mathrm{~mL} / \mathrm{min}$; injection volume: $10 \mathrm{~L}$; $\mathrm{t}_{\mathrm{R}}: 22.793 \mathrm{~min}(97.9 \%$ at $220 \mathrm{~nm})$.

\section{(R)-tert-Butyl 4-(2-(3,4-dichloro-5-methyl-1H-pyrrole-2-carboxamido)-5-((1-methoxy-1-} oxopropan-2-yl)carbamoyl)phenoxy)piperidine-1-carboxylate (7d). Synthesized according to General procedure E from 6c (397 mg, 0.942 mmol), with 3,4-dichloro-5-methyl-1H-pyrrole-2carboxylic acid $(0.220 \mathrm{~g}, 1.13 \mathrm{mmol})$ instead of 4,5-dibromo- $1 \mathrm{H}$-pyrrole-2-carboxylic acid as a reagent. During extraction a precipitate formed which was filtered off. The mother liquor was extracted and the filtered part of the compound was combined with the part after extraction. To the crude product diethyl ether $(15 \mathrm{~mL})$ was added, the obtained suspension was sonicated, filtered, washed with diethyl ether $(2 \times 5 \mathrm{~mL})$ and dried to afford $7 \mathbf{d}(0.350 \mathrm{~g})$ as light brown solid. Yield $60 \%$ (0.350 g); mp 181-185 ${ }^{\circ} \mathrm{C}$; [. ] ${ }_{\mathrm{D}}^{25}-11.7$ (c 0.213, MeOH). IR (ATR) = 3369, 2974, 1741, 1683, 1643, 1595, 1510, 1347, 1240, 1032, 868, $758 \mathrm{~cm}^{-1} .{ }^{1} \mathrm{H}$ NMR $\left(400 \mathrm{MHz}, \mathrm{DMSO}-d_{6}\right) /=$

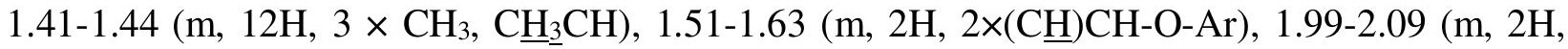
$2 \times(\mathrm{C} \underline{\mathrm{H}}) \mathrm{CH}-\mathrm{O}-\mathrm{Ar}), 2.24$ (s, 3H, Pyrrole- $\left.\mathrm{CH}_{3}\right), 3.06-3.19(\mathrm{~m}, 2 \mathrm{H}, 2 \times \mathrm{C} \underline{\mathrm{H} B o c}), 3.66$ (s, 3H,

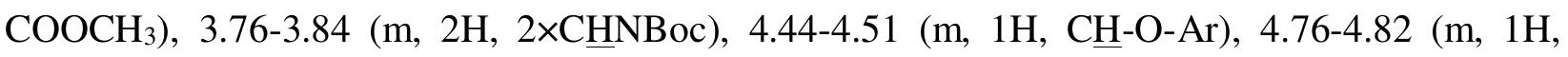
$\mathrm{NHC}_{\mathrm{HCOOCH}}$ ), $7.59\left(\mathrm{dd}, 1 \mathrm{H},{ }^{3} \mathrm{~J}=8.6 \mathrm{~Hz},{ }^{4} \mathrm{~J}=1.7 \mathrm{~Hz}, \mathrm{Ar}-\mathrm{H}-4\right), 7.64\left(\mathrm{~d}, 1 \mathrm{H},{ }^{4} \mathrm{~J}=1.7 \mathrm{~Hz}, \mathrm{Ar}-\mathrm{H}-\right.$ 
6), $8.46\left(\mathrm{~d}, 1 \mathrm{H},{ }^{3} \mathrm{~J}=8.6 \mathrm{~Hz}, \mathrm{Ar}-\mathrm{H}-3\right), 8.75\left(\mathrm{~d}, 1 \mathrm{H},{ }^{3} \mathrm{~J}=6.9 \mathrm{~Hz}, \mathrm{NHCHCOOCH}_{3}\right), 9.16(\mathrm{~s}, 1 \mathrm{H}$, N $\underline{H A r}$ ), 12.45 (s, 1H, Pyrrole-NH). ${ }^{13} \mathrm{C}$ NMR (100 MHz, DMSO- $\left.d_{6}\right) /=10.76\left(\right.$ Pyrrole- $\left.\mathrm{CH}_{3}\right)$, $16.76\left(\mathrm{CH}_{3}\right), 28.01\left(3 \times \mathrm{CH}_{3}\right), 30.57,48.34,51.88\left(\mathrm{OCH}_{3}\right), 74.11,78.85,108.59,109.74,112.22$, $118.42,118.69,120.81,128.60,129.79,131.27,144.89,153.95,156.33,165.46,173.26$, one aliphatic signal is not seen. MS (ESI) $\mathrm{m} / z=595.2\left([\mathrm{M}-\mathrm{H}]^{-}\right)$, $\mathrm{HRMS}$ for $\mathrm{C}_{27} \mathrm{H}_{33} \mathrm{Cl}_{2} \mathrm{~N}_{4} \mathrm{O}_{7}$ : calculated 595.1721, found 595.1726. HPLC: Phenomenex Luna C18 column (5 $\mu \mathrm{m}, 4.6 \times 250 \mathrm{~mm})$; mobile phase: $10-70 \%$ of acetonitrile in phosphate buffer $(\mathrm{pH}=6.8)$ in $15 \mathrm{~min}, 70 \%$ acetonitrile to $25 \mathrm{~min}$; flow rate $1.0 \mathrm{~mL} / \mathrm{min}$; injection volume: $10 \mathrm{~L} ; \mathrm{t}_{\mathrm{R}}: 22.800 \mathrm{~min}(96.7 \%$ at $220 \mathrm{~nm})$.

(S)-tert-Butyl 3-(2-(3,4-dichloro-5-methyl-1H-pyrrole-2-carboxamido)-5-((2-methoxy-2oxoethyl)carbamoyl)phenoxy)pyrrolidine-1-carboxylate (15). Synthesized according to General procedure E from 14 (543 mg, $1.38 \mathrm{mmol}$ ), with 3,4-dichloro-5-methyl-1H-pyrrole-2carboxylic acid $(0.320 \mathrm{~g}, 1.65 \mathrm{mmol})$ instead of 4,5-dibromo- $1 \mathrm{H}$-pyrrole-2-carboxylic acid as a reagent. During extraction a precipitate formed which was filtered off. The mother liquor was extracted and the filtered part of the compound was combined with the part obtained after extraction. To the crude product diethyl ether $(15 \mathrm{~mL})$ was added, the obtained suspension was sonicated, filtered, washed with diethyl ether $(2 \times 5 \mathrm{~mL})$ and dried to afford $15(0.440 \mathrm{~g})$ as light brown solid. Yield $61 \%(0.440 \mathrm{~g})$; $\mathrm{mp} 218-220{ }^{\circ} \mathrm{C}$; [. $]_{\mathrm{D}}^{25}+57.7(c 0.137, \mathrm{MeOH})$. IR (ATR) = 3369, 3233, 2972, 1750, 1688, 1645, 1598, 1516, 1494, 1411, 1364, 1256, 1177, 1118, 882, 757 $\mathrm{cm}^{-1} .{ }^{1} \mathrm{H}$ NMR $\left(400 \mathrm{MHz}\right.$, DMSO- $\left.d_{6}\right) /=1.43\left(\mathrm{~d}, 9 \mathrm{H},{ }^{3} \mathrm{~J}=6.6 \mathrm{~Hz}, 3 \times \mathrm{CH}_{3}\right), 2.08-2.20(\mathrm{~m}, 2 \mathrm{H}$, $2 \times \mathrm{CH}$ ), 2.23 (s, 3H, Pyrrole- $\mathrm{CH}_{3}$ ), 3.44-3.67 (m, 7H, $\left.4 \times \mathrm{CH}, \mathrm{COOCH}_{3}\right), 4.03\left(\mathrm{~d}, 2 \mathrm{H},{ }^{3} \mathrm{~J}=5.8 \mathrm{~Hz}\right.$,

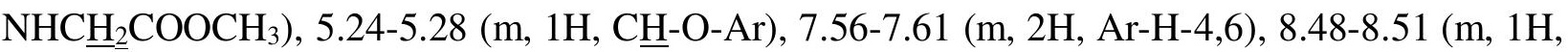
Ar-H-3), 8.98 (t, $\left.1 \mathrm{H},{ }^{3} J=5.8 \mathrm{~Hz}, \mathrm{NHCH}_{2} \mathrm{COOCH}_{3}\right), 9.17$ (d,1H, $\left.{ }^{3} J=7.0 \mathrm{HzNHAr}\right), 12.44$ (s, $1 \mathrm{H}$, Pyrrole-NH). ${ }^{13} \mathrm{C}$ NMR (100 MHz, DMSO- $\left.d_{6}\right) /=10.75\left(\right.$ Pyrrole- $\left.\mathrm{CH}_{3}\right), 28.09\left(3 \times \mathrm{CH}_{3}\right), 29.49$ and 30.40 (one split signal), 41.23, 43.55 and 43.71 (one split signal), 51.62 and 51.89 (one split signal), $51.74\left(\mathrm{COOCH}_{3}\right), 76.59$ and 77.53 (one split signal), 78.57 and 78.65 (one split signal), 108.64, 109.93, 110.58 and 110.74 (one split signal), 118.18, 118.58, 120.61 and 120.67 (one split signal), 128.27, 129.86, 130.95, 144.65, 153.34 and 153.52 (one split signal), 156.29, 165.78, 170.48. MS (ESI) $m / z=567.1\left([\mathrm{M}-\mathrm{H}]^{-}\right)$, HRMS for $\mathrm{C}_{25} \mathrm{H}_{29} \mathrm{Cl}_{2} \mathrm{~N}_{4} \mathrm{O}_{7}$ : calculated 567.1410, found 567.1413. HPLC: Phenomenex Luna C18 column $(5 \mu \mathrm{m}, 4.6 \times 250 \mathrm{~mm})$; mobile phase: $10-70 \%$ of acetonitrile in phosphate buffer $(\mathrm{pH}=6.8)$ in $15 \mathrm{~min}, 70 \%$ acetonitrile to $25 \mathrm{~min}$; flow rate 1.0 $\mathrm{mL} / \mathrm{min}$; injection volume: $10 \mathrm{~L}$; $\mathrm{t}_{\mathrm{R}}: 11.270 \mathrm{~min}(97.9 \%$ at $254 \mathrm{~nm})$. 
(R)-Methyl

2-(4-(3,4-dichloro-5-methyl-1H-pyrrole-2-carboxamido)-3-

isopropoxybenzamido)propanoate (23). Synthesized according to General procedure E from 22 (611 mg, $2.18 \mathrm{mmol}$ ), with 3,4-dichloro-5-methyl-1H-pyrrole-2-carboxylic acid (0.508 g, 2.62 mmol) instead of 4,5-dibromo-1H-pyrrole-2-carboxylic acid as a reagent. Instead of 2M solution of oxalyl chloride in dichloromethane, $98 \%$ oxalyl chloride $(0.905 \mathrm{~mL}, 10.48 \mathrm{mmol})$ was used. During extraction a precipitate formed which was filtered off. The mother liquor was extracted and the filtered part of the compound was combined with the part after extraction. To the crude product diethyl ether $(10 \mathrm{~mL})$ and a few drops of methanol were added, the obtained suspension was sonicated, filtered, washed with diethyl ether $(2 \times 5 \mathrm{~mL})$ and dried to afford 23 as off-white solid (762 mg). Yield 73\% (0.762 g); mp 220-222 ${ }^{\circ} \mathrm{C}$; [. ] ${ }^{25}-95.9$ (c 0.231, DMF). IR (ATR) = 3361, $3258,2992,1739,1632,1522,1495,1415,1309,1215,1106,1053,976,830,749 \mathrm{~cm}^{-1}$. ${ }^{1} \mathrm{H}$ NMR $\left(400 \mathrm{MHz}, \mathrm{DMSO}-d_{6}\right) /=1.36-1.38\left(\mathrm{~m}, 6 \mathrm{H}, \mathrm{CH}\left(\mathrm{C}_{3}\right)_{2}\right), 1.43\left(\mathrm{~d}, 3 \mathrm{H},{ }^{3} J=7.2 \mathrm{~Hz}, \mathrm{NHCHC}_{3}\right)$ ), 2.52 (s, 3H, Pyrrole- $\mathrm{CH}_{3}$ ), 3.66 (s, 3H, $\mathrm{COOCH}_{3}$ ), 4.49 (quint, $1 \mathrm{H},{ }^{3} \mathrm{~J}=7.2 \mathrm{~Hz}, \mathrm{NHC} \mathrm{HCH}_{3}$ ), 4.87 (spt, $\left.1 \mathrm{H},{ }^{3} J=6.0 \mathrm{~Hz}, \mathrm{C} \underline{\mathrm{H}}\left(\mathrm{CH}_{3}\right)_{2}\right), 7.57\left(\mathrm{dd}, 1 \mathrm{H},{ }^{3} J=8.4 \mathrm{~Hz},{ }^{4} J=1.6 \mathrm{~Hz}, \mathrm{Ar}-\mathrm{H}-6\right), 7.62\left(\mathrm{~d}, 1 \mathrm{H},{ }^{4} J\right.$ $=1.6 \mathrm{~Hz}, \mathrm{Ar}-\mathrm{H}-2), 8.47$ (d, 1H, $\left.{ }^{3} \mathrm{~J}=8.4 \mathrm{~Hz}, \mathrm{Ar}-\mathrm{H}-5\right), 8.74\left(\mathrm{~d}, 1 \mathrm{H},{ }^{3} \mathrm{~J}=6.8 \mathrm{~Hz}, \mathrm{NHCHCH}_{3}\right), 9.26$ (s, 1H, CONHAr), 12.46 (s, 1H, Pyrrole-NH). ${ }^{13} \mathrm{C}$ NMR (100 MHz, DMSO- $\left.d_{6}\right) /=10.75$ (Pyrrole$\left.\mathrm{CH}_{3}\right), 16.78\left(\mathrm{CH}_{3}\right), 21.77\left(\mathrm{CH}\left(\underline{\mathrm{CH}}_{3}\right)_{2}\right), 21.81\left(\mathrm{CH}\left(\underline{\mathrm{CH}}_{3}\right)_{2}\right), 48.31\left(\mathrm{CH}_{3}\right), 51.87(\mathrm{CH}), 71.31$ $\left(\underline{\mathrm{CH}}\left(\mathrm{CH}_{3}\right)_{2}\right), 108.60,109.72,111.68,117.96,118.64,120.54,128.40,129.78,131.23,145.16$, 156.21, $165.45(\mathrm{Ar}-\underline{\mathrm{CONH}}), 173.26\left(\mathrm{COOCH}_{3}\right) . \mathrm{MS}(\mathrm{ESI}) \mathrm{m} / z=454.1\left([\mathrm{M}-\mathrm{H}]^{-}\right)$. HRMS for $\mathrm{C}_{20} \mathrm{H}_{22} \mathrm{Cl}_{2} \mathrm{~N}_{3} \mathrm{O}_{5}$ : calculated 454.0937, found 454.0939. HPLC: Phenomenex Luna C18 column (5 $\mu \mathrm{m}, 4.6 \times 250 \mathrm{~mm})$; mobile phase: $10-70 \%$ of acetonitrile in phosphate buffer $(\mathrm{pH}=6.8)$ in 15 min, $70 \%$ acetonitrile to $25 \mathrm{~min}$; flow rate $1.0 \mathrm{~mL} / \mathrm{min}$; injection volume: $10 \mathrm{~L}$; $\mathrm{t}_{\mathrm{R}}: 11.270 \mathrm{~min}$ $(97.7 \%$ at $280 \mathrm{~nm})$.

\section{4,5-Dibromo- $N$-(4-((cyanomethyl)carbamoyl)phenyl)-1H-pyrrole-2-carboxamide}

(43a). Synthesized according to General procedure E from 42 (210 mg, $1.2 \mathrm{mmol})$. Brown solid. Yield $50 \%(0.312 \mathrm{~g}) ; \mathrm{mp}>300{ }^{\circ} \mathrm{C}$; IR $(\mathrm{ATR})=3252,1637,1594,1520,1409,1300,1248,1188,987$, 849, 752, $630 \mathrm{~cm}^{-1} .{ }^{1} \mathrm{H}$ NMR (400 MHz, DMSO-d $d_{6} /=4.30\left(\mathrm{~d}, 2 \mathrm{H},{ }^{3} \mathrm{~J}=5.4 \mathrm{~Hz}, \mathrm{CH}_{2}\right), 7.28(\mathrm{~d}$, $1 \mathrm{H},{ }^{4} \mathrm{~J}=2.8 \mathrm{~Hz}$, Pyrrole-CH), 7.82-7.88 (m, 4H, 4xAr-H), 9.11 (t, $\left.1 \mathrm{H},{ }^{3} J=5.4 \mathrm{~Hz}, \mathrm{NH}\right), 10.09$ (s, 1H, NHAr), 12.99 (d, $1 \mathrm{H},{ }^{4} \mathrm{~J}=2.8 \mathrm{~Hz}$, Pyrrole-NH). ${ }^{13} \mathrm{C}$ NMR $\left(100 \mathrm{MHz}, \mathrm{DMSO}-d_{6}\right) /=27.68$, 98.28, 106.51, 114.29, 117.76, 119.06, 127.35, 127.58, 128.27, 142.17, 157.44, 166.09. MS (ESI) $m / z=422.9\left([\mathrm{M}-\mathrm{H}]^{-}\right), \mathrm{HRMS}$ for $\mathrm{C}_{14} \mathrm{H}_{9} \mathrm{Br}_{2} \mathrm{~N}_{4} \mathrm{O}_{2}$ : calculated 422.9084, found 422.9092. HPLC: 
Phenomenex Luna C18 column $(5 \mu \mathrm{m}, 4.6 \times 250 \mathrm{~mm})$; mobile phase: 10-70\% of acetonitrile in phosphate buffer $(\mathrm{pH}=6.8)$ in $15 \mathrm{~min}, 70 \%$ acetonitrile to $25 \mathrm{~min}$; flow rate $1.0 \mathrm{~mL} / \mathrm{min}$; injection volume: $10 \mathrm{~L}$; $\mathrm{t}_{\mathrm{R}}: 13.940 \mathrm{~min}(95.4 \%$ at $220 \mathrm{~nm})$.

\section{3,4-Dichloro- $N$-(4-((cyanomethyl)carbamoyl)phenyl)-5-methyl-1H-pyrrole-2-}

carboxamide (43b). Synthesized according to General procedure E from 42 (250.5 mg, 1.43 mmol), with 3,4-dichloro-5-methyl-1H-pyrrole-2-carboxylic acid (0.333 g, $1.72 \mathrm{mmol})$ instead of 4,5-dibromo- $1 H$-pyrrole-2-carboxylic acid as a reagent. During extraction a precipitate formed which was filtered off. The mother liquor was extracted and the filtered part of the compound was combined with the part after extraction. The crude product was triturated with methanol and diethyl ether $(2: 1,8 \mathrm{~mL})$ and filtered off to afford $\mathbf{4 3 b}(0.380 \mathrm{~g})$ as light brown solid. Yield $79 \%(0.380$ g); $\operatorname{mp} 277-278^{\circ} \mathrm{C}$. IR (ATR) = 3385, 3243, 1641, 1594, 1527, 1470, 1311, 1254, 1186, 846, 588 $\mathrm{cm}^{-1} .{ }^{1} \mathrm{H}$ NMR (400 MHz, DMSO-d $) /=2.24$ (s, 3H, Pyrrole- $\left.\mathrm{CH}_{3}\right), 4.30\left(\mathrm{~d}, 2 \mathrm{H},{ }^{3} J=5.4 \mathrm{~Hz}, \mathrm{CH}_{2}\right)$, $7.77\left(\mathrm{~d}, 2 \mathrm{H},{ }^{3} \mathrm{~J}=8.7 \mathrm{~Hz}, 2 \times \mathrm{Ar}-\mathrm{H}\right), 7.87\left(\mathrm{~d}, 2 \mathrm{H},{ }^{3} J=8.7 \mathrm{~Hz}, 2 \times \mathrm{Ar}-\mathrm{H}\right), 9.11\left(\mathrm{t}, 1 \mathrm{H},{ }^{3} J=5.4 \mathrm{~Hz}\right.$, NH), 9.73 (s, 1H, NHAr), 12.25 (s, 1H, Pyrrole-NH). ${ }^{13} \mathrm{C}$ NMR (100 MHz, DMSO- $d_{6}$ ) / 10.80 (Pyrrole- $\left.\mathrm{CH}_{3}\right), 27.67\left(\mathrm{CH}_{2}\right), 108.62,111.82,117.76,119.07,119.36,127.49,128.31,128.39$, 141.88, 157.35, 166.04. MS (ESI) $m / z=349.0$ ([M-H] $]^{-}$), HRMS for $\mathrm{C}_{15} \mathrm{H}_{11} \mathrm{Cl}_{2} \mathrm{~N}_{4} \mathrm{O}_{2}$ : calculated 349.0251, found 349.0259. HPLC: Phenomenex Luna C18 column ( $5 \mu \mathrm{m}, 4.6 \times 250 \mathrm{~mm})$; mobile phase: $10-70 \%$ of acetonitrile in phosphate buffer $(\mathrm{pH}=6.8)$ in $15 \mathrm{~min}, 70 \%$ acetonitrile to $25 \mathrm{~min}$; flow rate $1.0 \mathrm{~mL} / \mathrm{min}$; injection volume: $10 \mathrm{~L}$; $\mathrm{t}_{\mathrm{R}}: 15.053 \mathrm{~min}(97.7 \%$ at $280 \mathrm{~nm})$.

\section{Diethyl 2-(4-(4,5-dibromo-1H-pyrrole-2-carboxamido)benzamido)malonate}

(46a).

Synthesized according to General procedure E from 45 (144 $\mathrm{mg}, 0.488 \mathrm{mmol})$. The crude product was triturated with diethyl ether $(5 \mathrm{~mL})$, filtered off and dried to afford $46(0.160 \mathrm{~g})$ as light brown solid. Yield 50\% (0.160 g); mp 191-193 ${ }^{\circ} \mathrm{C}$; IR (ATR) = 3398, 3303, 3229, 2987, 1730, 1643, 1514, 1412, 1328, 1216, 1170, 1027, 849, $627 \mathrm{~cm}^{-1} .{ }^{1} \mathrm{H}$ NMR (400 MHz, DMSO-d6) / = $1.23(\mathrm{t}$, $\left.6 \mathrm{H},{ }^{3} \mathrm{~J}=7.1 \mathrm{~Hz}, 2 \times \mathrm{COOCH}_{2} \mathrm{CH}_{3}\right), 4.15-4.27\left(\mathrm{~m}, 4 \mathrm{H}, 2 \times \mathrm{COOC}_{2} \mathrm{CH}_{3}\right), 5.30\left(\mathrm{~d}, 2 \mathrm{H},{ }^{3} \mathrm{~J}=7.6 \mathrm{~Hz}\right.$, NHC $\underline{H}), 7.29$ (d, 1H, ${ }^{4} J=2.8 \mathrm{~Hz}$, Pyrrole-CH), $7.83\left(\mathrm{~d}, 2 \mathrm{H},{ }^{3} \mathrm{~J}=8.9 \mathrm{~Hz}, 2 \times \mathrm{Ar}-\mathrm{H}\right), 7.92\left(\mathrm{~d}, 2 \mathrm{H},{ }^{3} J\right.$ $=8.9 \mathrm{~Hz}, 2 \times \mathrm{Ar}-\mathrm{H}), 9.21\left(\mathrm{~d}, 1 \mathrm{H},{ }^{3} \mathrm{~J}=7.6 \mathrm{~Hz}, \mathrm{NHCH}\right), 10.09$ (s, 1H, NHAr), 12.99 (d, $1 \mathrm{H},{ }^{4} \mathrm{~J}=2.8$ $\mathrm{Hz}$, Pyrrole-NH). ${ }^{13} \mathrm{C}$ NMR (100 MHz, DMSO- $\left.d_{6}\right) /=13.87,56.47,61.64,98.28,106.49,114.27$, 118.97, 127.39, 127.61, 128.57, 142.12, 157.45, 165.83, 166.64. MS (ESI) $m / z=542.0\left([\mathrm{M}-\mathrm{H}]^{-}\right)$, HRMS for $\mathrm{C}_{19} \mathrm{H}_{18} \mathrm{Br}_{2} \mathrm{~N}_{3} \mathrm{O}_{6}$ : calculated 541.9557, found 541.9562. HPLC: Phenomenex Luna C18 column $(5 \mu \mathrm{m}, 4.6 \times 250 \mathrm{~mm})$; mobile phase: $10-70 \%$ of acetonitrile in phosphate buffer $(\mathrm{pH}=$ 
6.8) in $15 \mathrm{~min}, 70 \%$ acetonitrile to $25 \mathrm{~min}$; flow rate $1.0 \mathrm{~mL} / \mathrm{min}$; injection volume: $10 \mathrm{~L} ; \mathrm{t}_{\mathrm{R}}$ : $16.583 \min (98.2 \%$ at $220 \mathrm{~nm})$.

\section{Diethyl 2-(4-(3,4-dichloro-5-methyl-1H-pyrrole-2-carboxamido)benzamido)malonate} (46b). Synthesized according to General procedure E from 45 (591 mg, $2.01 \mathrm{mmol})$, with 3,4dichloro-5-methyl-1H-pyrrole-2-carboxylic acid ( $0.468 \mathrm{~g}, 2.41 \mathrm{mmol})$ instead of 4,5-dibromo- $1 \mathrm{H}$ pyrrole-2-carboxylic acid as a reagent. During extraction a precipitate formed which was filtered off. The mother liquor was extracted and the filtered part of the compound was combined with the part after extraction. The crude product was triturated with methanol and diethyl ether $(2: 1,8 \mathrm{~mL})$ and filtered off to afford $46 \mathrm{~b}(0.265 \mathrm{~g})$ as light brown solid. Yield 27\% (0.265 g); mp 173-175 ${ }^{\circ} \mathrm{C}$; IR $($ ATR $)=3391,3252,2986,1754,1643,1594,1520,1475,1344,1233,1177,1024,849,736$, $564 \mathrm{~cm}^{-1} .{ }^{1} \mathrm{H}$ NMR $\left(400 \mathrm{MHz}, \mathrm{DMSO}-d_{6}\right) /=1.24\left(\mathrm{t}, 6 \mathrm{H},{ }^{3} \mathrm{~J}=7.1 \mathrm{~Hz}, 2 \times \mathrm{COOCH}_{2} \mathrm{C}_{2}\right), 2.25(\mathrm{~s}$, $3 \mathrm{H}$, Pyrrole- $\mathrm{CH}_{3}$ ), 4.15-4.27 (m, 4H, $\left.2 \times \mathrm{COOC}_{2} \mathrm{CH}_{3}\right), 5.30$ (d, $\left.2 \mathrm{H},{ }^{3} \mathrm{~J}=7.5 \mathrm{~Hz}, \mathrm{NHC} \underline{\mathrm{H}}\right), 7.77$ (d, $\left.2 \mathrm{H},{ }^{3} \mathrm{~J}=8.6 \mathrm{~Hz}, 2 \times \mathrm{Ar}-\mathrm{H}\right), 7.92\left(\mathrm{~d}, 2 \mathrm{H},{ }^{3} \mathrm{~J}=8.6 \mathrm{~Hz}, 2 \times \mathrm{Ar}-\mathrm{H}\right), 9.22\left(\mathrm{~d}, 1 \mathrm{H},{ }^{3} \mathrm{~J}=7.5 \mathrm{~Hz}, \mathrm{NHCH}\right)$, 9.71 (s, 1H, NHAr), 12.24 (s, 1H, Pyrrole-NH). ${ }^{13} \mathrm{C}$ NMR (100 MHz, DMSO- $d_{6}$ ) / 10.81, 13.87, $56.47,61.65,108.61,111.78,118.99,119.39,127.54,128.39$, 128.62, 141.83, 157.36, 165.80, 166.64. MS (ESI) $\mathrm{m} / z=468.1\left([\mathrm{M}-\mathrm{H}]^{-}\right)$, HRMS for $\mathrm{C}_{20} \mathrm{H}_{20} \mathrm{Cl}_{2} \mathrm{~N}_{3} \mathrm{O}_{6}$ : calculated 468.0725 , found 468.0725. HPLC: Phenomenex Luna C18 column $(5 \mu \mathrm{m}, 4.6 \times 250 \mathrm{~mm})$; mobile phase: $10-70 \%$ of acetonitrile in phosphate buffer $(\mathrm{pH}=6.8)$ in $15 \mathrm{~min}, 70 \%$ acetonitrile to $25 \mathrm{~min}$; flow rate 1.0 $\mathrm{mL} / \mathrm{min}$; injection volume: $10 \mathrm{~L}$; $\mathrm{t}_{\mathrm{R}}: 17.710 \mathrm{~min}(96.2 \%$ at $280 \mathrm{~nm})$.

\section{3,4-Dichloro-5-methyl- $N$-(4-(5-oxo-4,5-dihydro-1H-tetrazol-1-yl)phenyl)-1H-pyrrole-2-} carboxamide (50). Synthesized according to General procedure E from 49 (356 mg, $2.01 \mathrm{mmol}$ ), with 3,4-dichloro-5-methyl-1H-pyrrole-2-carboxylic acid $(0.468 \mathrm{~g}, 2.41 \mathrm{mmol})$ instead of 4,5dibromo-1 $H$-pyrrole-2-carboxylic acid as a reagent. The mixture was cooled on ice bath and the precipitate filtered off. The crude product was purified with flash column chromatography using dichloromethane/methanol (10/1) as an eluent to afford $\mathbf{5 0}(0.040 \mathrm{~g})$ as pink solid. Yield 10\% $(0.040 \mathrm{~g}) ; \mathrm{mp}>300{ }^{\circ} \mathrm{C}$; IR (ATR) = 3387, 3233, 1743, 1641, 1542, 1514, 1425, 1249, 1097, $1042,832,740 \mathrm{~cm}^{-1} .{ }^{1} \mathrm{H}$ NMR (400 MHz, DMSO- $\left.d_{6}\right) /=2.25$ (s, 3H, Pyrrole- $\left.\mathrm{CH}_{3}\right), 7.78(\mathrm{~d}, 2 \mathrm{H}$, ${ }^{3} J=8.7 \mathrm{~Hz}, 2 \times \mathrm{Ar}-\mathrm{H}$ ), $8.36\left(\mathrm{~d}, 2 \mathrm{H},{ }^{3} J=8.7 \mathrm{~Hz}, 2 \times \mathrm{Ar}-\mathrm{H}\right), 9.79$ (s, 1H, NHAr), 12.56 (br s, $1 \mathrm{H}$, Pyrrole- $\left.\mathrm{CH}_{3}\right)$, signal for 5-oxotetrazole NH is not seen. ${ }^{13} \mathrm{C}$ NMR $\left(100 \mathrm{MHz}\right.$, DMSO- $\left.d_{6}\right) /=10.75$ 
(Pyrrole- $\left.\mathrm{CH}_{3}\right), 108.63,112.51,118.90,119.02,120.16,127.62,131.98,136.23,156.95,159.33$. MS (ESI) $m / z=351.0\left([\mathrm{M}-\mathrm{H}]^{-}\right.$), HRMS for $\mathrm{C}_{13} \mathrm{H}_{9} \mathrm{Cl}_{2} \mathrm{~N}_{6} \mathrm{O}_{2}$ : calculated 351.0172, found 351.0158. HPLC: Phenomenex Luna C18 column $(5 \mu \mathrm{m}, 4.6 \times 250 \mathrm{~mm})$; mobile phase: $10-70 \%$ of acetonitrile in phosphate buffer $(\mathrm{pH}=6.8)$ in $15 \mathrm{~min}, 70 \%$ acetonitrile to $25 \mathrm{~min}$; flow rate 1.0 $\mathrm{mL} / \mathrm{min}$; injection volume: $10 \mathrm{~L}$; $\mathrm{t}_{\mathrm{R}}: 10.710 \mathrm{~min}(97.2 \%$ at $280 \mathrm{~nm})$.

Ethyl 7-(3,4-dichloro-5-methyl-1H-pyrrole-2-carboxamido)-1-ethyl-4-oxo-1,4dihydroquinoline-3-carboxylate (56). Synthesized according to General procedure E from $\mathbf{5 5}$ (349 mg, $1.34 \mathrm{mmol}$ ), with 3,4-dichloro-5-methyl-1H-pyrrole-2-carboxylic acid (0.312 g, 1.61 mmol) instead of 4,5-dibromo- $1 H$-pyrrole-2-carboxylic acid as a reagent. During extraction a precipitate formed which was filtered off. The solid was recrystallized twice from THF to afford $56(0.280 \mathrm{~g})$ as yellow solid. Yield $42 \%(0.280 \mathrm{~g}) ; \mathrm{mp} 277-280^{\circ} \mathrm{C}$. IR (ATR) $=3320,3110,2983$, $2886,1697,1671,1618,1565,1458,1301,1260,1096,1033,1016,800,730,595 \mathrm{~cm}^{-1} .{ }^{1} \mathrm{H}$ NMR $\left(400 \mathrm{MHz}, \mathrm{DMSO}-d_{6}\right) /=1.29\left(\mathrm{t}, 3 \mathrm{H},{ }^{3} J=7.1 \mathrm{~Hz}, \mathrm{COOCH}_{2} \underline{\mathrm{C}}_{3}\right), 1.44\left(\mathrm{t}, 3 \mathrm{H},{ }^{3} J=7.1 \mathrm{~Hz}\right.$, $\mathrm{NCH}_{2} \mathrm{CH}_{3}$ ), 2.25 (s, 3H, Pyrrole- $\left.\mathrm{CH}_{3}\right), 4.23$ (q, $\left.2 \mathrm{H},{ }^{3} \mathrm{~J}=7.1 \mathrm{~Hz}, \mathrm{COOC}_{2} \mathrm{CH}_{3}\right), 4.34$ (q, $2 \mathrm{H},{ }^{3} \mathrm{~J}=$ $\left.7.1 \mathrm{~Hz}, \mathrm{NC}_{2} \mathrm{CH}_{3}\right), 7.65$ (dd, $1 \mathrm{H},{ }^{3} J=8.8 \mathrm{~Hz},{ }^{4} J=1.7 \mathrm{~Hz}$, quinoline-H-6), $8.21\left(\mathrm{~d}, 1 \mathrm{H},{ }^{3} J=8.8\right.$ $\mathrm{Hz}$, quinoline-H-5), $8.26\left(\mathrm{~d}, 1 \mathrm{H},{ }^{4} \mathrm{~J}=1.7 \mathrm{~Hz}\right.$, quinoline-H-8), 8.69 (s, $\left.1 \mathrm{H}, \mathrm{CHNCH}_{2} \mathrm{CH}_{3}\right), 9.94$ (s, 1H, NHAr), 12.32 (br s, $1 \mathrm{H}$, Pyrrole-NH). ${ }^{13} \mathrm{C}$ NMR (100 MHz, DMSO- $d_{6}$ ) / 10.82 (Pyrrole- $\mathrm{CH}_{3}$ ), $14.03,14.31,48.13,59.64,105.97,108.78,110.04,112.09$, 117.11, 119.17, 124.02, 127.37, 128.71, 139.24, 142.48, 149.15, 157.66, 164.65, 172.27. MS (ESI) $\mathrm{m} / \mathrm{z}=434.1\left([\mathrm{M}-\mathrm{H}]^{-}\right)$, HRMS for $\mathrm{C}_{20} \mathrm{H}_{18} \mathrm{Cl}_{2} \mathrm{~N}_{3} \mathrm{O}_{4}$ : calculated 434.0670, found 434.0674. HPLC: Phenomenex Luna C18 column $(5 \mu \mathrm{m}, 4.6 \times 250 \mathrm{~mm})$; mobile phase: $10-70 \%$ of acetonitrile in phosphate buffer $(\mathrm{pH}=6.8)$ in 15 $\mathrm{min}, 70 \%$ acetonitrile to $25 \mathrm{~min}$; flow rate $1.0 \mathrm{~mL} / \mathrm{min}$; injection volume: $10 \mathrm{~L}$; $\mathrm{t}_{\mathrm{R}}: 15.677 \mathrm{~min}$ $(98.7 \%$ at $220 \mathrm{~nm})$.

Ethyl 5-(3,4-dichloro-5-methyl-1H-pyrrole-2-carboxamido)-1H-indole-2-carboxylate (60). Synthesized according to General procedure E from 59 (472 mg, $1.97 \mathrm{mmol}$ ), with 3,4-dichloro-5methyl-1 $H$-pyrrole-2-carboxylic acid $(0.458 \mathrm{~g}, 2.36 \mathrm{mmol})$ instead of 4,5-dibromo-1 $H$-pyrrole-2carboxylic acid as a reagent. After the addition of pyridine the reaction mixture was stirred for 12 h. A green-brown precipitate formed which was filtered off. the crude product was triturated with ethanol and diethyl ether $(2: 1,8 \mathrm{~mL})$ to afford $60(0.675 \mathrm{~g})$ as brown solid. Yield $79 \%(0.675 \mathrm{~g})$; mp 264-267 ${ }^{\circ} \mathrm{C}$; IR (ATR) $=3404,3288,3239,1686,1642,1530,1488,1418,1255,1202,1155$, 1090, 1023, 806, $767 \mathrm{~cm}^{-1} .{ }^{1} \mathrm{H}$ NMR $\left(400 \mathrm{MHz}\right.$, DMSO- $\left.d_{6}\right): /=1.35\left(\mathrm{t}, 3 \mathrm{H},{ }^{3} \mathrm{~J}=7.1 \mathrm{~Hz}\right.$, 
$\mathrm{COOCH}_{2} \underline{\mathrm{C}}_{3}$ ), 2.24 (s, 3H, Pyrrole- $\mathrm{CH}_{3}$ ), 4.35 (q, $2 \mathrm{H},{ }^{3} \mathrm{~J}=7.1 \mathrm{~Hz}, \mathrm{COOC} \underline{H}_{2} \mathrm{CH}_{3}$ ), 7.14-7.15 (m, 1H, Ar-H), 7.41-7.48 (m, 2H, 2×Ar-H), 8.03-8.06 (m, 1H, Ar-H), 9.34 (s, 1H, NHAr), 11.88 (s, 1H, Pyrrole-NH/indole-NH), 12.15 (s, 1H, Pyrrole-NH/indole-NH). ${ }^{13} \mathrm{C}$ NMR (100 MHz, DMSO$\left.d_{6}\right)$ / $10.75($ Pyrrole-CH 3$), 14.29\left(\mathrm{COOCH}_{2} \underline{\mathrm{CH}}_{3}\right), 60.41\left(\mathrm{COOCH}_{2} \mathrm{CH}_{3}\right), 107.65,108.24,110.71$,

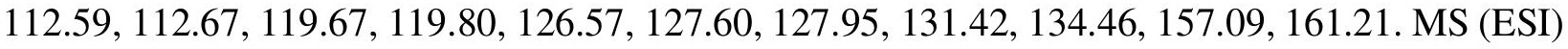
$m / z=378.0\left([\mathrm{M}-\mathrm{H}]^{-}\right), \mathrm{HRMS}$ for $\mathrm{C}_{17} \mathrm{H}_{14} \mathrm{Cl}_{2} \mathrm{~N}_{3} \mathrm{O}_{3}$ : calculated 378.0422, found 378.0429 HPLC: Phenomenex Luna C18 column $(5 \mu \mathrm{m}, 4.6 \times 250 \mathrm{~mm})$; mobile phase: $10-70 \%$ of acetonitrile in phosphate buffer $(\mathrm{pH}=6.8$ ) in $15 \mathrm{~min}, 70 \%$ acetonitrile to $25 \mathrm{~min}$; flow rate $1.0 \mathrm{~mL} / \mathrm{min}$; injection volume: $10 \mathrm{~L}$; $\mathrm{t}_{\mathrm{R}}: 18.893 \mathrm{~min}(98.7 \%$ at $280 \mathrm{~nm})$.

General procedure F. Synthesis of Compounds $8 a-d, 16$ and 34 (with $8 b$ as an Example). To a solution of compound $\mathbf{8 b}(0.050 \mathrm{~g}, 0.086 \mathrm{mmol})$ in a mixture of methanol (3 $\mathrm{mL})$ and THF (3 $\mathrm{mL}) 1 \mathrm{M} \mathrm{NaOH}(0.344 \mathrm{~mL}, 0.344 \mathrm{mmol})$ was added. The mixture was stirred at $\mathrm{rt}$ for $15 \mathrm{~h}$. The solvent was removed under reduced pressure, EtOAc $(10 \mathrm{~mL})$ and $1 \mathrm{M} \mathrm{HCl}(10 \mathrm{~mL})$ were added to the residue. The organic phase was washed with brine $(2 \times 10 \mathrm{~mL})$, dried over $\mathrm{Na}_{2} \mathrm{SO}_{4}$, filtered and the solvent removed under reduced pressure to afford $\mathbf{8 b}(0.038 \mathrm{~g})$ as white solid.

tert-Butyl 4-(2-(3,4-dichloro-5-methyl-1H-pyrrole-2-carboxamido)-5-((2-methoxy-2oxoethyl)carbamoyl)phenoxy)piperidine-1-carboxylate (8b). White solid; yield $77 \%$ (0.038 g); $\operatorname{mp} 223-225^{\circ} \mathrm{C}$; IR (ATR) = 3355, 3260, 2966, 2910, 1733, 1667, 1634, 1522, 1427, 1326, 1256, 1134, 1047, 838, 815, $765 \mathrm{~cm}^{-1} .{ }^{1} \mathrm{H}$ NMR (400 MHz, DMSO-d $)$ : / = 1.42 (s, 9H, $\left.3 \times \mathrm{CH}_{3}\right), 1.51$ -

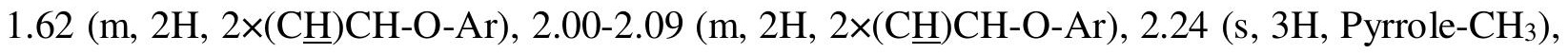

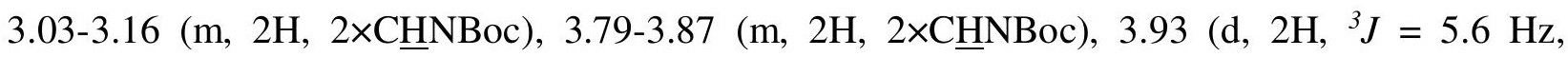

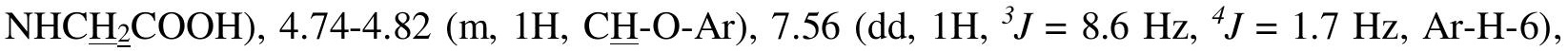
$7.65\left(\mathrm{~d}, 1 \mathrm{H},{ }^{4} \mathrm{~J}=1.7 \mathrm{~Hz}, \mathrm{Ar}-\mathrm{H}-2\right), 8.46\left(\mathrm{~d}, 1 \mathrm{H},{ }^{3} \mathrm{~J}=8.6 \mathrm{~Hz}, \mathrm{Ar}-\mathrm{H}-5\right), 8.82\left(\mathrm{t}, 1 \mathrm{H},{ }^{3} J=5.6 \mathrm{~Hz}\right.$, $\mathrm{NHCH}_{2} \mathrm{COOCH}_{3}$ ), 9.16 (s, 1H, NㅌA), 12.46 (s, 1H, Pyrrole-NH), 12.53 (br s, $\left.1 \mathrm{H}, \mathrm{COOH}\right) .{ }^{13} \mathrm{C}$ NMR (100 MHz, DMSO-d6) / $10.74\left(\right.$ Pyrrole- $\left.\mathrm{CH}_{3}\right), 28.01$ (3 $\left.\times \underline{\mathrm{CH}}_{3}\right), 30.63,41.23,74.11,78.89$, 108.59, 109.74, 111.83, 118.49, 118.69, 120.59, 128.79, 129.80, 131.11, 144.90, 153.96, 156.33, 165.74, 171.42, two aliphatic signal are not seen. MS (ESI) $m / z=567.1\left([\mathrm{M}-\mathrm{H}]^{-}\right)$, HRMS for $\mathrm{C}_{25} \mathrm{H}_{29} \mathrm{Cl}_{2} \mathrm{~N}_{4} \mathrm{O}_{7}$ : calculated 567.1421, found 567.1413; HPLC: Phenomenex Luna C18 column (5 $\mu \mathrm{m}, 4.6 \times 250 \mathrm{~mm})$; mobile phase: $10-70 \%$ of acetonitrile in phosphate buffer $(\mathrm{pH}=6.8)$ in 20 $\min , 70 \%$ acetonitrile to $25 \mathrm{~min}$; flow rate $1.0 \mathrm{~mL} / \mathrm{min}$; injection volume: $10 \mathrm{~L}$; $\mathrm{t}_{\mathrm{R}}: 16.333 \mathrm{~min}$ $(99.2 \%$ at $254 \mathrm{~nm})$. 
General procedure G. Synthesis of Compounds $9 a-b$ and 17 (with 9 a as an Example). Compound 8a $(0.020 \mathrm{~g}, 0.031 \mathrm{mmol})$ was dissolved in $\mathrm{HCl} 1 \mathrm{M}$ solution in acetic acid $(4 \mathrm{~mL})$ and in $1 \mathrm{~mL}$ of DMF. The mixture was stirred for $8 \mathrm{~h}$. After the completion of the reaction the solvent was removed under reduced pressure and the solid was washed with diethyl ether $(2 \times 5 \mathrm{~mL})$ to obtain $9 \mathbf{a}(0.014$ g) as brown solid.

\section{4-(5-((Carboxymethyl)carbamoyl)-2-(4,5-dibromo-1H-pyrrole-2-}

carboxamido)phenoxy)piperidin-1-ium chloride (9a). Brown solid; yield $78 \%$ (0.014 g); mp $>300{ }^{\circ} \mathrm{C}$; IR $(\mathrm{ATR})=3427,3128,2962,1731,1667,1637,1519,1391,1277,1199,1181,1023$,

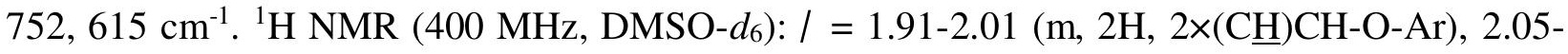
$2.15(\mathrm{~m}, 2 \mathrm{H}, 2 \times(\mathrm{C} \underline{\mathrm{H}}) \mathrm{CH}-\mathrm{O}-\mathrm{Ar}), 3.06-3.15\left(\mathrm{~m}, 2 \mathrm{H}, 2 \times \mathrm{CHNH}_{2}{ }^{+}\right), 3.23-3.31\left(\mathrm{~m}, 2 \mathrm{H}, 2 \times \mathrm{CHNH}_{2}{ }^{+}\right.$, overlapped with the signal for water), $3.93\left(\mathrm{~d}, 2 \mathrm{H},{ }^{3} \mathrm{~J}=5.4 \mathrm{~Hz}, \mathrm{NHCH}_{2} \mathrm{COOCH}_{3}\right), 4.75-4.82(\mathrm{~m}$, 1H, C$-\mathrm{H}-\mathrm{Ar}), 7.18$ (d, 1H, ${ }^{4} \mathrm{~J}=2.5 \mathrm{~Hz}$, Pyrrole-CH), 7.54 (d, 1H, $\left.{ }^{3} \mathrm{~J}=8.3 \mathrm{~Hz}, \mathrm{Ar}-\mathrm{H}-4\right), 7.61$ (s, $1 \mathrm{H}, \mathrm{Ar}-\mathrm{H}-6), 7.85$ (d, $\left.1 \mathrm{H},{ }^{3} \mathrm{~J}=8.3 \mathrm{~Hz}, \mathrm{Ar}-\mathrm{H}-3\right), 8.65$ (br s, $1 \mathrm{H}, \mathrm{Ha}$ from $\mathrm{NH}_{2}{ }^{+}$), 8.81 (br s, $1 \mathrm{H}, \mathrm{Hb}$ from $\mathrm{NH}_{2}{ }^{+}$), 8.89 (t, $\left.1 \mathrm{H},{ }^{3} \mathrm{~J}=5.4 \mathrm{~Hz}, \mathrm{NHCH}_{2} \mathrm{COOCH}_{3}\right), 9.38$ (s, 1H, NHAr), 12.61 (br s, 1H, $\mathrm{COOH}), 13.07$ (s, 1H, Pyrrole-NH). ${ }^{13} \mathrm{C}$ NMR (100 MHz, DMSO-d6): / = 26.85, 41.22, 69.92, $98.39,112.65,112.68,114.17,120.16,124.10,127.63,130.22$, 130.76, 148.31, 157.17, 165.70, 171.33, one aliphatic signal is not seen. MS (ESI) $m / z=541.0\left([\mathrm{M}-\mathrm{H}]^{-}\right)$, HRMS for $\mathrm{C}_{19} \mathrm{H}_{19} \mathrm{Br}_{2} \mathrm{~N}_{4} \mathrm{O}_{5}$ : calculated 540.9717, found 540.9722. HPLC: Phenomenex Luna C18 column $(5 \mu \mathrm{m}, 4.6 \times 250$ $\mathrm{mm}$ ); mobile phase: $10-70 \%$ of acetonitrile in phosphate buffer $(\mathrm{pH}=6.8)$ in $20 \mathrm{~min}, 70 \%$ acetonitrile to $25 \mathrm{~min}$; flow rate $1.0 \mathrm{~mL} / \mathrm{min}$; injection volume: $10 \mathrm{~L}$; $\mathrm{t}_{\mathrm{R}}: 10.250 \mathrm{~min}(95.3 \%$ at $220 \mathrm{~nm})$.

General procedure H. Synthesis of Compounds $9 c-d, 10 a-b$ and 18 (with $9 c$ as an Example).

Compound 8c $(0.050 \mathrm{~g}, 0.086 \mathrm{mmol})$ was dissolved in $\mathrm{HCl} 4 \mathrm{M}$ solution in dioxane $(4 \mathrm{~mL})$. The mixture was stirred for $4 \mathrm{~h}$. After the completion of the reaction the solvent removed under reduced pressure and the solid was washed with diethyl ether $(2 \times 5 \mathrm{~mL})$ to obtain $9 \mathrm{c}(0.018 \mathrm{~g})$ as brown solid.

(S)-4-(5-((1-Carboxyethyl)carbamoyl)-2-(3,4-dichloro-5-methyl-1H-pyrrole-2-

carboxamido)phenoxy)piperidin-1-ium chloride (9c). Brown solid; yield 40\% (0.018 g); mp $>300{ }^{\circ} \mathrm{C}$. [. $]_{\mathrm{D}}{ }^{25}+7.5(c 0.200, \mathrm{MeOH}) . \mathrm{IR}(\mathrm{ATR})=3363,3252,2945,2808,2723,1721,1647$, 1593, 1514, 1260, 1207, 1031, 991, 863, 759, $609 \mathrm{~cm}^{-1} .{ }^{1} \mathrm{H}$ NMR (400 MHz, DMSO- $\left.d_{6}\right) /=1.41$ $\left(\mathrm{d}, 3 \mathrm{H},{ }^{3} \mathrm{~J}=7.2 \mathrm{~Hz}, \mathrm{CH}_{3}\right), 1.85-1.96(\mathrm{~m}, 2 \mathrm{H}, 2 \times(\mathrm{C} \underline{\mathrm{H}}) \mathrm{CH}-\mathrm{O}-\mathrm{Ar}), 2.16-2.24(\mathrm{~m}, 5 \mathrm{H}, 2 \times(\mathrm{C} \underline{\mathrm{H}}) \mathrm{CH}-\mathrm{O}-$ 
Ar, Pyrrole- $\left.\mathrm{CH}_{3}\right), 3.04-3.16\left(\mathrm{~m}, 2 \mathrm{H}, 2 \times \mathrm{CHNH}_{2}^{+}\right), 3.76-3.85\left(\mathrm{~m}, 2 \mathrm{H}, 2 \times \mathrm{CHNH}_{2}{ }^{+}\right), 4.38-4.46(\mathrm{~m}$,

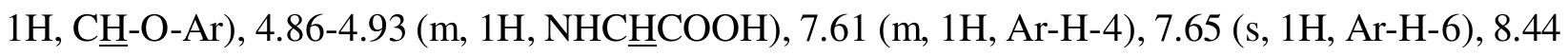
$\left(\mathrm{d}, 1 \mathrm{H},{ }^{3} \mathrm{~J}=8.4 \mathrm{~Hz}, \mathrm{Ar}-\mathrm{H}-3\right), 8.57\left(\right.$ br s, $1 \mathrm{H}, \mathrm{Ha}$ from $\left.\mathrm{NH}_{2}{ }^{+}\right), 8.64\left(\mathrm{~d}, 1 \mathrm{H},{ }^{3} J=7.2 \mathrm{~Hz}\right.$,

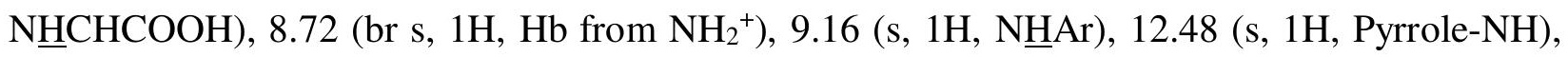
12.57 (br s, $1 \mathrm{H}, \mathrm{COOH}) .{ }^{13} \mathrm{C}$ NMR $\left(100 \mathrm{MHz}, \mathrm{DMSO}-d_{6}\right) /=10.76\left(\right.$ Pyrrole- $^{\left.-\mathrm{CH}_{3}\right)}, 16.93\left(\mathrm{CH}_{3}\right)$, 27.52, 40.99, 48.22, 70.95, 108.61, 110.03, 111.86, 118.58, 118.71, 120.86, 128.99, 129.75, 130.89, 144.71, 156.37, 165.29, 174.25. MS (ESI) $\mathrm{m} / z=481.1\left([\mathrm{M}-\mathrm{H}]^{-}\right)$, HRMS for $\mathrm{C}_{21} \mathrm{H}_{23} \mathrm{Cl}_{2} \mathrm{~N}_{4} \mathrm{O}_{5}$ : calculated 481.1041, found 481.1046. HPLC: Phenomenex Luna C18 column (5 $\mu \mathrm{m}, 4.6 \times 250 \mathrm{~mm}$ ); mobile phase: $10-70 \%$ of acetonitrile in phosphate buffer $(\mathrm{pH}=6.8)$ in 15

$\mathrm{min}, 70 \%$ acetonitrile to $25 \mathrm{~min}$; flow rate $1.0 \mathrm{~mL} / \mathrm{min}$; injection volume: $10 \mathrm{~L} ; \mathrm{t}_{\mathrm{R}}: 11.827 \mathrm{~min}$ $(95.6 \%$ at $280 \mathrm{~nm})$.

\section{(R)-3,4-Dichloro- $N$-(4-((1-hydrazinyl-1-oxopropan-2-yl)carbamoyl)-2-isopropoxyphenyl)-5-} methyl-1H-pyrrole-2-carboxamide (24).

To the solution of $23(0.400 \mathrm{~g}, 0.876 \mathrm{mmol})$ in anhydrous methanol and anhydrous tetrahydrofurane $(1: 1,32 \mathrm{~mL})$ hydrazine monohydrate $(0.42 \mathrm{~mL}, 8.76 \mathrm{mmol})$ was added and the reaction mixture stirred at $68{ }^{\circ} \mathrm{C}$ for $15 \mathrm{~h}$. The obtained suspension was cooled on ice bath, the precipitate filtered off and dried to give $\mathbf{2 4}(0.305 \mathrm{mg})$ as white solid. Yield 77\% (0.305 g); $\mathrm{mp}$ 241-243 ${ }^{\circ} \mathrm{C}$; [ ] $]_{\mathrm{D}}^{25}-33.7$ ( c 0.139, THF). IR (ATR) $=3363,3246,2975,1648,1599,1522,1416$, 1255, 1213, 1115, 976, 749, $646 \mathrm{~cm}^{-1} .{ }^{1} \mathrm{H}$ NMR $(400 \mathrm{MHz}$, DMSO-d 6$) /=1.32-1.38(\mathrm{~m}, 9 \mathrm{H}$, $\mathrm{CH}\left(\mathrm{C}_{3}\right)_{2}, \mathrm{CH}_{3}$ ), 2.24 (s, $3 \mathrm{H}$, Pyrrole- $\mathrm{CH}_{3}$ ), 4.22 (br s, $2 \mathrm{H}, \mathrm{NH}_{2}$ ), 4.47 (quint, $1 \mathrm{H},{ }^{3} \mathrm{~J}=7.2 \mathrm{~Hz}$, $\mathrm{CONHCH}), 4.88\left(\mathrm{spt}, 1 \mathrm{H},{ }^{3} \mathrm{~J}=5.8 \mathrm{~Hz}, \mathrm{C} \underline{\mathrm{H}}\left(\mathrm{CH}_{3}\right)_{2}\right), 7.56\left(\mathrm{dd}, 1 \mathrm{H},{ }^{3} J=8.4 \mathrm{~Hz},{ }^{4} J=1.7 \mathrm{~Hz}, \mathrm{Ar}-\mathrm{H}-\right.$ 5), $7.64\left(\mathrm{~d}, 1 \mathrm{H},{ }^{4} J=1.7 \mathrm{~Hz}, \mathrm{Ar}-\mathrm{H}-3\right), 8.44-8.46$ (m, 2H, Ar-H-6,CONHCH), 9.18 (s, $1 \mathrm{H}, \mathrm{NHNH}_{2}$ ), 9.26 (s, 1H, CONHAr), 11.76 (s, 1H, Pyrrole-NH). ${ }^{13} \mathrm{C}$ NMR (100 MHz, DMSO-d 6 ) / = 10.73 (Pyrrole- $\left.\mathrm{CH}_{3}\right)$, 18.12, $21.77\left(\mathrm{CH}\left(\underline{\mathrm{CH}}_{3}\right)_{2}\right), 21.82\left(\mathrm{CH}\left(\underline{\mathrm{CH}}_{3}\right)_{2}\right), 47.14,71.32\left(\underline{\mathrm{CH}}\left(\mathrm{CH}_{3}\right)_{2}\right), 108.62$, $109.71,111.89,117.89,118.65,120.63,128.89,129.80,131.03,145.08,156.21,165.31$ (Ar$\underline{\mathrm{CONH}}), 171.81$. MS (ESI) $\left.\mathrm{m} / z=454.1([\mathrm{M}-\mathrm{H}]]^{-}\right), \mathrm{HRMS}$ for $\mathrm{C}_{19} \mathrm{H}_{22} \mathrm{Cl}_{2} \mathrm{~N}_{5} \mathrm{O}_{4}$ : calculated 454.1041, found 454.1049. HPLC: Phenomenex Luna C18 column ( $5 \mu \mathrm{m}, 4.6 \times 250 \mathrm{~mm})$; mobile phase: $10-$ $70 \%$ of acetonitrile in phosphate buffer $(\mathrm{pH}=6.8)$ in $15 \mathrm{~min}, 70 \%$ acetonitrile to $25 \mathrm{~min}$; flow rate $1.0 \mathrm{~mL} / \mathrm{min}$; injection volume: $10 \mathrm{~L} ; \mathrm{t}_{\mathrm{R}}: 16.900 \mathrm{~min}(99.0 \%$ at $254 \mathrm{~nm})$.

(R)-3,4-Dichloro- $N$-(2-isopropoxy-4-((1-(5-thioxo-4,5-dihydro-1,3,4-oxadiazol-2yl)ethyl)carbamoyl)phenyl)-5-methyl-1H-pyrrole-2-carboxamide (25). 
To the solution of $24(0.260 \mathrm{~g}, 0.569 \mathrm{mmol})$ in a mixture of 1,4-dioxane and anhydrous dimethylformamide $(1: 2,30 \mathrm{~mL}) 1,1$ çthiocarbonyldiimidazole $(0.254 \mathrm{mg}, 1.43 \mathrm{mmol})$ was added and the reaction mixture was stirred at $100{ }^{\circ} \mathrm{C}$ for $15 \mathrm{~h}$. The solvent was removed under reduced pressure and the crude product was triturated with water and ethanol $(1: 1,8 \mathrm{~mL})$ to afford $25(0.058$ g) as pale yellow solid. Yield $20 \%$ (0.058 g); mp 246-247 ${ }^{\circ} \mathrm{C}$; [. $]_{\mathrm{D}}{ }^{25}-15.1$ (c 0.200 , THF). IR $(\mathrm{ATR})=3356,3255,2978,1646,1597,1512,1492,1415,1264,1213,1108,985,605 \mathrm{~cm}^{-1} .{ }^{1} \mathrm{H}$ NMR (400 MHz, DMSO-d $\left.\mathrm{d}_{6}\right) /=1.35-1.38\left(\mathrm{~m}, 6 \mathrm{H}, \mathrm{CH}\left(\mathrm{C}_{3}\right)_{2}\right), 1.55\left(\mathrm{~d},{ }^{3} J=7.0 \mathrm{~Hz}, \mathrm{CH}_{3}\right) \quad 2.25$ (s, 3H, Pyrrole- $\mathrm{CH}_{3}$ ), 4.86 (spt, $\left.1 \mathrm{H},{ }^{3} J=6.0 \mathrm{~Hz}, \mathrm{C} \underline{\mathrm{H}}\left(\mathrm{CH}_{3}\right)_{2}\right), 5.25$ (quint, $1 \mathrm{H},{ }^{3} J=7.2 \mathrm{~Hz}$, CONHC트), $7.56\left(\mathrm{dd}, 1 \mathrm{H},{ }^{3} J=8.4 \mathrm{~Hz},{ }^{4} J=1.7 \mathrm{~Hz}, \mathrm{Ar}-\mathrm{H}-5\right), 7.61\left(\mathrm{~d}, 1 \mathrm{H},{ }^{4} J=1.7 \mathrm{~Hz}, \mathrm{Ar}-\mathrm{H}-3\right)$, 8.48 (d, $\left.1 \mathrm{H},{ }^{3} J=8.4 \mathrm{~Hz}, \mathrm{Ar}-\mathrm{H}-6\right), 8.99$ (d, ${ }^{3} J=7.2 \mathrm{~Hz}, \mathrm{CON} \underline{\mathrm{HCH}}$ ), 9.27 (s, 1H, CONHAr), 12.46 (s, 1H, Pyrrole-NH), 14.48 (br s, 1H, oxadiazolone-NH). ${ }^{13} \mathrm{C}$ NMR (100 MHz, DMSO-d 6 ) / = $10.76\left(\right.$ Pyrrole- $\left.\left.\mathrm{CH}_{3}\right), 17.16,21.77\left(\mathrm{CH}(\underline{\mathrm{CH}})_{3}\right)_{2}\right), 21.80\left(\mathrm{CH}\left(\mathrm{CH}_{3}\right)_{2}\right), 41.48,71.39\left(\underline{\mathrm{CH}}\left(\mathrm{CH}_{3}\right)_{2}\right)$, 108.63, 109.77, 111.67, 118.02, 118.63, 120.56, 128.07, 129.85, 131.47, 145.25, 156.24, 164.33, 165.20, 177.84. MS (ESI) $\left.\mathrm{m} / z=496.1([\mathrm{M}-\mathrm{H}]]^{-}\right), \mathrm{HRMS}$ for $\mathrm{C}_{20} \mathrm{H}_{20} \mathrm{Cl}_{2} \mathrm{SN}_{5} \mathrm{O}_{4}$ : calculated 496.0615, found 496.0613 .

General procedure I. Synthesis of Compounds 27, 29, 33 and 39 (with 27 as an Example). To a solution of 3,4-dichloro-5-methylpyrrole-2-carboxylic acid $(0.258 \mathrm{~g}, 1.33 \mathrm{mmol})$ in anhydrous dichloromethane $(20 \mathrm{~mL})$, oxalyl chloride $(0.46 \mathrm{~mL}, 5.32 \mathrm{mmol})$ was added dropwise and the solution stirred at $\mathrm{rt}$ for $15 \mathrm{~h}$ under argon atmosphere. The solvent was evaporated under reduced pressure, fresh anhydrous THF $(10 \mathrm{~mL}), 26(0.200 \mathrm{~g}, 1.16 \mathrm{mmol})$ and pyridine $(5 \mathrm{~mL})$ were added and the reaction mixture stirred under argon atmosphere at $\mathrm{rt}$ for $15 \mathrm{~h}$. Solvent was removed under reduced pressure, the residue dissolved in ethyl acetate $(15 \mathrm{~mL})$ and washed with $\mathrm{HCl} 1 \mathrm{M}$ solution $(15 \mathrm{~mL})$ and brine $(2 \times 15 \mathrm{~mL})$. The organic phase was dried over $\mathrm{Na}_{2} \mathrm{SO}_{4}$, filtered and the solvent removed under reduced pressure. The solid was recrystallized from $\mathrm{MeOH}(8 \mathrm{~mL})$ and acetonitrile $(8 \mathrm{~mL})$ to afford $27(0.150 \mathrm{~g})$ as light brown solid.

3,4-Dichloro-5-methyl- $N$-(4-sulfamoylphenyl)- $1 H$-pyrrole-2-carboxamide (27). Light brown solid; yield 37\% (0.150 g); $\mathrm{mp} 290-292{ }^{\circ} \mathrm{C}$. IR (ATR) $=3388,3259,1755,1646,1592$, $1524,1474,1315,1264,1159,886,690,566,536 \mathrm{~cm}^{-1} .{ }^{1} \mathrm{H}$ NMR $\left(400 \mathrm{MHz}\right.$, DMSO- $\left.d_{6}\right):$ / = 2.24 (s, 3H, Pyrrole- $\mathrm{CH}_{3}$ ), 7.30 (s, 2H, NH${ }_{2}$ ), 7.78-7.85 (m, 4H, 4×Ar-H), 9.82 (s, 1H, NHAr). ${ }^{13} \mathrm{C}$ NMR $\left(100 \mathrm{MHz}, \mathrm{DMSO}-d_{6}\right) /=10.79$ (Pyrrole- $\left.\mathrm{CH}_{3}\right), 108.71,112.08,119.19,119.39,126.64,128.51$, 
138.55, 141.56, 157.41. MS (ESI) $\mathrm{m} / z=346.0\left([\mathrm{M}-\mathrm{H}]^{-}\right)$, HRMS for $\mathrm{C}_{12} \mathrm{H}_{10} \mathrm{C}_{12} \mathrm{SN}_{3} \mathrm{O}_{3}$ : calculated 345.9827, found 345.9820. HPLC: Phenomenex Luna C18 column (5 $\mu \mathrm{m}, 4.6 \times 250 \mathrm{~mm})$; mobile phase: $10-70 \%$ of acetonitrile in phosphate buffer $(\mathrm{pH}=6.8)$ in $15 \mathrm{~min}, 70 \%$ acetonitrile to $25 \mathrm{~min}$; flow rate $1.0 \mathrm{~mL} / \mathrm{min}$; injection volume: $10 \mathrm{~L}$; $\mathrm{t}_{\mathrm{R}}: 16.267 \mathrm{~min}(96.5 \%$ at $254 \mathrm{~nm})$.

Methyl 2-(4-nitrophenylsulfonamido)acetate (31) [51]. To a solution of glycine methyl ester hydrochloride $(0.566 \mathrm{~g}, 4.51 \mathrm{mmol})$ and triethylamine $(1.87 \mathrm{~mL}, 13.5 \mathrm{mmol})$ in DCM $(20 \mathrm{~mL}) 4-$ nitrobenzene-1-sulfonyl chloride (30) (1.00 g, $4.51 \mathrm{mmol})$, previously dissolved in DCM (10 mL), was added dropwise at $0{ }^{\circ} \mathrm{C}$. The mixture was allowed to stir at $\mathrm{rt}$ for $12 \mathrm{~h}$. Solvent was removed under reduced pressure, the residue dissolved in ethyl acetate $(15 \mathrm{~mL})$ and washed with $\mathrm{HCl} 1 \mathrm{M}$ solution $(15 \mathrm{~mL})$ and brine $(2 \times 15 \mathrm{~mL})$. The organic phase was dried over $\mathrm{Na}_{2} \mathrm{SO}_{4}$, filtered and the solvent removed under reduced pressure. The obtained solid was recrystallized from $\mathrm{MeOH}(8$ $\mathrm{mL})$ to afford $31(0.840 \mathrm{~g})$ as white crystals. Yield $68 \%(0.840 \mathrm{~g}) ; \mathrm{mp} 130-131{ }^{\circ} \mathrm{C}$. IR (ATR) = $3251,3108,2959,1602,1726,1525,1346,1333,1157,1090,823,734,536 \mathrm{~cm}^{-1} .{ }^{1} \mathrm{H}$ NMR $(400$ MHz, DMSO- $\left.d_{6}\right):$ / = $3.52\left(\mathrm{~s}, 3 \mathrm{H}, \mathrm{OCH}_{3}\right), 3.83\left(\mathrm{~d}, 2 \mathrm{H},{ }^{3} J=6.2 \mathrm{~Hz}, \mathrm{CH}_{2}\right), 8.05\left(\mathrm{~d}, 2 \mathrm{H},{ }^{3} J=8.9 \mathrm{~Hz}\right.$, Ar-H-2,6), 8.41 (d, 2H, $\left.{ }^{3} J=8.9 \mathrm{~Hz}, \mathrm{Ar}-\mathrm{H}-3,5\right), 8.66\left(\mathrm{t}, 1 \mathrm{H},{ }^{3} \mathrm{~J}=6.2 \mathrm{~Hz}, \mathrm{NH}\right)$. MS (ESI) $m / z=273.0$ ([M-H] $]^{-}$, HRMS for $\mathrm{C}_{9} \mathrm{H}_{9} \mathrm{SN}_{2} \mathrm{O}_{6}$ : calculated 273.0187, found 273.0181 .

Methanesulfonamide (36). A solution of methanesulfonyl chloride (35) $(7.97 \mathrm{~mL}, 103 \mathrm{mmol})$ in anhydrous THF $(50 \mathrm{~mL})$ was saturated with gaseous ammonia at $0{ }^{\circ} \mathrm{C}$ for $0.5 \mathrm{~h}$. The resulting white suspension was washed thoroughly with EtOAc, filtered through Celite ${ }^{\circledR}$ and the mother liquor evaporated to give 36 (8.40 g) as white crystals. Yield 85\% (8.40 g); mp 91-92 ${ }^{\circ} \mathrm{C} .{ }^{1} \mathrm{H}$ NMR $\left(400 \mathrm{MHz}, \mathrm{DMSO}-d_{6}\right): /=2.91\left(\mathrm{~s}, 3 \mathrm{H}, \mathrm{CH}_{3}\right), 6.80\left(\mathrm{br} \mathrm{s}, 2 \mathrm{H}, \mathrm{NH}_{2}\right)$. MS (ESI) $m / z=94.0\left([\mathrm{M}-\mathrm{H}]^{-}\right.$ ) .

$N$-(Methylsulfonyl)-4-nitrobenzamide (37) [52]. A mixture of $\mathbf{3 6}(0.769 \mathrm{~g}, 8.08 \mathrm{mmol})$ and 4nitrobenzoyl chloride $(1.50 \mathrm{~g}, 8.08 \mathrm{mmol})$ in anhydrous DCM was cooled to $0{ }^{\circ} \mathrm{C}$. To this suspension triethylamine $(3.41 \mathrm{~mL}, 24.2 \mathrm{mmol})$ was added and the mixture was allowed to stir at $\mathrm{rt}$ for $12 \mathrm{~h}$. The solvent was removed under reduced pressure, EtOAc $(10 \mathrm{~mL})$ and $1 \mathrm{M} \mathrm{HCl}(10$ $\mathrm{mL}$ ) were added to the residue and the phases were separated. The organic phase was washed with brine $(2 \times 10 \mathrm{~mL})$, dried over $\mathrm{Na}_{2} \mathrm{SO}_{4}$, filtered and the solvent removed under reduced pressure. The solid wass triturated with methanol and diethyl ether $(2: 1,8 \mathrm{~mL})$ and filtered off to give 37 $(0.950 \mathrm{~g})$ as white crystals. Yield $48 \%(8.40 \mathrm{~g}) ; \mathrm{mp} 115-118^{\circ} \mathrm{C}\left(116^{\circ} \mathrm{C},[52]\right)$. IR (ATR) = 3251, 3108, 2959, 1602, 1726, 1525, 1346, 1333, 1157, 1090, 823, 734, $536 \mathrm{~cm}^{-1} .{ }^{1} \mathrm{H}$ NMR (400 MHz, 
DMSO- $\left.d_{6}\right) /=3.41\left(\mathrm{~s}, 3 \mathrm{H}, \mathrm{CH}_{3}\right), 8.16\left(\mathrm{~d}, 2 \mathrm{H},{ }^{3} J=8.5 \mathrm{~Hz}, \mathrm{Ar}-\mathrm{H}-2,6\right), 8.36\left(\mathrm{~d}, 2 \mathrm{H},{ }^{3} J=8.5 \mathrm{~Hz}, \mathrm{Ar}-\right.$ $\mathrm{H}-3,5), 12.54$ (br s, $1 \mathrm{H}, \mathrm{NH})$. MS (ESI) $m / z=243.0\left([\mathrm{M}-\mathrm{H}]^{-}\right)$, HRMS for $\mathrm{C}_{8} \mathrm{H}_{7} \mathrm{SN}_{2} \mathrm{O}_{5}$ : calculated 243.0080, found 243.0076 .

1-(4-Nitrophenyl)-1H-tetrazol-5(4H)-one (48) [53]. A mixture of 4-nitrobenzoyl chloride (47) $(2.00 \mathrm{~g}, 10.78 \mathrm{mmol})$ and azidotrimethylsilane $(7.85 \mathrm{~mL}, 59.29 \mathrm{mmol})$ was heated at $90{ }^{\circ} \mathrm{C}$ for 12 $\mathrm{h}$. The mixture was cooled on an ice bath for $0.5 \mathrm{~h}$ and the precipitate was filtered off. The obtained solid was triturated with methanol and diethyl ether $(2: 1,8 \mathrm{~mL})$ and filtered off to give $37(0.870$ g) as light brown solid. Yield $39 \%(0.870 \mathrm{~g})$; mp 214-217 ${ }^{\circ} \mathrm{C}\left(216-217^{\circ} \mathrm{C}\right.$, [53]). IR (ATR) = 3119, 3028, 1716, 1595, 1519, 1332, 1139, 1036, 964, 856, 731, $654 \mathrm{~cm}^{-1}$. ${ }^{1} \mathrm{H}$ NMR (400 MHz, DMSO- $\left.d_{6}\right): /=8.21\left(\mathrm{~d}, 2 \mathrm{H},{ }^{3} \mathrm{~J}=9.2 \mathrm{~Hz}, \mathrm{Ar}-\mathrm{H}-2,6\right), 8.36\left(\mathrm{~d}, 2 \mathrm{H},{ }^{3} \mathrm{~J}=9.2 \mathrm{~Hz}, \mathrm{Ar}-\mathrm{H}-3,5\right), 15.00$ (br s, $1 \mathrm{H}, \mathrm{NH})$. MS (ESI) $m / z=208.1\left([\mathrm{M}+\mathrm{H}]^{+}\right)$.

Diethyl 2-(((3-nitrophenyl)amino)methylene)malonate (52) [54]. 3-Nitroaniline (51) (5.00 g, $36.19 \mathrm{mmol})$ and diethyl ethoxymethylenemalonate $(7.31 \mathrm{~mL}, 36.19 \mathrm{mmol})$ were heated at $90{ }^{\circ} \mathrm{C}$ for $3 \mathrm{~h}$. The reaction mixture was cooled in an ice bath for $1 \mathrm{~h}$ and the precipitate was filtered off. The obtained solid was recrystallized from ethanol $(12 \mathrm{~mL})$ and dried to give $\mathbf{5 2}(7.00 \mathrm{~g})$ as yellow

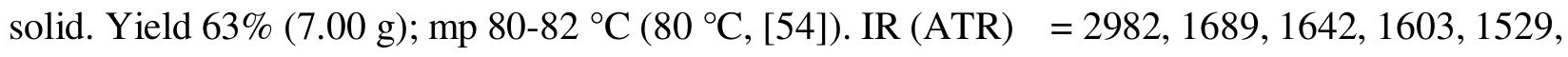
1346, 1241, 1091, 1020, 729, 733, 665, $570 \mathrm{~cm}^{-1}$. ${ }^{1} \mathrm{H}$ NMR (400 MHz, $\left.\mathrm{CDCl}_{3}\right)$ : / = 1.35-1.43 (m, $\left.6 \mathrm{H}, 2 \times \mathrm{CH}_{2} \underline{\mathrm{C}}_{3}\right)$ ), 4.27-4.38 (m, 4H, $\left.2 \times \underline{\mathrm{C}}_{2} \mathrm{CH}_{3}\right), 7.44-7.47$ (m, 1H, Ar-H), 7.56-7.60 (m, 1H, ArH), 7.99-8.03 (m, 2H, Ar-H), $8.54\left(\mathrm{~d}, 1 \mathrm{H},{ }^{3} \mathrm{~J}=12.0 \mathrm{~Hz}, \mathrm{CH}\right), 11.21\left(\mathrm{~d}, 1 \mathrm{H},{ }^{3} J=12.0 \mathrm{~Hz}, \mathrm{NH}\right) . \mathrm{MS}$ (ESI) $m / z=307.1\left([\mathrm{M}-\mathrm{H}]^{-}\right)$, HRMS for $\mathrm{C}_{14} \mathrm{H}_{15} \mathrm{~N}_{2} \mathrm{O}_{6}$ : calculated 307.0935, found 307.0930.

Ethyl 7-nitro-4-oxo-1,4-dihydroquinoline-3-carboxylate (53) [55]. Compound 52 (6.91 g, $22.41 \mathrm{mmol})$ dissolved in diphenyl ether $(25 \mathrm{~mL})$ was refluxed $\left(260{ }^{\circ} \mathrm{C}\right)$ for $2.5 \mathrm{~h}$ with a heating mantle, equipped with a thermometer and an a reflux condenser. The resulting sticky suspension was diluted with acetone and filtered off. The solid was recrystallized from DMSO (15 $\mathrm{mL})$ to afford 53 (4.00 g) as pale yellow solid. Yield 68\% (4.00 g); mp 269-272 ${ }^{\circ} \mathrm{C}$. IR (ATR) = 3093, 2992, 1689, 1634, 1614, 1565, 1515, 1350, 1274, 1195, 1138, 912, 793, $626 \mathrm{~cm}^{-1}$. ${ }^{1} \mathrm{H}$ NMR (400 MHz, DMSO-d6): / = $1.30\left(\mathrm{t}, 3 \mathrm{H},{ }^{3} J=7.1 \mathrm{~Hz}, \mathrm{CH}_{3}\right), 4.24\left(\mathrm{q}, 2 \mathrm{H},{ }^{3} J=7.1 \mathrm{~Hz}, \mathrm{CH}_{2}\right), 8.15(\mathrm{dd}, 1 \mathrm{H}$, ${ }^{3} J=8.8 \mathrm{~Hz},{ }^{4} J=2.0 \mathrm{~Hz}$, Quinoline-H-6), $8.37\left(\mathrm{~d}, 1 \mathrm{H},{ }^{3} \mathrm{~J}=8.8 \mathrm{~Hz}\right.$, Quinoline-H-5), $8.51\left(\mathrm{~d}, 1 \mathrm{H},{ }^{4} \mathrm{~J}\right.$ $=2.0 \mathrm{~Hz}$, Quinoline-H-8), 8.77 (s, 1H, C $\underline{\mathrm{HNH}}$ ), 12.66 (br s, 1H, NH). MS (ESI) $m / z=263.1$ $\left([\mathrm{M}+\mathrm{H}]^{+}\right), \mathrm{HRMS}$ for $\mathrm{C}_{12} \mathrm{H}_{11} \mathrm{~N}_{2} \mathrm{O}_{5}$ : calculated 263.0662, found 263.0668. 
Ethyl 1-ethyl-7-nitro-4-oxo-1,4-dihydroquinoline-3-carboxylate (54) [56]. To a suspension of 53 (2.92 g, $11.1 \mathrm{mmol})$ and potassium carbonate (1.69 g, $12.2 \mathrm{mmol})$ in DMF (75 mL) ethyl bromide $(0.91 \mathrm{~mL}, 12.2 \mathrm{mmol})$ was added. The mixture was stirred at $70{ }^{\circ} \mathrm{C}$ for $12 \mathrm{~h}$. The solvent was removed under reduced pressure, EtOAc $(10 \mathrm{~mL})$ and brine $(10 \mathrm{~mL})$ were added to the residue, the phases were separated, and the organic phase was evaporated under reduced pressure. The solid was triturated with methanol and diethyl ether $(2: 1,10 \mathrm{~mL})$ and filtered off to give $54(1.90 \mathrm{~g})$ as yellow solid. Yield 59\% (1.90 g); mp 220-222 ${ }^{\circ} \mathrm{C}\left(224-226{ }^{\circ} \mathrm{C}\right.$, [56]). IR (ATR) = 3115, 3054, $1674,1642,1600,1564,1523,1453,1347,1316,1209,1134,1095,1011,803,783,737 \mathrm{~cm}^{-1} .{ }^{1} \mathrm{H}$ NMR (400 MHz, DMSO- $\left.d_{6}\right) /=1.30\left(\mathrm{t}, 3 \mathrm{H},{ }^{3} J=7.0 \mathrm{~Hz}, \mathrm{COOCH}_{2} \mathrm{CH}_{3}\right), 1.41\left(\mathrm{t}, 3 \mathrm{H},{ }^{3} J=7.1 \mathrm{~Hz}\right.$, $\left.\mathrm{NCH}_{2} \underline{\mathrm{C}}_{3}\right), 4.26\left(\mathrm{q}, 2 \mathrm{H},{ }^{3} \mathrm{~J}=7.0 \mathrm{~Hz}, \mathrm{COOC}_{2}{ }_{2} \mathrm{CH}_{3}\right), 4.54\left(\mathrm{q}, 2 \mathrm{H},{ }^{3} \mathrm{~J}=7.1 \mathrm{~Hz}, \mathrm{NC}_{2} \mathrm{CH}_{3}\right), 8.22$ $\left(\mathrm{dd}, 1 \mathrm{H},{ }^{3} \mathrm{~J}=8.8 \mathrm{~Hz},{ }^{4} \mathrm{~J}=1.9 \mathrm{~Hz}\right.$, quinoline-H-6), 8.46 (d, $1 \mathrm{H},{ }^{3} \mathrm{~J}=8.8 \mathrm{~Hz}$, quinoline-H-5), 8.55 $\left(\mathrm{d}, 1 \mathrm{H},{ }^{4} \mathrm{~J}=1.9 \mathrm{~Hz}\right.$, quinoline-H-8), $8.85\left(\mathrm{~s}, 1 \mathrm{H}, \mathrm{C}^{\mathrm{HNCH}} \mathrm{CH}_{3}\right) . \mathrm{MS}(\mathrm{ESI}) \mathrm{m} / z=291.1\left([\mathrm{M}+\mathrm{H}]^{+}\right)$, HRMS for $\mathrm{C}_{14} \mathrm{H}_{15} \mathrm{~N}_{2} \mathrm{O}_{5}$ : calculated 291.0976, found 291.0981.

General procedure J. Synthesis of Compounds 45, 55 and 59 (with 45 as an Example). Compound 44 (1.40 g, $4.32 \mathrm{mmol})$ was dissolved in $\mathrm{EtOH}(80 \mathrm{~mL})$ and the mixture was stirred for 30 min under argon atmosphere. $\mathrm{Pd} / \mathrm{C}(0.140 \mathrm{~g})$ was added and the reaction mixture was stirred under hydrogen atmosphere for $3 \mathrm{~h}$. The catalyst was filtered off and the solvent removed under reduced pressure to obtain 45 (1.25 g) as white crystals.

Diethyl 2-(4-aminobenzamido)malonate (45). White crystals; yield 98\% (1.25 g); mp 120-124 ${ }^{\circ} \mathrm{C}\left(122-123{ }^{\circ} \mathrm{C},[57]\right)$. IR (ATR) = 3442, 3346, 3286, 2982, 1736, 1628, 1605, 1502, 1231, 1182 , 1157, 1023, 771, $555 \mathrm{~cm}^{-1}$. ${ }^{1} \mathrm{H}$ NMR (400 MHz, DMSO-d $): /=1.22\left(\mathrm{t}, 6 \mathrm{H},{ }^{3} J=7.1 \mathrm{~Hz}\right.$, $\left.2 \times \mathrm{COOCH}_{2} \mathrm{CH}_{3}\right), 4.12-4.24\left(\mathrm{~m}, 4 \mathrm{H}, 2 \times \mathrm{COOCH}_{2} \mathrm{CH}_{3}\right), 5.24\left(\mathrm{~d}, 1 \mathrm{H},{ }^{3} \mathrm{~J}=7.6 \mathrm{~Hz}, \mathrm{CH}\right), 5.75(\mathrm{~s}, 2 \mathrm{H}$, $\left.\mathrm{NH}_{2}\right), 6.55\left(\mathrm{~d}, 2 \mathrm{H},{ }^{3} \mathrm{~J}=8.7 \mathrm{~Hz}, \mathrm{Ar}-\mathrm{H}-3,5\right), 7.64\left(\mathrm{~d}, 2 \mathrm{H},{ }^{3} J=8.7 \mathrm{~Hz}, \mathrm{Ar}-\mathrm{H}-2,6\right), 8.74\left(\mathrm{~d}, 1 \mathrm{H},{ }^{3} J=\right.$ 7.6 Hz, NH). MS (ESI) $m / z=295.1\left([\mathrm{M}+\mathrm{H}]^{+}\right)$, HRMS for $\mathrm{C}_{14} \mathrm{H}_{19} \mathrm{~N}_{2} \mathrm{O}_{5}$ : calculated 295.1298, found 295.1294.

General procedure K. Synthesis of Compounds 57 and 61 (with 57 as an Example). The starting compound $56(0.105 \mathrm{~g}, 0.24 \mathrm{mmol})$ was suspended in a mixture of $\mathrm{EtOH}$ and 1,4-dioxane (1:1, 20 $\mathrm{mL}) .1 \mathrm{M} \mathrm{NaOH}(0.96 \mathrm{~mL}, 0.96 \mathrm{mmol})$ was added to the mixture which was allowed to stir at $\mathrm{rt}$ for $5 \mathrm{~h}$. The solvent was removed under reduced pressure and $1 \mathrm{M} \mathrm{HCl}(5 \mathrm{~mL})$ was added dropwise to the crude product. A pink colour developed while adding $\mathrm{HCl}$ and the solid was filtered off to give $57(0.060 \mathrm{~g})$ as pink solid. 


\section{7-(3,4-Dichloro-5-methyl-1H-pyrrole-2-carboxamido)-1-ethyl-4-oxo-1,4-}

dihydroquinoline-3-carboxylic acid (57). Pink solid; yield $61 \%(0.060 \mathrm{~g}) ; \mathrm{mp} 268-272{ }^{\circ} \mathrm{C}$. IR $(\mathrm{ATR})=3379,3295,3175,1699,1666,1615,1508,1448,1370,1241,1204,1038,801,800$, $574 \mathrm{~cm}^{-1} .{ }^{1} \mathrm{H}$ NMR $\left(400 \mathrm{MHz}, \mathrm{DMSO}-d_{6}\right): /=1.49\left(\mathrm{t}, 3 \mathrm{H},{ }^{3} \mathrm{~J}=7.0 \mathrm{~Hz}, \mathrm{NCH}_{2} \underline{\mathrm{C}}_{3}\right), 2.26(\mathrm{~s}, 3 \mathrm{H}$,

Pyrrole- $\mathrm{CH}_{3}$ ), $4.53\left(\mathrm{q}, 2 \mathrm{H},{ }^{3} \mathrm{~J}=7.0 \mathrm{~Hz}, \mathrm{NC}_{2} \mathrm{CH}_{3}\right), 7.87\left(\mathrm{dd}, 1 \mathrm{H},{ }^{3} \mathrm{~J}=8.8 \mathrm{~Hz},{ }^{4} \mathrm{~J}=1.6 \mathrm{~Hz}\right.$, quinoline-H-6), 8.35 (d, $1 \mathrm{H},{ }^{3} \mathrm{~J}=8.8 \mathrm{~Hz}$, quinoline-H-5), 8.50 (d, $1 \mathrm{H},{ }^{4} \mathrm{~J}=1.6 \mathrm{~Hz}$, quinoline-H-8), 9.06 (s, 1H, $\underline{\mathrm{HNCH}}_{2} \mathrm{CH}_{3}$ ), 10.28 (s, 1H, NHAr), 12.55 (br s, 1H, Pyrrole-NH), 15.41 (br s, 1H, $\mathrm{COOH}) .{ }^{13} \mathrm{C}$ NMR (100 MHz, DMSO- $\left.d_{6}\right) /=10.81\left(\right.$ Pyrrole- $\left.\mathrm{CH}_{3}\right), 14.12,49.17,106.04,107.74$, 109.07, 113.11, 118.54, 118.64, 120.89, 126.86, 128.83, 139.92, 144.02, 149.18, 157.60, 166.20, 176.91. MS (ESI) $m / z=406.0\left([\mathrm{M}-\mathrm{H}]^{-}\right)$, HRMS for $\mathrm{C}_{18} \mathrm{H}_{14} \mathrm{Cl}_{2} \mathrm{~N}_{3} \mathrm{O}_{4}$ : calculated 406.0356, found 406.0371. HPLC: Phenomenex Luna C18 column $(5 \mu \mathrm{m}, 4.6 \times 250 \mathrm{~mm})$; mobile phase: 10-70\% of acetonitrile in phosphate buffer $(\mathrm{pH}=6.8)$ in $15 \mathrm{~min}, 70 \%$ acetonitrile to $25 \mathrm{~min}$; flow rate 1.0 $\mathrm{mL} / \mathrm{min}$; injection volume: $10 \mathrm{~L}$; $\mathrm{t}_{\mathrm{R}}: 15.443 \mathrm{~min}(98.6 \%$ at $280 \mathrm{~nm})$.

\section{Screening against PAINS}

To evaluate a library of the synthesized compounds against PAINS, all tested compounds were screened against the PAINS filter using the online tool http://www.cbligand.org/PAINS/. All compounds passed the PAINS filter.

\section{ASSOCIATED CONTENT}

Supplementary Information. Full results of antibacterial activity of compounds, detailed experimental procedures, analytical data and NMR spectra of the representative compounds. This material is available free of charge via the internet.

\section{AUTHOR INFORMATION}

\section{Corresponding Author}

*E-mail: nace.zidar@ffa.uni-1j.si. Phone: +386-1-4769578. Fax: +386-1-4258031.

\section{Author Contributions}

The manuscript was written using contributions from all authors. All authors have given approval to the final version of the manuscript. 


\section{Funding Sources}

The work was funded by the Slovenian Research Agency (Grant No. P1-0208), Academy of Finland (Grant No. 277001, 304697 and 312503), grants from the European Research Council H2020-ERC-2014-CoG 648364 - Resistance Evolution (to C.P.), the Wellcome Trust (to C.P.), and GINOP (MolMedEx TUMORDNS) GINOP-2.3.2-15-2016-00020 and GINOP (EVOMER) GINOP-2.3.2-15-2016-00014 (to C.P.), the 'Lendület' Program of the Hungarian Academy of Sciences (to C.P.) and a PhD fellowship from the Boehringer Ingelheim Fonds (to Á.N.).

\section{Conflict of Interest}

The authors declare no conflict of interest including any financial, personal or other relationships with other people or organizations.

\section{ACKNOWLEDGMENT}

This work was supported by the Slovenian Research Agency (Grant No. P1-0208), Academy of Finland (Grant No. 277001, 304697 and 312503), grants from the European Research Council H2020-ERC-2014-CoG 648364 - Resistance Evolution (to C.P.), the Wellcome Trust (to C.P.), and GINOP (MolMedEx TUMORDNS) GINOP-2.3.2-15-2016-00020 and GINOP (EVOMER) GINOP-2.3.2-15-2016-00014 (to C.P.), the 'Lendület' Program of the Hungarian Academy of

Sciences (to C.P.) and a PhD fellowship from the Boehringer Ingelheim Fonds (to Á.N.). We thank Michaela Baran ،oková for the help with biochemical evaluation, and Heli Parviainen, Heidi Mäkkylä and Cristina Carbonell Duacastella for their technical assistance in the antibacterial assays. We thank Nicolas Burton (Inspiralis) for performing the ATPase assay and Prof. Roger Pain for proofreading the manuscript.

\section{REFERENCES}

[1] A. Tagliabue, R. Rappuoli, Changing priorities in vaccinology: antibiotic resistance moving to the top, Front. Immunol. 9 (2018) 1068.

[2] D. Deak, K. Outterson, J.H. Powers, A.S. Kesselheim, Progress in the fight against multidrugresistant bacteria? A review of U.S. Food and Drug Administration-approved antibiotics, 20102015, Ann. Intern. Med. 165 (2016) 363-372. 
[3] F. Collin, S. Karkare, A. Maxwell, Exploiting bacterial DNA gyrase as a drug target: current state and perspectives, Appl. Microbiol. Biotechnol. 92 (2011) 479-497.

[4] M. Oblak, M. Kotnik, T. Solmajer, Discovery and development of ATPase inhibitors of DNA gyrase as antibacterial agents, Curr. Med. Chem. 14 (2007) 2033-2047.

[5] M.K. Kathiravan, M.M. Khilare, K. Nikoomanesh, A.S. Chothe, K.S. Jain, Topoisomerase as target for antibacterial and anticancer drug discovery, J. Enzyme Inhib. Med. Chem. 28 (2013) 419435.

[6] G.S. Bisacchi, J.I. Manchester, A new-class antibacterial-almost. Lessons in drug discovery and development: a critical analysis of more than 50 Years of effort toward ATPase inhibitors of DNA gyrase and topoisomerase IV, ACS Infect. Dis. 1 (2015) 4-41.

[7] A. Naeem, S.L. Badshah, M. Muska, N. Ahmad, K. Khan, The current case of quinolones: synthetic approaches and antibacterial activity, Molecules 21 (2016) 268.

[8] M. Baran ،oková, D. Kikelj, J. Ilaš, Recent progress in the discovery and development of DNA gyrase B inhibitors, Future Med. Chem. 10 (2018) 1207-1227.

[9] G.S. Basarab, P.J. Hill, C.E. Garner, K. Hull, O. Green, B.A. Sherer, P.B. Dangel, J.I. Manchester, S. Bist, S. Hauck, F. Zhou, M. Uria-Nickelsen, R. Illingworth, R. Alm, M. Rooney, A.E. Eakin, Optimization of pyrrolamide topoisomerase II inhibitors toward identification of an antibacterial clinical candidate (AZD5099), J. Med. Chem. 57 (2014) 6060-6082.

[10] D.R. Haydon, L.G. Czaplewski, N.J. Palmer, D.R. Mitchell, J.F. Atherall, C.R. Steele, T. Ladduwahetty, Antibacterial compositions, Int. Pat. Appl. WO2007148093 A1.

[11] I.A. Yule, L.G. Czaplewski, S. Pommier, D.T. Davies, S.K. Narramore, C.W.G. Fishwick, Pyridine-3-carboxamide-6-yl-ureas as novel inhibitors of bacterial DNA gyrase: Structure based design, synthesis, SAR and antimicrobial activity, Eur. J. Med. Chem. 86 (2014) 31-38.

[12] N. Zidar, H. Macut, T. Tomaši ،, M. Brvar, S. Montalvão, P. Tammela, T. Solmajer, L. Peterlin Maši ،, J. Ilaš, D. Kikelj, $N$-Phenyl-4,5-dibromopyrrolamides and $N$-Phenylindolamides as ATP Competitive DNA Gyrase B Inhibitors: Design, Synthesis, and Evaluation, J. Med. Chem. 58 (2015) 6179-6194.

[13] N. Zidar, T. Tomaši „, H. Macut, A. Sirc, M. Brvar, S. Montalvão, P. Tammela, J. Ilaš, D. Kikelj, New $N$-phenyl-4,5-dibromopyrrolamides and $N$-Phenylindolamides as ATPase inhibitors of DNA gyrase, Eur. J. Med. Chem. 117 (2016) 197-211. 
[14] M. Durcik, P. Tammela, M. Baran ‘oková, T. Tomaši ‘, J. Ilaš, D. Kikelj, N. Zidar, Synthesis and evaluation of $N$ (phenylpyrrolamides as DNA gyrase B Inhibitors, ChemMedChem 13 (2017) 186-198.

[15] M. Durcik, D. Lovison, Ž. Skok, C.D. Cruz, P. Tammela, T. Tomaši „, D.B. Tiz, G. Draskovits, Á. Nyerges, C. Pál, J. Ilaš, L.P. Maši ،, D. Kikelj, N. Zidar, New N-phenylpyrrolamide DNA gyrase B inhibitors: Optimisation of efficacy and antibacterial activity, Eur. J. Med. Chem. (2018) 117132.

[16] L.W. Tari, X. Li, M. Trzoss, D.C. Bensen, Z. Chen, T. Lam, J. Zhang, S.J. Lee, G. Hough, D. Phillipson, S. Akers-Rodriguez, M.L. Cunningham, B.P. Kwan, K.J. Nelson, A. Castellano, J.B. Locke, V. Brown-Driver, T.M. Murphy, V.S. Ong, C.M. Pillar, D.L. Shinabarger, J. Nix, F.C. Lightstone, S.E. Wong, T.B. Nguyen, K.J. Shaw, J. Finn, Tricyclic GyrB/ParE (TriBE) inhibitors: a new class of broad-spectrum dual-targeting antibacterial agents, PLoS ONE, 8 (2013) e84409. [17] T. Tomaši ،, S. Katsamakas, Z. Hodnik, J. Ilaš, M. Brvar, T. Solmajer, S. Montalvão, P. Tammela, M. Banjanac, G. Ergovi,, M. Anderluh, L. Peterlin Maši ‘, D. Kikelj, Discovery of 4,5,6,7-tetrahydrobenzo[1,2- $d]$ thiazoles as novel DNA gyrase inhibitors targeting the ATP-binding site, J. Med. Chem. 58 (2015) 5501-5521.

[18] G.S. Basarab, J.I. Manchester, S. Bist, P.A. Boriack-Sjodin, B. Dangel, R. Illingworth, B.A. Sherer, S. Sriram, M. Uria-Nickelsen, A.E. Eakin, Fragment-to-hit-to-lead discovery of a novel pyridylurea scaffold of ATP competitive dual targeting type II topoisomerase inhibiting antibacterial agents, J. Med. Chem. 56 (2013) 8712-8735.

[19] M.F. Richter, B.S. Drown, A.P. Riley, A. Garcia, T. Shirai, R.L. Svec, P.J. Hergenrother, Predictive compound accumulation rules yield a broad-spectrum antibiotic, Nature 545 (2017) 299304.

[20] P. Lassalas, B. Gay, C. Lasfargeas, M.J. James, V. Tran, K.G. Vijayendran, K.R. Brunden, M.C. Kozlowski, C.J. Thomas, A.B. Smith, D.M. Huryn, C. Ballatore, Structure property relationships of carboxylic acid isosteres, J. Med. Chem. 59 (2016) 3183-3203.

[21] M.A.J. Duncton, R.B. Murray, G. Park, R. Singh, Tetrazolone as an acid bioisostere: application to marketed drugs containing a carboxylic acid, Org. Biomol. Chem. 14 (2016) 93439347. 
[22] F.F. Fleming, L. Yao, P.C. Ravikumar, L. Funk, B.C. Shook, Nitrile-containing pharmaceuticals: efficacious roles of the nitrile pharmacophore, J. Med. Chem. 53 (2010) $7902-$ 7917.

[23] M.A.J. Duncton, R. Singh, A one-pot synthesis of tetrazolones from acid chlorides: understanding functional group compatibility, and application to the late-stage functionalization of marketed drugs, Org. Biomol. Chem. 14 (2016) 9338-9342.

[24] J.J. Li, Gould-Jacobs reaction, in: J.J. Li (Ed.) Name reactions: a collection of detailed mechanisms and synthetic applications, Springer Berlin Heidelberg, Berlin, Heidelberg, 2009, pp. 263-265.

[25] GOLD Suite v5.4 is available from The Cambridge Crystallographic Data Centre, 12 Union Road, Cambridge, CB2 1EZ (UK), http://www.ccdc.cam.ac.uk

[26] T. Pinter, S. Jana, R.J.M. Courtemanche, F. Hof, Recognition properties of carboxylic acid bioisosteres: anion binding by tetrazoles, aryl sulfonamides, and acyl sulfonamides on a calix[4]arene scaffold, J. Org. Chem. 76 (2011) 3733-3741.

[27] P.H. Olesen, The use of bioisosteric groups in lead optimization, Curr. Opin. Drug. Discov. Devel. 4 (2001) 471-478.

[28] J.Y. Le Questel, M. Berthelot, C. Laurence, Hydrogen(bond acceptor properties of nitriles: a combined crystallographic and ab initio theoretical investigation, J. Phys. Org. Chem. 13 (2000) 347-358.

[29] S.T. Murphy, H.L. Case, E. Ellsworth, S. Hagen, M. Huband, T. Joannides, C. Limberakis, K.R. Marotti, A.M. Ottolini, M. Rauckhorst, J. Starr, M. Stier, C. Taylor, T. Zhu, A. Blaser, W.A. Denny, G.-L. Lu, J.B. Smaill, F. Rivault, The synthesis and biological evaluation of novel series of nitrile-containing fluoroquinolones as antibacterial agents, Bioorg. Med. Chem. Lett. 17 (2007) 2150-2155.

[30] M. Remko, Molecular structure, pKa, lipophilicity, solubility and absorption of biologically active aromatic and heterocyclic sulfonamides, J. Mol. Structure-Theochem. 944 (2010) 34-42.

[31] J. Larsson, J. Gottfries, L. Bohlin, A. Backlund, Expanding the ChemGPS chemical space with natural products, J. Nat. Prod. 68 (2005) 985-991.

[32] F. Richter Michelle, J. Hergenrother Paul, The challenge of converting Gram-positive-only compounds into broad-spectrum antibiotics, Ann. N. Y. Acad. Sci. (2018) 1-21. 
[33] M.A. Kuenemann, L.M. Bourbon, C.M. Labbe, B.O. Villoutreix, O. Sperandio, Which threedimensional characteristics make efficient inhibitors of protein-protein interactions?, J. Chem. Inf. Model. 54 (2014) 3067-3079.

[34] B.D. Bax, P.F. Chan, D.S. Eggleston, A. Fosberry, D.R. Gentry, F. Gorrec, I. Giordano, M.M. Hann, A. Hennessy, M. Hibbs, J.Z. Huang, E. Jones, J. Jones, K.K. Brown, C.J. Lewis, E.W. May, M.R. Saunders, O. Singh, C.E. Spitzfaden, C. Shen, A. Shillings, A.J. Theobald, A. Wohlkonig, N.D. Pearson, M.N. Gwynn, Type IIA topoisomerase inhibition by a new class of antibacterial agents, Nature 466 (2010) 935-951.

[35] J. Larsson, J. Gottfries, L. Bohlin, A. Backlund, Expanding the ChemGPS chemical space with natural products, J. Nat. Prod. 68 (2005) 985-991.

[36] D. Benedetto Tiz, D. Kikelj, N. Zidar, Overcoming problems of poor drug penetration into bacteria: challenges and strategies for medicinal chemists, Expert Opin. Drug Discov. (2018) 1-11. [37] J. Larsson, J. Gottfries, S. Muresan, A. Backlund, ChemGPS-NP: tuned for navigation in biologically relevant chemical space, J. Nat. Prod. 70 (2007) 789-794.

[38] PerkinElmer Informatics, Inc. http://www.perkinelmer.com/Product/chemoffice-professionalchemofficepro

[39] Kylebank Software Ltd, Ayrshire, UK, https://www.teraplot.com

[40] A. Daina, O. Michielin, V. Zoete, SwissADME: a free web tool to evaluate pharmacokinetics, drug-likeness and medicinal chemistry friendliness of small molecules, Sci. Rep. 7 (2017) 42717. [41] I. Moriguchi, S. Hirono, Q. Liu, I. Nakagome, Y. Matsushita, Simple method of calculating octanol/water partition coefficient, Chem. Pharm. Bull. 40 (1992) 127-130.

[42] J.S. Delaney, ESOL: $\$ Estimating Aqueous Solubility Directly from Molecular Structure, J. Chem. Inf. Comput. Sci. 44 (2004) 1000-1005.

[43] A. Nyerges, B. Csorgo, I. Nagy, B. Balint, P. Bihari, V. Lazar, G. Apjok, K. Umenhoffer, B. Bogos, G. Posfai, C. Pal, A highly precise and portable genome engineering method allows comparison of mutational effects across bacterial species, Proc. Natl. Acad. Sci. U S A 113 (2016) 2502-2507.

[44] T. Baba, T. Ara, M. Hasegawa, Y. Takai, Y. Okumura, M. Baba, K.A. Datsenko, M. Tomita, B.L. Wanner, H. Mori, Construction of Escherichia coli K-12 in-frame, single-gene knockout mutants: the Keio collection, Molecular Systems Biology, 2 (2006) 1-11. 
[45] Methods for Dilution Antimicrobial Susceptibility Tests for Bacteria that Grow Aerobically, Approved Standard. In., 9th ed edn. Wayne, Pennsylvania 2012.

[46] G. Garg, H. Zhao, B.S. Blagg, Design, synthesis, and biological evaluation of ring-constrained novobiocin analogues as Hsp90 C-terminal inhibitors, ACS Med. Chem. Lett. 6 (2015) 204-209. [47] Promega Corporation, Madison, WI, https://worldwide.promega.com/.

[48] R. Pingaew, P. Mandi, C. Nantasenamat, S. Prachayasittikul, S. Ruchirawat, V. Prachayasittikul, Design, synthesis and molecular docking studies of novel $\mathrm{N}$-benzenesulfonyl1,2,3,4-tetrahydroisoquinoline-based triazoles with potential anticancer activity, Eur. J. Med. Chem. 81 (2014) 192-203.

[49] M. Budovska, M. Pilatova, L. Varinska, J. Mojzis, R. Mezencev, The synthesis and anticancer activity of analogs of the indole phytoalexins brassinin, 1-methoxyspirobrassinol methyl ether and cyclobrassinin, Bioorg. Med. Chem. 21 (2013) 6623-6633.

[50] G. Jones, P. Willett, R.C. Glen, A.R. Leach, R. Taylor, Development and validation of a genetic algorithm for flexible docking, J. Mol. Biol. 267 (1997) 727-748.

[51] B. Palakurthy Nani, D. Dev, S. Rana, C. Nadimpally Krishna, B. Mandal, Sulfonamide synthesis via oxyma(R (sulfonates - compatibility to acid sensitive groups and solid(phase peptide synthesis, Eur. J. Org. Chem. 2013 (2013) 2627-2633.

[52] M.N. Soltani Rad, A. Khalafi-Nezhad, Z. Asrari, S. Behrouz, Highly efficient one-pot synthesis of $\mathrm{N}$-acylsulfonamides using cyanuric chloride at room temperature, Synthesis 2010 (2010) 2599-2603.

[53] N.G. Egorova, T.V. Artamonova, A. Hrabalek, G.I. Koldobskii, Reactions of 5Methylsulfinyl-1-(4-nitrophenyl)tetrazole with $N$-nucleophiles, Russ. J. Org. Chem. 41 (2005) 1399-1401.

[54] A.K.S. Bhujanga Rao, A.S. Radhakrishna, C.G. Rao, B.B. Singh, S.P. Bhatnagar, An improved procedure for the preparation of ethyl . -carbethoxy- -(arylamino)acrylates, Org. Prep. Proced. Int. 20 (1988) 93-95.

[55] F.d.C.S. Boechat, C.Q. Sacramento, A.C. Cunha, F.S. Sagrillo, C.M. Nogueira, N. FintelmanRodrigues, O. Santos-Filho, C.S. Riscado, L.d.S.M. Forezi, L.V. Faro, L. Brozeguini, I.P. Marques, V.F. Ferreira, T.M.L. Souza, M.C.B.V. de Souza, 1,2,3-Triazolyl-4-oxoquinolines: A feasible beginning for promising chemical structures to inhibit oseltamivir-resistant influenza A and B viruses, Bioorg. Med. Chem. 23 (2015) 7777-7784. 
[56] H. Agui, T. Komatsu, T. Nakagome, Studies on quinoline derivatives and related compounds. II. Synthesis of 5(substituted 1(ethyl(1,4(dihydro(( oxol( quinolinecarboxylic acid, J. Heterocycl. Chem. 12 (1975) 557-563.

[57] W.B. Wright, D.B. Cosulich, M.J. Fahrenbach, C.W. Waller, J.M. Smith, M.E. Hultquist, Analogs of pteroylglutamic acid. IV. Replacement of glutamic acid by other amino acids, J. Am. Chem. Soc. 71 (1949) 3014-3017. 